\title{
BAIXA PRODUTIVIDADE DO MILHO COMO CONSEQUENNCIA DA TOMADA DE DECISÃO SOB CONDIÇŌES DE RISCO NA AGRICULTURA
}

\section{ANGELA REGINA PIRES E PÉRES}

\author{
Orientador: JOAQUIM JOSÉ DE CAMARGO ENGLER
}

Dissertação apresentada à Escola Superior de Agricultura "Luiz de Queiroz", da Universidade de São Paulo, para obtenção do título de Mestre em Economia Agrária.

PIRACICABA

Estado de São Paulo - Brasil

Dezembro - 1981 
BAIXA PRODUTIVIDADE DO MILHO COMO CONSEQUÊNCIA DA TOMADA DE DECISÃO SOB CONDIÇÕES DE RISCO NA AGRICULTURA

ANGELA REgina PIRES E PÉRES

Orientador: JOAQUIM JOSÉ DE CAMARGO ENGLER

Dissertação apresentada à Escola Superior de Agricultura "Luiz de Queiroz", da Universidade de São Paulo, para obtenção do título de Mestre em Economia Agrāria.

P I RACI CABA

Estado de São Paulo - Brasil

Dezembro, 1981 
A

meus pais, esposo e filhos. 


\section{AGRADEC IMENT OS}

0 autor deseja expressar seu profundo agradecimento às seguintes pessoas e instituições:

À Fundação de Amparo à Pesquisa do Estado de São Paulo (FAPESP) por ter proporcionado bolsa de estudo durante a elaboração deste trabalho;

Ao Professor Joaquim Josē de Camargo Engler pela orientação e por sua amizade;

Aos Professores Zilda Paes de Barros Mattos, José . Ferreira de Noronha e Fernando Curi Péres pelas valiosas sugestões of $\underline{e}$ recidas;

Aos demais Professores do Departamento de Economia e Sociologia Rural da ESALQ que direta ou indiretamente colaboraram com esta pesquisa;

Ao Dr. Fernando L: Garagorry, da EMBRAPA, por seus inestimāveis préstimos no processamento de dados;

À Srta. Ana Assunção Beltrame, Sra. Djanira Bortolan Forti e Sr. Pedro Scardua pela colaboração prestada;

Aos Colegas do Curso pelo ambiente de camaradagem propiciado. 
I $\quad N \quad D \quad I \quad C \quad E$

Página

LISTA DE TABELAS $\ldots \ldots \ldots \ldots \ldots \ldots \ldots \ldots \ldots \ldots \ldots \ldots \ldots \ldots \ldots \ldots$

LISTA DE FIGURAS $\ldots \ldots \ldots \ldots \ldots \ldots \ldots \ldots \ldots \ldots \ldots \ldots \ldots \ldots \ldots \ldots$

RESUMO $\ldots \ldots \ldots \ldots \ldots \ldots \ldots \ldots \ldots \ldots \ldots \ldots \ldots \ldots \ldots \ldots \ldots \ldots \ldots \ldots$

SUMMARY $\ldots \ldots \ldots \ldots \ldots \ldots \ldots \ldots \ldots \ldots \ldots \ldots \ldots \ldots \ldots \ldots \ldots \ldots \ldots \ldots$

1. INTRODUÇÃO $\ldots \ldots \ldots \ldots \ldots \ldots \ldots \ldots \ldots \ldots \ldots \ldots \ldots \ldots \ldots \ldots \ldots \ldots$

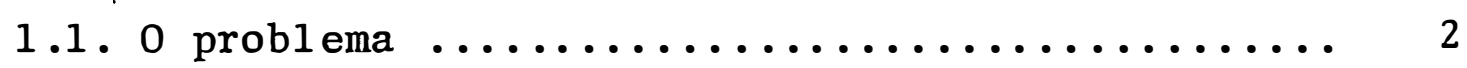

1.1.1. A cultura do milho dentro da atual política agrícola ................ 2

1.1.2. A baixa produtividade do milho ....... 7

1.1.3. Explicações alternativas para a bai xa produtividade da terra na produção de milho .................. 9

1.1.3.1. Hipótese da concentração ..... 10

1.1.3.2. Hipótese da "dualidade tẹc nológica" .............. 12

1.1.3.3. 0 milho como "cultura de subsistência" ............ 14

1.1.4. Sumário do problema $\ldots \ldots \ldots \ldots \ldots \ldots \ldots$ 
1.2. Hipóteses a serem testadas .............. 16

1.3. Objetivos ...................... 20

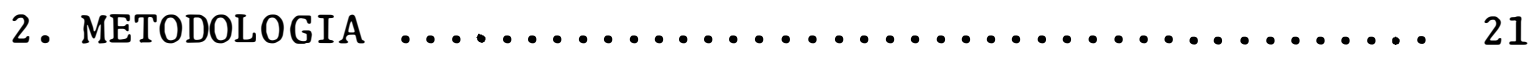

2.1. 0 modelo de maximização de 1 ucro $\ldots \ldots \ldots \ldots \ldots 23$

2.1.1. Limitações do modelo ............ 30

2.2. 0 modelo de expectativa de preços $\ldots \ldots \ldots \ldots \ldots 32$

3. A REgiÃo, dAdOS E PROCEDIMENTO .............. 35

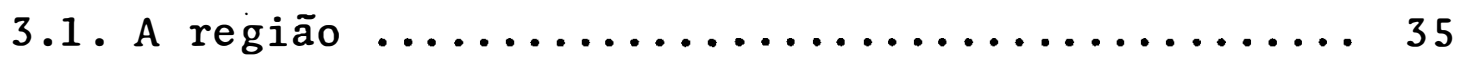

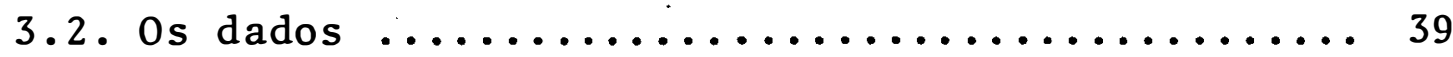

3.3. 0 procedimento adotado ............... 42

4. ATIVIDADES E RESTRIÇÕES USADAS NO MODELO DE PROGRAMAÇÃO $\ldots \ldots \ldots \ldots \ldots \ldots \ldots \ldots \ldots \ldots \ldots \ldots \ldots$

4.1. Expectativa de preços ................ 49

4.2. Atividades, recursos requeridos e função objetivo $\ldots \ldots \ldots \ldots \ldots \ldots \ldots \ldots \ldots \ldots \ldots \ldots \ldots$

4.3. Restrições (R.H.S.) .................. 70

5. RESUltados E CONCLUSõES ........................ 74

5.1 . Introdução de $\operatorname{risco} \ldots \ldots \ldots \ldots \ldots \ldots \ldots \ldots \ldots \ldots$

5.2. A fronteira eficiente ................ 77 
5.3. Conclusões e recomendações ............... 91

LITERATURA CITADA $\ldots \ldots \ldots \ldots \ldots \ldots \ldots \ldots \ldots \ldots \ldots . \ldots 3$

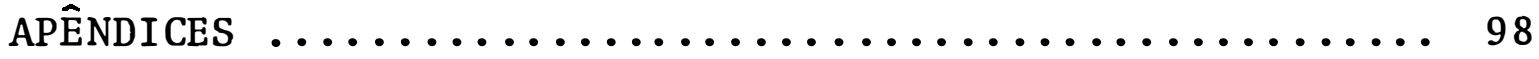


vi i

LISTA DE TABELAS

Página

TABELA 1. Preços Médios Recebidos pelos Produtores Paulistas de Milho ................ 13

TABELA 2. Área de Quatro Culturas Anuais na Região de Ribeirão Preto, São Paulo, 1966-1975 .... 37

TABELA 3. Número de Unidades de Produção Agrícola que Compõe a Amostra em cada Levantamento nos Cinco Municípios da Micro-Região Homogênea Serra de Jaboticabal ......... 41

TABELA 4. Cronograma Físico e Financeiro de 1 A 1 queire de Café ( 2.400 covas), nos 24 Anos a Partir de sua Formação, com Controle de "Ferrugem", Região de Ribeirão Preto, SP, a Preços Médios do Ano Agrícola 19.78/

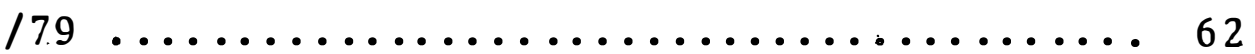

TABELA 5. Cronograma Físico e Financeiro de 1 A1queire de Laranja (5.000 pés) Durante o Período de Planejamento de 24 Anos, a Par tir de sua Formação, com Tecnologia Reco mendada Para a Região de Ribeirão Preto, SP, a Preços Médios do Ano Agrícola 1978/79 .... 64. 
TABELA 6. Cronograma Físico e Financeiro de 1 Alqueire de Pastagem Artificial Durante o Horizonte de Planejamento de 5 Anos a Partir de sua Formação, Região de Ribei rão Preto, SP, Ano Agrícola 1978/79 ........ 65

TABELA 7. Cómposię̧ão do Rebantio de Suinos Tipo Banha, Despesas Requeridas e Retorno Anual - $1978 / 79 \ldots \ldots \ldots \ldots \ldots \ldots \ldots \ldots \ldots \ldots . \ldots \ldots 6 . \ldots \ldots$

TABELA 8. Composição do Rebanho de Cria de Bovinos, Despesas Requeridas e Retorno Anual - $1978 / 79$

TABELA 9. Crédito para Custeio, 1978/79, Ribeirão Preto, SP

TABELA 10. Estimativa da Receita Real da Bovinocul tura de Corte Através de um Coeficiente de Correção de Preço para o Período $1974-1978 \ldots \ldots \ldots \ldots \ldots \ldots \ldots \ldots \ldots \ldots \ldots \ldots \ldots \ldots \ldots \ldots \ldots \ldots \ldots \ldots$

TABELA 11. Estimativa da Receita Real para Suinos Tipo Banha para o Período 1974-1978 ... 79 
TABELA 12. Combinação das Atividades Correspondentes aos Diversos Pontos da Fronteira Eficiente para o Nível de Disponibilidade de Capital de $\operatorname{Cr} \$ 100.000,00$. Ano Agrícola

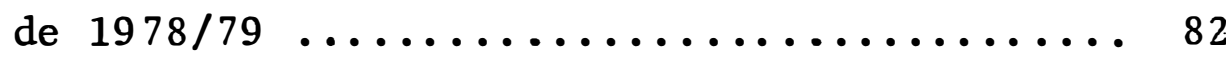

TABELA 13. Combinação das Atividades Correspondentes aos Diversos Pontos da Fronteira Eficiente para o Nível de Disponibilidade de Capital de Cr $\$ 200.000,00$. Ano Agrícola de $1978 / 79 \ldots \ldots \ldots \ldots \ldots \ldots \ldots \ldots \ldots . \ldots . \ldots . \ldots . \ldots$

TABELA 14. Combinação das Atividades Correspondentes aos Diversos Pontos da Fronteira Eficiente para o Nível de Disponibilidade de Ca pital de $\operatorname{Cr} \$ 200.000,00$. Atividade Suínos Forçada em 4 Unidades Animais. Ano Agrícola de $1978 / 79 \ldots \ldots \ldots \ldots \ldots \ldots \ldots . \ldots 6$

TABELA 15. Matriz dos Coeficientes de Correlação das Margens Brutas das Diversas Atividades Consideradas no Mode1o. Período 1974-78 ... 90 
LISTA DE FIGURAS

Página

FIGURA 1. Produtividade do Milho no Estado de São Paulo, Região Nordeste e Brasil, de $1933 / 37$ a $1973 / 75 \ldots \ldots \ldots \ldots \ldots \ldots \ldots \ldots$

FIGURA 2. Representação Hipotética da Fronteira Eficiente ........................ 25

FIGURA 3. "Pacotes" Tecnológicos de Produção ........ 27

FIGURA 4. A Divisão Regional Agrícola (DIRA) de Ribeirão Preto e a Área de Amostra ....... 38

FIGURA 5. As Fronteiras Eficientes Para os Níveis de Disponibilidade de Capital de 100 e 200. Mil Cruzeiros ................. 84 
RESUMO

BAIXA PRODUTIVIDADE DO MILHO COMO CONSEQUÊNCIA DA TOMADA DE DECISĀO SOB CONDIÇŌES DE RISCO NA AGRICULTURA

ANGELA REgINA PIRES E PÉRES

Orientador: JOAQUIM J. DE CAMARGO ENGLER

0 presente estudo faz parte do projeto interdis diplinar de pesquisa - Projeto Milho II - que vem sendo desenvolvido deste 1978, pelo Departamento de Economia e Sociologia Rural, juntamente com outros Departamentos da ESALQ - USP (Gené tica, Fitotecnia e Fitopatologia), visando desenvolver varieda des e técnicas mais produtivas, assim como estudar o processo mais eficiente de transferir aos agricultores a tecnologia dis ponível, ou determinar a razão da resistência dos agricultores à adoção das novas tecnologias.

Embora resultados experimentais estejam indican do que o milho pode ser economicamente cultivado a níveis altos de produtividade, as médias de produção por unidade de área, no Brasil e mesmo em São Paulo, persistem a níveis mito baixos.

A hipótese fundamental do trabalho é de que a produtividade do milho continua báixa devido a incertezas asso ciadas à produção e à variações de preço. Outra hipótese é a de que devido aos baixos níveis de disponibilidade de capital 
próprio os agricultores tem preferido as culturas de subsistên cia e o cultivo do milho com tecnologia correspondente a níveis mais baixos de produtividade.

O estudo desenvolve e testa um modelo de compor tamento dos agricultores que incorpora elementos de risco na produção, além de considerar, explicitamente, no processo de decisão, expectativas quanto à inflação. Os tipos de risco considerados são os de preço e de produtividade. o modelo ana lítico baseia-se na anālise de atividade, desenvolvido por Koopmans (Activity Analysis), com modificações sugeridas por Hazell para incorporar risco, sem necessidade de usar programa ção quadrātica.

Alêm do objetivo específico de estudar as causas da persistência de baixas produtividades na cultura do mi1ho, o estudo pretende contribuir para o entendimento do processo de tomada de decisão dos agricultores de São Paulo.

A ārea escolhida para o estudo é a região agrícola de Ribeirão Preto, Estado de São Paulo.

O nível de disponibilidade de capital operacional foi fixado em valores crescentes a partir de 10 mil cruze $\underline{i}$ ros atē que não sobrasse terra não utilizada. Com o capital de giro disponível no início do período de $200 \mathrm{mil}$ cruzeiros, foi rejeitada a hipótese de que os agricultores cultivam milho de baixa produtividade como uma maneira de reduzir risco. 
xiii

O autor sugere que se trabalhe com outros casos (dados) para aumentar a confïança no teste. Sugere, também, que este tipo de anālise seja desenvolvido num modelo dinâmico que incorpore outras formas de risco. 


\title{
SUMMARY
}

LOW YIELD IN CORN PRODUCTION AS A CONSEQUENCE OF HEDGIND AGAINST RISK TO FARMER'S DECISION MAKING PROCESS

\author{
By ANGELA REGINA PIRES E PERES \\ Adviser JOAQUIM J.C. ENGLER
}

The purpose of the study was to test the hypothesis that farmers resistance to the use of new technologies in corn production is due to the way they hedge against risk of price and yield variations. The testing procedure followed the work developed by Hazell (MOTAD) based on an approximation to Markowitz's E - V analysis. The region studied was the "Microregião Homogênea Serra de Jaboticabal" of Ribeirão Preto, SP.

The hypothesis was rejected. This means that hedging against risk probably is not impairing the adoption of high yield technologies for corn production. 
1. I NTROD UÇĀO

Este estudo visa determinar a razão da resistên cia dos agricultores à adoção de novas tecnologias. Desenvolve e testa um modelo analítico baseado na "E-V Analysis" e incorpora condições de risco e inflação ao processo de tomada de decisão dos agricultores.' Os tipos de risco considerados são os de preço e de produtividade, resultados da incapacidade do agricultor de prever o preço do produto e a quantidade produzida.

0 primeiro capítulo descreve o problema comparando-o a outros estudos, levanta as hipóteses a serem téstadas e indica o objetivo do estudo. A parte metodológica é de senvolvida no segundo capítulo. Ao terceiro, cabe uma descrí ção geral da área pesquisada, dos dados coletados e do procedí mento utilizado. No quarto capítulo são descritas as ativida des e restrições usadas no modelo de programação linear. 0 ca pítulo final analisa os resultados, explicando como o risco é introduzido no modelo e como são derivadas as fronteiras efi- 
cientes. As conclusões e recomendações para outros trabalhos estão tambēm incluídas neste capítulo.

1.1. 0 problema

1.1.1. A cultura do milho dentro da atual política agrícola

Ao setor agrícola cabe papel importante no cha mado modelo brasileiro de desenvolvimento. De um lado o setor deverá suprir a população de alimentos baratos e fornecer matérias primas à indústria a preços compativeis com a polítí ca de combate à inflação. De outro, o setor deverá ser o principal responsável pelo necessário superavit do balanço co mercial, se o país quiser reduzir sua divida com o exterior. Quanto ao setor exportador, os produtos agrícolas tem uma importância maior do que a exportação de manufaturados. 0 mais difícil desafio é representado pela produção de alimentos com maior produtividade dos fatores de produção (MENDONÇA DE BARROS e GRAHAM, 1978). Segundo estes autores um dos proble mas a serem enfrentados pela politica comercial brasileira é a ampliação tanto quanto possível do número de produtos expor tados. E, neste caso, desponta o milho, por ser um exemplo de produto com bom potencial de vendas externas ainda nãoapro. veitado, extendendo as vantagens da exportação a: um número maior de produtores. 
O milho é um caso especial de produto que con- . corre, simultaneamente; para a consecução dos dois objetivos mencionados. Uma parte importante da produção nacional é consumida na própria fazenda, diretamente ou como insumo na produção animal, e, o restante é, princịpalmente, destinado à crescente indústria de ração ou mesmo à exportação direta (FUN DAÇÃo GETULIO VARGAS, 1978) . Como um insumo na produção de carnes de aves e suínos, o milho é componente importante na formação do custo destes produtos-chave no combate à inflação. Por outro lado, a perspectiva de contínuo crescimento das exportações de frangos, requer produções de milho cada vez maiores e a preços baixos, de modo a garantir a competiti. vidade do produto. A elasticidade-renda da demanda por carnes é relativamente àta o que indica que o país demandará, com o desenvolvimento, cada dia maiores quantidades de milho.

Para se atingir o desenvolvimento do setor agri cola, o mercado externo é de grande valia porque dá ao país a possibilidade de experimentar mudanças tecnológicas causando um deslocamento da curva da oferta para a direita. HOMEM DE MELO (1974) indica que o Brasil teria condições para expandir a produção de milho e, consequentemente, sua exportação, for necendo subsídios à política governamental e indica também que, com um aumento na produção deste produto se daria uma alteração na direção de uma mais eficiente alocação de recursos. Num outro trabalho (1979), o mesmo autor classificou o 
milho no grupo dos produtos intermediários juntamente com o amendoim, porque são produtos que poderiam ser de mercado externo mas, não aparecem na pauta de exportação todos os anos e nem sempre em quantidades significativas em relação à produ ção nacional.

Outros, aspectos sobre o milho no Brasil são mencionados por THOMPSON e SCHUH (1978): 0 milho tem pouca importância relativa nas exportações brasileiras apesar de ser um produto agrícola bastante importante em termos de área geo gráfica e número de pessoas envolvidas em sua produção. As instalações para armazenagem deste produto, no país, são bastante limitadas porisso existe pouca variação de estoques de um ano para outro. Os resultados de seu trabalho indicaram que a demanda interna e a oferta de curto e longo prazo do milho são inelásticas ${ }^{1}$.: Completando, os autores sugerem que, mesmo sendo baixas as elasticidade-preço da oferta e da deman da interna, se o governo quisesse, poderia expandir o excesso exportável de milho através de uma política de preços de exportação (taxa de câmbio de equilíbrio e eliminação das cotas de exportação).

A figura 1 mostra a produtividade do milho no período $1933 / 1975$ em termos de São Paulo, Nordeste e Brasil

1 SEVER e VEIGA F̊ (1977) também mostraram ofertas relativamente inelásticas de curto e longo prazo para feijão e milho quando analisaram alguns produtos agrícolas em termos de área cultivada em relação à variação de preços. 
como um todo. Pela figura, pode-se verificar que houveram importantes aumentos dé produtividade no estado de São Paulo a partir de 1953 até o fim do período. No entanto, os níveis de produtividade no Nordeste declinaram sucessivamente e chegaram a cerca de $700 \mathrm{~kg} / \mathrm{ha}$, considerados muito baixos.

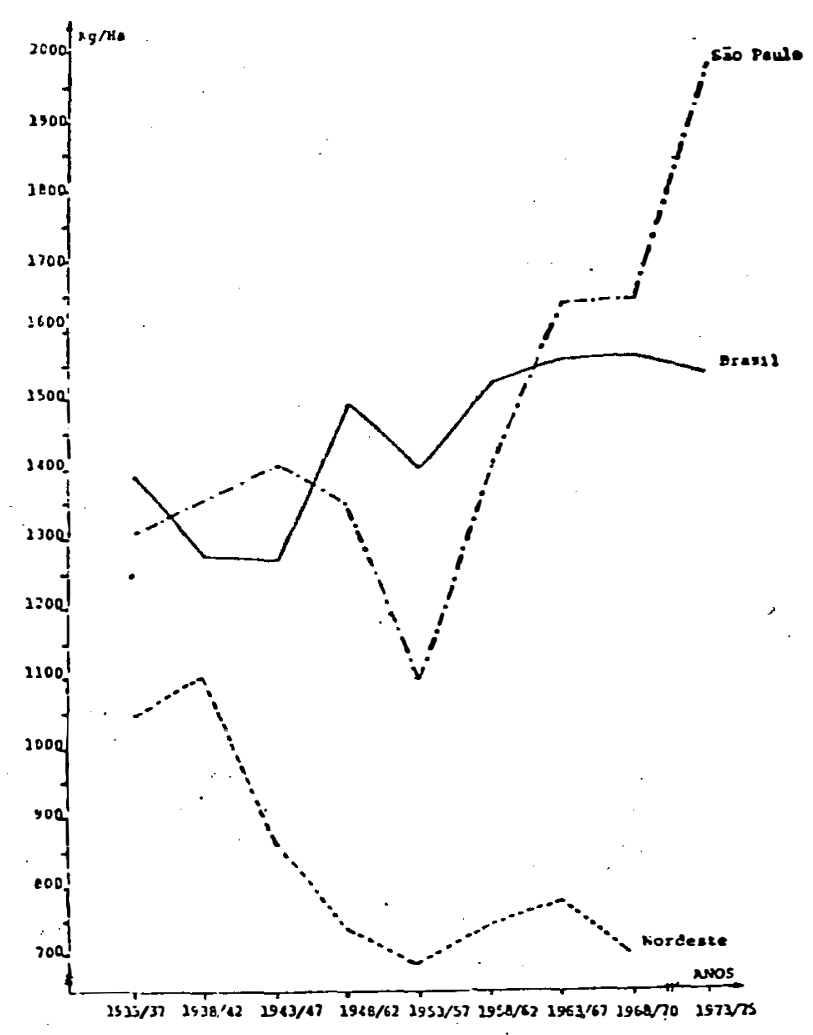

Fig. 1. Produtividade do Milho no Estado de São Paulo, Região Nordeste e Brasil, de 1933/37 a 1973/75.

Fonte: Pastore et alii (1976).

A Região Sul - Sudeste foi responsável porr $81,1 \%$ da produção de milho no Brasil, no quinquênio 1970/74 (dados primários, FIBGE) • Embora o estado de São Paulo (e Santa Ca tarina também) apresente produtividade da terra $(2.000 \mathrm{~kg} / \mathrm{ha})$ 
superior à média do país, sua produtividade perfaz somente cerca de $40 \%$ da produtividade média dos Estados Unidos, ou cer ca de $50 \%$ da produtividade média da China Continental. Como esta baixa produtividade tem se mantido relativamente constan te nos últimos anos, o necessário aumento da produção nos pró ximos anos teria que vir do crescimento da fronteira agrícola, o que implicaria em altos investimentos em infraestrutura, al tos custos de transportes e/ou possíveis problemas ecológicos de exploração da Amazônia. Dentro deste quadro, o milho pro vavelmente sairá perdendo se continuar como uma cultura volta da ao mercado interno.

Pode-se ainda acrescentar que desde 1979 está sendo solicitada à agricultura produzir álcool para substituir petróleo (gasolina). A viabilidade a curto prazo da ex pansão agrícola de alimentos consumidos no mercado interno, produtos de exportação e substitutos do petróleo, foi recente mente questionada por HOMEM DE MELO (1980) pois, um provável conflito pode surgir entre estes três objetivos:

"Dadas as condições atuais de produtividade, o setor agrícola teria que apresentar uma taxa de expansão da área cultivada total da ordem de 7,5 - 8,0\% para permitir a realização destes três objetivos. Essa taxa de expansão da área, para se ter uma idéia de sua magnitude, é o dobro da ta xa historicamente observada no Brasil. Adiciona1mente, esse crescimento de área é uma condição ne cessária mas não inteiramente suficiente para $\bar{a}$ plena realização dos objetivos atuais da política agrícola. Isto porque outros instrumentos terão que ser introduzidos para garantir o uso de terras na produção de alimentos, já que os exportáveis e 
a cana-de-açúcar podem crescer a taxas mais eleva das que as contempladas".

\subsubsection{A baixa produtividade do milho}

O milho é produzido tanto por agricultores que empregam técnicas modernas como por produtores tradicionais.

As instituições responsāveis pela pesquisa agronômica no estado de São Paulo tem oferecido aos agricultó res, principalmente através da Coordenadoria de Assistência Técnica e Integral (CATI), pacotes tecnológicos que, se adota dos, deveriam aumentar a produtividade da terra no cultivo do milho. No entanto, a produtividade da terra na cultura do milho continua baixa .

Em São Paulo, provavelmente, encontra-se o melhor sistema de informações tecnológicas para o agricultor. Alguns produtos são produzidos com tecnologias razoavelmente sofisticadas, indicando que estas informações tem chegado aos agricultores. Em trabalho que verifica as condições responsáveis pela produtividade da pesquisa agrícola no Brasil (PAS TORE et alii, 1976), foram examinados seis importantes produtos comerciais, três deles produtos de exportação e três de consumo doméstico - entre estes últimos, o milho. Foi mostrado que os gastos de pesquisa com o milho foram substanciais quando comparados ao caso do arroz e do feijão e também que, 
a produtividade só aumentou nos campos experimentais. Neste sentido, MENDONÇA DE BARROS e GRAHAM (1978) mostraram que:

"o crescimento da produção no sul do País se faz muito mais em direção aos produtos exportáveis; a produtividade cresce de forma importante apenas no Estado de São Paulo mas, em geral, ela so tem crescido no grupo de produtos exportáveis; nos anos recentes a produtividade no setor doméstico (alimentos) tem declinado".

Ao comparar as culturas do milho e do algodão no estado de São Paulo HOMEM DE, MELO (1977) verificou que a situação do milho era bem mais séria do que a do algodão, não só quanto aos níveis de rendimentos médios obtidos em São Paulo e no Brasil como, também, quando comparada à de outros países. Mas as produtividades médias destas duas culturas em estações experimentais, hã vārios anos são bastante altas quando comparados às de outros países grandes produtores. Nestas estações de pesquisa foram desenvolvidas variedades mais produtivas para os dois produtos desde os anos 1930 - 1940 . Pode-se notar, ainda, neste trabalho, que somente os produtores de algodão conseguiram captar as mudanças tecnológicas. Foram usadas as seguintes variáveis explicativas: relação de preços produto / fertilizantes, ārea cultivada, tecnologia e clima. 0 estudo lembra que na década de sessenta e início de setenta verificaram-se vārias distorções no mercado desse produto tais como a supervalorização da taxa cambial brasilei ra, a política tarifária e de contingenciamento na importação 
de fertilizantes, as periódicas restrições às exportações des te cereal, o deficiente sistema de comercialização externa e os efeitos negativos dos programas agrícolas de países desenvolvidos. Támbém foi estimado que o preço-real do nutriente fósforo no período 1967 - 72 foi em média 49\% mais elevado para os agricultores paulistas em relação aos americanos enquan to que para o nitrogênio o seu preço real foi $28 \%$ mais elevado.

Sabe-se ainda que, o Instituto Agronômico de Campinas, desenvolveu desde 1932, um extenso programa de pesquisa para o milho com a produção de sementes híbridas e sintéticas conseguindo ainda o aprimoramento de inúmeras práticas culturais. São Paulo foi a terceira região do mundo a plantar.o milho híbrido (PASTORE et alii, 1976). As indicações acima mencionadas destacam o problema que se pretende es tudar: como explicar a persistência da baixa produtividade na cultura do milho quando se sabe que a tecnologia necessária para o aumento da produtividade existe à disposição do agricultor?

1.1.3. Explicações alternativas para a baixa produtividade da terra na produção de milho

A baixa produtividade da terra na cultura do milho ainda não encontrou explicação convincente. Esta pesquisa constitui-se em um esforço adicional no sentido de elucidar este fenômeno. 
Embora hipóteses tenham sido levantadas, para explicar a persistênciá destas baixas produtividades, elas não tem sido suficientemente robustas no sentido de resistir aos testes de confronto com a realidade.

Algumas destas hipóteses são discutidas a seguir.

1.1.3.1. Hipótese da concentração sugerida por PASTORE et alii (1976)

Considerando o café, a cana-de-açúcar e o algo dão como produtos de exportação e, o arroz, o feijão è o mi1 ho como produtos de consumo doméstico e partindo da hipótese da inovação induzida de HAYAMI e RUTTAN (1971) segundo a qual a pesquisa agrícola tende a responder a forças de mercado, os autores acima citados verificaram as condições responsáveis pe la produtividade da pesquisa agrícola no Brasil, analisando a relação entre o desenvolvimento da mesma e a dinâmica do se tor agrícola. Foram adicionadas algumas condições relevantes às suposições básicas do modelo para que esta anālise pudesse ser feita. Dentre estas condiçōes cabe destacar o grau de concentração geogrāfica do produto. Segundo os auto res esta condição exerce efeitos importantes sobre as possibí lidades de desenvolvimento da pesquisa agrícola. Mas, o caso do milho não parece ser bem explicado por esta hipótese, pois, esta cultura ocupa a primeira posição em termos de área 
de cultivo e ocorre sem grandes áreas de concentração da produção. Deveria, portánto, merecer pouca atenção dos pesquisadores. Isso, no entanto, não tem acontecido de fato. Os resultados experimentais indicam niveis altos de produtividade e o milho é uma cultura que, em termos globais, tem recebi do um tratamento privilegiado durante toda a história da pesquisa agrícola no Brasil. Entretanto a média de produção desta cultura obtida pelos agricultores, por unidade de ärea continua sendo bastante baixa.

Os autores comentam ainda, em relação ao milho que ..."é possível que a dispersão geográfica e a relativa de sorganização dos produtores, intermediários e consumidores criem importantes imperfeições de mercado"... impedindo as possibilidades de interação eficiente entre agricultores e pesquisadores. Foi tambēm feita uma interessante observação sobre uma relativa concentração regional no chamado cinturão constị tuído pelo sudeste de Goiás, o Triângulo Mineiro e a Mogiana Paulista, onde a produtividade do milho vem alcançando niveis elevados, com uma média situada entre 3.600 e $3.800 \mathrm{~kg} / \mathrm{ha}$ (FIPE/MA) .

Como foi dito anteriormente, o caso do milho não é bem explicado por esta hipótese. As informações sugerem que o padrão de pesquisa do milho é desenvolvido e pode ser comparado ao utilizado no caso dos produtos de exportação existindo ou não concentração geográfica. 
1.1.3.2. Hipótese da "dualidade tecnológica" de PAIVA (1968 e 1971)

PAIVA discutiu o problema da expansão de técnicas modernas e o mecanismo de autocontrole no processo de adoção e expansão destas técnicas. Segundo o autor, este mecanismo impõe séria limitação à melhoria do nível médio de pró dutividade do setor agrícola estabelecendo uma situação de dua lidade tecnológica nos países em desenvolvimento. Dualidade tecnológica, característica dos países em desenvolvimento, sig nifica que as técnicas modernas são adotadas por alguns agricultores, mas ficam restritas a uma pequena porcentagem deles. Sempre que houver adoção de uma nova tecnologia por determina do número de produtores, haverá, em contrapartida, uma queda de preços (do produto e da mão-de-obra), queda essa que deses timula outros agricultores de adotā-1as.

A explicação baseada na hipótese dualista pare ce ter sido válida até 1972. A partir desta data, entretanto, a limitação da explicação dualista prendeu-se ao fato de que os preços dos produtos agrícolas estiveram crescendo mais do que os dos outros setores. Pela tabela 1 e tomando-se co mo base os preços reais do milho em 1968 - $1970=100$, podese notar uma clara tendência de crescimento dos preços durante este período, com uma excessão de 1975 a 1977 .

Portanto este fato vem enfrequecer uma das im- 
Tabela 1. Preços Médios Recebidos pelos Produtores paul istas de Milho - Cr\$/saca de $60 \mathrm{~kg}$

\begin{tabular}{lccc}
\hline ANO & $\begin{array}{c}\text { Preço corrente } \text { a } \\
\text { Cr\$ / unidade }\end{array}$ & $\begin{array}{c}\text { Preço real } \text { fr } \$ / \text { unidade } \\
\text { Indice de preços } \\
\text { reais de milho } \\
1968-1970=100\end{array}$ \\
\hline 1968 & 6,60 & 11,87 & 85,69 \\
1969 & 10,40 & 15,00 & 108,28 \\
1970 & 12,20 & 14,69 & 106,04 \\
1971 & 14,30 & 14,30 & 103,23 \\
1972 & 18,80 & 16,07 & 116,00 \\
1973 & 27,40 & 20,35 & 146,90 \\
1974 & 32,90 & 18,99 & 137,08 \\
1975 & 48,10 & 21,74 & 156,93 \\
1976 & 59,30 & 18,97 & 136,94 \\
1977 & 68,60 & 15,37 & 110,95 \\
1978 & 131,30 & 21,22 & 153,18 \\
1979 & 196,00 & 20,58 & 148,56 \\
1980 & 418,50 & 22,14 & 159,82 \\
\hline
\end{tabular}

a) Fonte: Informações Econômicas, I.E.A. (diversos núme-

b/ Os preços médios são expressos em cruzeiros de 1971 e obtidos através do Indice " 2 " da Conjuntura Econômica, FGV, tendo como base $1965-1967=100$. 
plicações do modelo sugerido por PAIVA, de que o preço dos produtos agrícolas devériam cair com o aumento da produção causado pelas inovações tecnológicas adotadas.

1.1.3.3. O milho como "cultura de subsistência"

A hipótese de que a baixa produtividade é devida à condição de cultura de subsistência foi discutida por vá rios autores recentemente, mas ainda não foi suficientemente testada em suas implicações.

HOMEM DE MELO (1977) identificou o milho como uma cultura de subsistência e devido às condições de baixa lu cratividade dessa cultura, chegou à conclusão de que os agricultores não se sentem estimulados a uma maior utilização da tecnologia jā desenvolvida pelas instituições de pesquisa.

Ao estudar algumas propostas para discussão so bre o problema da renda instável do grupo de pequenos produto res e do abastecimento do mercado interno de produtos básicos, PÉRES (1979) chegou a conclusões semelhantes às de HOMEM DE MELO (1977). Tomando como base os seguintes fatores: politicas governamentais de combate à inflação, reduzidas possibi lidades de produção de outros produtos, necessidade de grande diversificação da produção para redução de risco, resultados tecnológicos positivos para as culturas não básicas, custo de oportunidade da mão-de-obra dos pequenos produtores geralmen- 
te baixo (regiões minifundiārias), escassez de capital, etc, Péres sugere que os pequenos agricultores teriam que se vol tar para culturas de "sobrevivência" ou de "subsistência", pois as culturas mais rentáveis estariam fora do alcance deles.

Alguns dados vem completar a justificativa para a hipótese citada acima:

"Em termos de Brasil e da produção de alimentos bá sicos, é importante notar que, em 1975 , os estabelecimentos com menos de 50 hectares produziam 73\% do total do feijão, $79 \%$ do de mandioca, $63 \%$ do de milho e 43\% do de arroz" (HOMEM DE MELO, 1980).

Embora o milho como produto interno de alimentação seja produzido, na sua maior parte, pelos pequenos produtores, as sugestões de que a baixa produtividade deriva da situação de produção para subsistência precisam ser melhor testadas.

\subsubsection{Sumário do problema}

Embora resultados experimentais estejam indicando que o milho pode ser "economicamente" cultivado a níveis altos de produtividade as médias de produção por unidade de área, no Brasil e mesmo em São Paulo, persistem a níveis considerados baixos. Como explicar a defasagem entre a produtividade potencial e a atual ?

Se for abandonada a hipótese de que a não ado- 
ção da tecnologia moderna de produção de milho é devida a deficiências do sistema de difusão de tecnologias, então é preciso procurar outras explicações para o comportamento dos agri cultores.

As hipóteses levantadas anteriormente, parecem nao ser suficientes para explicar a persistência dessa baixa produtividade.

\subsection{Hipóteses a serem testadas}

O presente estudo baseia-se na hipótese de que a produtividade da cultura do milho continua baixa devido a incertezas ${ }^{2}$ associadas à produção e à variações de preço.

A segunda hipótese levantada pelo estudo é a de que o plantio do milho estaria sendo feito em épocas diferentes da recomendada devido à necessidade de uso dos fatores (máquinas, mão-de-obra, principalmente) em outras culturas na queles periodos criticos (problemas de "timing").

A terceira e ūltima hipótese baseia-se no fato de que os produtores de milho com baixos níveis de disponibilidade de capital próprio tem preferido as culturas de subsis tência e ao cultivo do milho com tecnologia correspondente a

\footnotetext{
2 Os termos incerteza ou risco, são usados como sinônimos.
} 
níveis menores de produtividade.

0 processo de tomada de decisões pelos agricul tores brasileiros (que ocorre, em geral, em condições de alto grau de risco) não tem merecido a necessária atenção dos pesquisadores nacionais. 0 uso do conceito tradicional de "racionalidade econômica", que impõe maximização de lucros, tem sido incapaz de explicar a persistência dos baixos indices de produtividade na agricultura. 0 alto grau de incerteza característico da agricultura brasileira requer um tratamento especial ao risco na construção de um modelo de comportamento dos agricultores (SCHUH, 1974).

Altos graus de risco impõem na agricultura,cus tos ou ineficiências cujo conhecimento pode ajudar na compreen são das baixas produtividades. A necessidade de diversifica ção da produção, como medida de redução de riscos, impede o setor de utilizar, plenamente, as vantagens advindas da especialização (especialmente a divisão do trabalho). Por outro lado, a incerteza acerca de rendimentos futuros tende a reduzir a disposição dos agricultores de realizar investimentos cujo pagamento deve ser efetuado em períodos posteriores. Assim, as razões da adoção de determinados pacotes tecnológicos devem ser baseados na interação entre as diversas cultú ras em uma propriedade ou empresa.

Um exemplo elucidativo desta interação pode ser dado pela possibilidade de redução de riscos de preços quando 
o agricultor cultiva milho e produz porcos magros (para serem cevados). Os agricultores sabem que, em geral, quando o pre ço do milho está baixo, o preço do porco magro (especialmente o porco tipo banha produzido em regiões menos desenvolvidas) estará alto e vice-versa. Cultivando-se ambas (suinocultura e maysicultura) pode-se, praticamente, eliminar os riscos de perdas devido a baixos preços dos produtos.

A produção de milho è parte de um processo que envolve alto risco, portanto a diversificação de culturas tor na-se necessária como maneira de reduzir riscos. Entre as possíveis consequências desta diversificação, estão as perdas decorrentes da não especialização do trabalho, tanto ao níve1 de trabalho manual ou mecânico quanto ao nível de administração. A necessidade do uso de fatores escassos de produção, simultâneamente, em diversas culturas, pode levar o agricultor a usā-los em quantidades menores que as requeridas por va riedades de altas produtividades numa determinada cultura, por que seu uso produziria retornos maiores em outras culturas.

\footnotetext{
"Por ser uma cultura 'marginal', isto é, por ser considerada uma cultura de segunda classe pelos agricultores, o milho tende a ser uma atividade residual dentro das propriedades agrícolas em termos de utilização da terra, do capital e dos recursos humanos disponiveis. Com isso a época de plantio normalmente não é obedecida, sendo an tecipado ou relegado para o final do período recomendado. Igualmente, tanto os tratos culturais como a colheita nem sempre seguem as recomendações" (PASTORE et alii, 1976).
} 
Os produtores agrícolas brasileiros parecem en frentar um racionamentó interno e externo de capital. Se isto estiver acontecendo tanto a unidade familiar produtiva quanto a economia sacrificam crescimento potencial (SCHUH, 1974).

As inovações tecnológicas requerem maiores usos de capital. Os pequenos agricultores impõem a si mesmos um racionamento de capital, assim chamado racionamento interno, que é responsável por certa aversão à contratação de débitos o que está de acordo com o "princípio da aversão absoluta ao risco decrescente". Quanto maior a relação débitos / ativos de um agricultor, maior o risco de perda do seu próprio capital, ou de ver ameaçada a sobrevivência de sua familia, no ca so de pequenos produtores. 0 segundo tipo, ou seja, o racio namento externo de capital, é imposto aos pequenos agricultores pelos bancos e por outros emprestadores devido aos desestímulos a pequenos empréstimos que a política de juros subsidiados do crédito rural tende a provocar (PÉRES, 1979).

Em outras palavras, na presença de risco tanto os produtores quanto os emprestadores se protegem contra os mesmos. Os fazendeiros impõem racionamento de crédito a si mesmos como uma regra contra risco e como meio de continuar flexível. Por outro lado, os bancos impõem racionamento de crédito às unidades produtoras como um meio de proteger a si mesmos contra o mesmo risco (SCHUH, 1974). 
1.3. Objetivos

O objetivo deste estudo é identificar a relação entre a baixa produtividade da terra na cultura do milho no estado de São Paulo e o processo de tomada de decisão na elaboração dos planos de produção dos agricultores. Pretende-se, com isto, explicar a persistência da baixa produtivida de da terra nesta cultura, desafiando a pesquisa agronômica e os serviços de extensão rural do País.

Para se conseguir o objetivo geral mencionado, pretende-se, especificamente, simular o processo decisório do agricultor usando para isto um modelo que, explicitamente, considere as diversas fases de produção de cada cultura, com as respectivas exigências de fatores de produção, e as intera ções entre estes processos produtivos. Risco e inflação serão incorporados ao modelo de comportamento a ser construído. 0 modelo de comportamento dos agricultores será baseado na técnica de programação linear. 


\section{METODOLOGIA}

Como foi estabelecido no capítulo 1 , o objetí vo geral do presente trabalho foi identificar, através do estudo do comportamento do agricultor frente a situações de risco, as causas da persistência da baixa produtividade na cultura do milho no estado de São Paulo.

Para atingir este objetivo foi usada uma metodologia que simula o processo de decisão do agricultor, cons $\underline{i}$ derando as diversas fases de produção de cada cultura e incor porando os efeitos do risco e da inflação.

0 método matemātico da Programação Linear foi escolhido para este estudo porque é uma técnica que permite trabalhar simultaneamente com um grande número de variāveis. Tem sido um instrumento muito eficiente na anālise econômica e na administração rural.

Foi elaborada uma matriz de coeficientes técni cos para representar a "propriedade típica" da região. Atra 
vés de uma análise estática comparativa foi estudado o comportamento do agricultór sob condições diversas de disponibilidade de capital operacional. Foi construído um modelo de expectativa de preços nominais para os diversos produtos com o qual se determinou: uma taxa de variação nos preços que incorpora os efeitos da inflação. Este procedimento tem a van tagem de permitir capturar-se o efeito da transferência de re cursos através de subsídios do crédito na forma de taxas de juros nominais inferiores à inflação esperada. 0 modelo è baseado na pressuposição de que o preço esperado é função dos recentes ( $n$ últimos anos) níveis de inflação verificados no País.

Este capítulo está dividido em duas partes. Em primeiro lugar é apresentado o modelo de comportamento do agricultor pressupondo o objetivo de maximização de lucro. Logo em seguida é discutido o enfoque da Média-Variância ("E-V analysis") no modelo de decisão sob condições de risco. Pode-se verificar que, a solução do modelo simples de maximização de lucro é só um caso particular do modelo mais geral E - V (PÉRES, 1976). Algumas limitações da "E-V analysis" são também discutidas.

A segunda parte consta da apresentação do mode 10 de expectativa de preços. 
2.1. 0 modelo de maximização de lucro.

0 modelo a ser desenvolvido parte da chamada análise de atividade (Activity Analysis) desenvolvido por KOOPMANS (1971) .

$\mathrm{Na}$ sua forma mais simples, pode ser simboliza-

do por

$$
\begin{array}{cl}
\text { Maximizar } & \pi=c^{\prime} \mathrm{x} \\
\text { sujeito a } & \mathrm{Ax} \leqq \mathrm{b} \\
\mathrm{e} & \mathrm{x} \geqq 0
\end{array}
$$

onde,

$\pi$ é o lucro ;

c é um vetor (coluna) do qual o elemento $c_{j}$ é a margem bruta $^{1}$ correspondente à atividade $\mathbf{j}$;

$x$ é um vetor (coluna) do qual o elemento $x_{j}$ é o nível da atividade $\mathbf{j}$;

A é uma matriz mxn da qual o elemento $a_{i j}$ corresponde ao coeficiente técnico do fator $i$ por unidade de pro dução da atividade $\mathbf{j}$;

b é um vetor (coluna) do qual o elemento $b_{i}$ é o nível

1 Margem bruta é a remuneração aos fatores fixos. 


$$
\begin{aligned}
& \text { da restrição } \mathbf{i} ; \\
& \mathbf{j}=1,2, \ldots, \mathrm{n} \text { sao as } \text { atividades; } \\
& \mathbf{i}=1,2, \ldots, \mathrm{m} \text { são as } \text { restrições. }
\end{aligned}
$$

Pode-se, facilmente, introduzir "risco" neste modelo, através do uso de uma aproximação linear - MOTAD, sugerido por Hazell - ao enfoque desenvolvido por MARKOWITZ (1952) :chamado de Média-Variância (E-V analysis). 0 modelo desenvolvido por Markowitz considera duas características de cada atividade (culturas, no caso presente): a média $(\pi)$ e a variância $\left(\sigma^{2}\right)$ dos retornos ou lucros-brutos .

Graficamente (Fig. 2), o enfoque da média-variância permite a construção de uma relação entre retorno (1 $\underline{u}$ cro) e risco (medidos, respectivamente, pelo valor esperado e variância) correspondentes às diversas combinações de cultura, numa propriedade. Quando esta relação entre risco e retorno é tal que a cada unidade de risco incorrido correspon de o máximo de retorno ou, a mesma coisa dita de outra maneira, a cada nível de retorno corresponde o menor nível de risco necessário para se atingir aquele retorno, então esta rela ção é chamada "fronteira eficiente". A cada ponto localizado na fronteira eficiente, corresponde um plano de cultivo para a empresa.

o uso da variância $\left(\sigma^{2}\right)$, explicitamente, no mo 


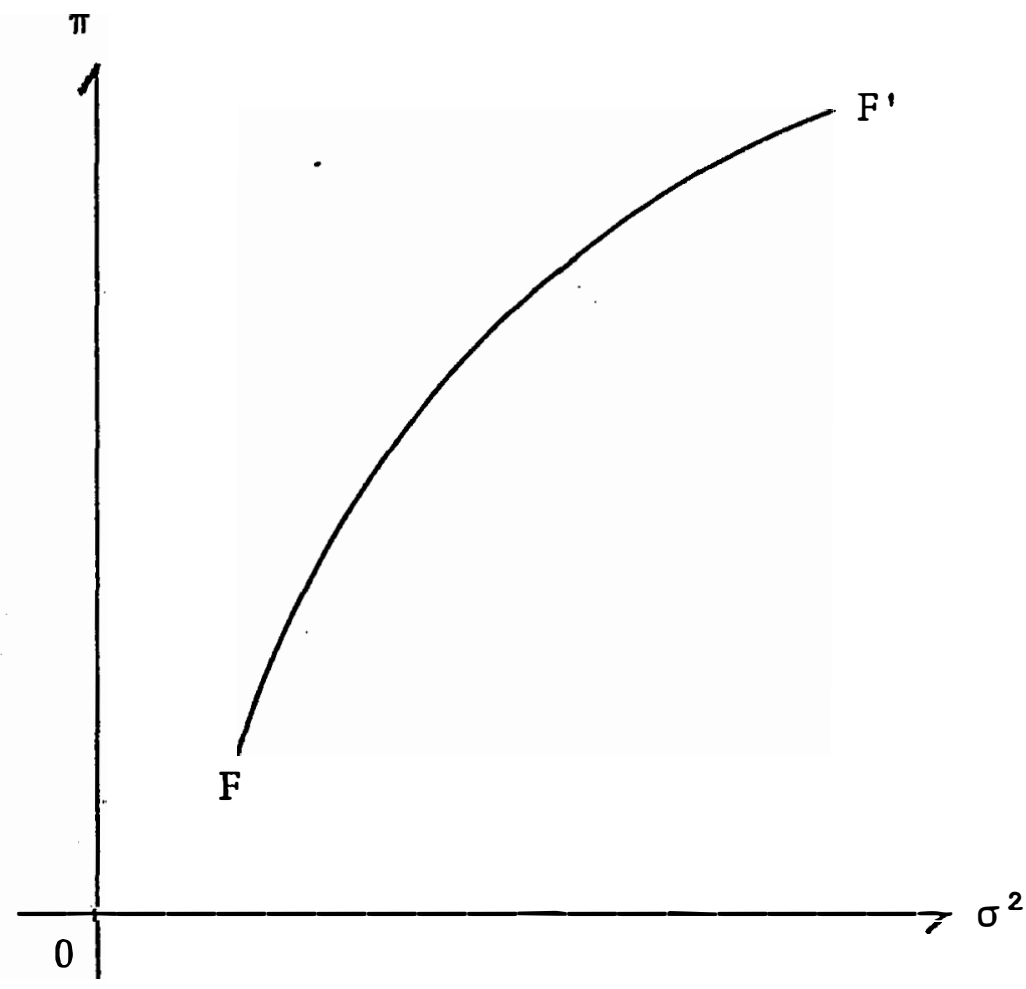

Fig. 2. Representação Hipotética da Fronteira Eficiente

delo, transforma o problema de modo que passa a ser necessá-. rio o uso da programação quadrātica (FREUND, 1956) :

$$
\begin{array}{ccc}
\text { Minimizar } \sigma^{2}=\sum_{j=1}^{n} \sum_{k=1}^{n} x_{j} x_{k} \sigma_{k j} \\
\text { Sujeito a } \quad \pi \quad=\sum_{j=1}^{n} c_{j} x_{j} \text { e }(0 \leqq \pi \leqq \bar{\pi}) \\
\text { e } & \sum_{j=1}^{n} a_{i j} x_{j} \leqq b_{i} & (i=1,2, \ldots, m) \\
\text { e } & x_{j} \geqq 0 & (j=1,2, \ldots, n)
\end{array}
$$


Neste modelo, $\sigma_{k j}$ é a covariância entre os retornos das cultú ras $k$ e j. 0 valor de $\pi$ deve, neste caso, ser parametrizado, assumindo sucessivamente valores crescentes a partir de zero, até que a fronteira eficiente tenha sido gerada.

A programação quadrātica desenvolvida por MARKOWITZ (1952) para a Anālise de Portfolio é um método muito útil no planejamento agrícola pois considera o risco asso ciado à obtenção de lucro. Mas, sua aplicação depende de um programa especial de computador, de acesso ainda não generalizado. Porisso, a programação quadrática é pouco usada no Brasil. Portanto, neste trabalho foi usado uma técnica de programação linear, como aproximação à programação quadrātica.

Uma aproximação linear ao modelo definido pelas equações e restrições 4 a 7 acima é o sugerido por Hazell. Pode-se usar o "desvio absoluto com relação à média" como medida de dispersão ou risco. 0 problema pode; en tão, ser resolvido por programação linear e a fronteira eficiente da fig. 2 é aproximada por pequenos segmentos de reta (HAZELL, 1971).

Para gerar as diversas opções tecnológicas (pa cotes) que compõe a matriz A e o vetor $x$, podem ser estimadas "funções" de produtividade para as culturas, especialmente pa. ra o milho. A fig. 3 mostra exemplos dessas funções (PERES, 1976). As atividades OA, OB, OC e OD correspondem a "paco- 
tes" diferentes de tecnologia e são consideradas atividades diversas. Por umá combinação linear das atividades OA e $O B$, qualquer ponto na reta $\overline{A B}$, por exemplo, pode ser atingido. Assim, pode-se, simultâneamente, eliminar ou reduzir uma séria limitação da programação linear (1inearidade das funções de produção) e identificar porque determinada produti vidade está sendo preferida.

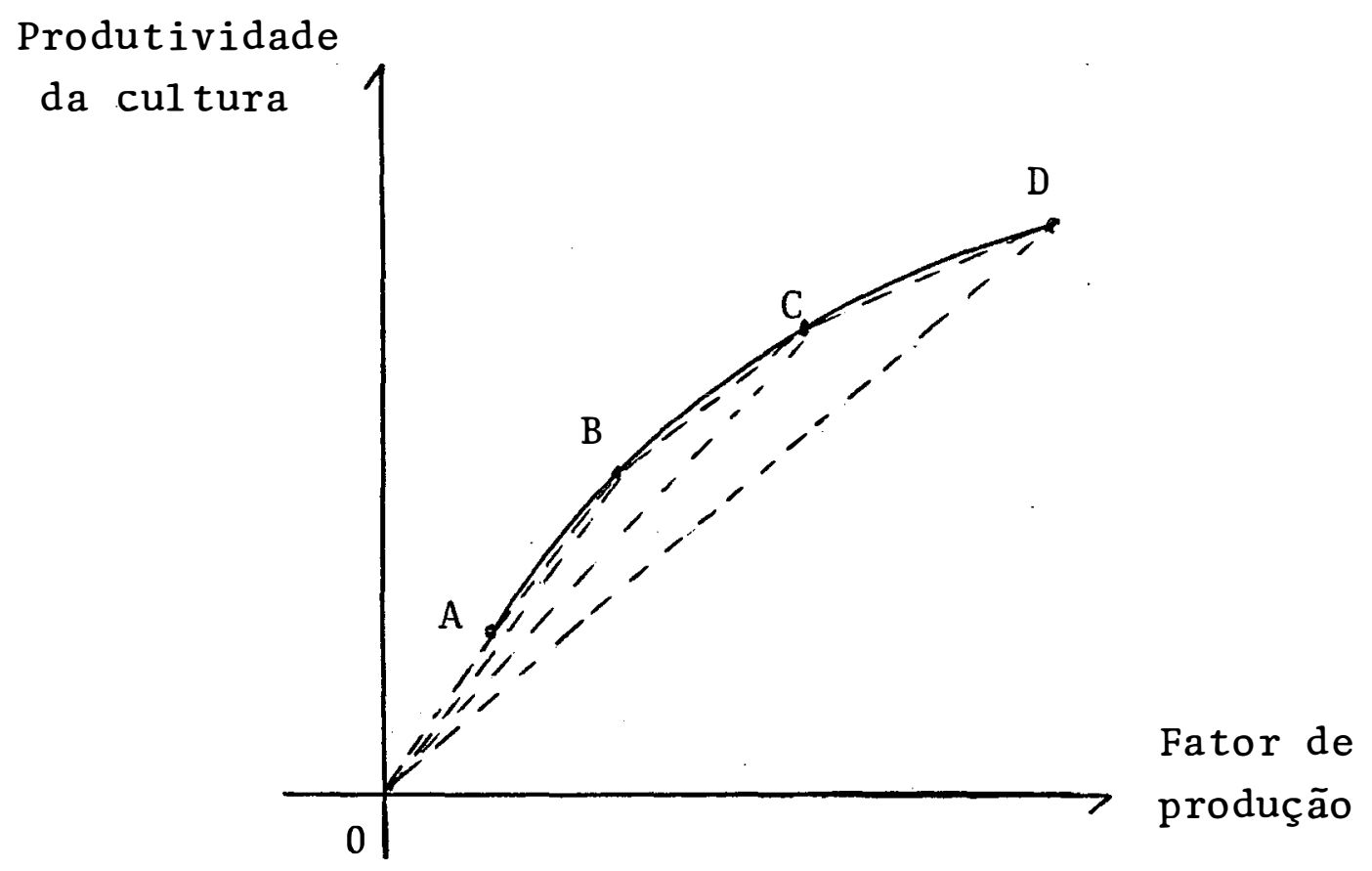

Fig. 3. "Pacotes Tecnológicos" de Produção

Os modelos de programação linear permitem a subdivisão do período de produção em sub-períodos. Isto per mite testar a hipótese de existência de baixas produtividades devido a estacionalidade no uso dos fatores. Sugestões 
sobre liberações oportunas de crédito, por exemplo, podem nascer da verificação de que existem problemas deste tipo for çando os agricultores a adotarem determinadas tecnologias que resultam em mais baixas produtividades.

0 modelo modificado por HAZELL (1971) è dado por:

$$
\begin{aligned}
& \operatorname{Minimizar} \frac{|z|}{2}=\underset{v=1}{\bar{v}} q_{v} \\
& \text { Sujeito a } \sum_{j=1}^{n} x_{j} Q_{v j}+q_{v} \geq 0 \quad \forall \quad v \\
& \sum_{j=1}^{n} c_{j}^{\prime} x_{j}=\pi \\
& \sum_{j=1}^{n} c_{i j} x_{j} \leq b_{i} \quad \forall \quad i \\
& x_{j} \geq 0 \quad \text { e } \quad q_{v} \geq 0
\end{aligned}
$$

onde,

$|Z|$ é a soma dos desvios absolutos com relação às médias das receitas brutas expressas a preços "reais" esperados de julho de 1979 ;

$Q_{v j}$ é o desvio em relação à receita média dos cinco anos $(1974 / 1975$ a $1977 / 1979)$ da cultura $j$ no ano $v \cdot(\bar{v}=5)$. 
Devido às restríções 9 e 12 , quando $\sum x_{j} Q_{v j} \geq 0$ o $q_{v}$ corréspondente assume o valor zero.

$Q_{v j}=0$ quando a atividade correspondente não é atividade de produção ou de compra de milho.

$\mathrm{q}_{\mathrm{v}}$ é uma variāvel auxiliar que mede a soma dos desvios negativos .

o desvio em relação à receita média é dado por:

$Q_{v j}=\left(P_{v j} d_{v j}-\bar{R}_{j}\right) \quad v=1, \ldots, \bar{v} \quad$ e $\left.\quad j=1, \ldots, n\right)$

onde,

$P_{v j}$ é a produtividade corrigida (conforme explicado no capítulo 5) da cultura $j$ no ano $v$. Os dados de produtividade foram obtidos através do Prognóstico do Instituto de Econo mia Agrícola para a Divisão Regional Agrícola (DIRA) de Ribe i rão Prẹto. Para bovinos de corte e suínos comuns (tipo banha) foi admitida produtividade física constante.

$\mathrm{d}_{v j}$ é o preço médio recebido pelos agricultores da DIRA de Ribeirão Preto, esperados em julho de 1979 (final da safra em estudo) para a cultura $j$ no ano $v$.

$\overline{\mathrm{R}}_{j}$ é a receita média esperada para a cultura $j$. As re ceitas médias $\overline{\mathrm{R}}_{\mathrm{j}}$ foram calculadas de acordo com: 


$$
\sum_{v=1}^{\bar{N}} \mathrm{P}_{v j} \mathrm{~d}_{v j} / \overline{\mathrm{v}}=\overline{\mathrm{R}}_{\mathrm{j}} \quad \mathrm{j}=1, \ldots, \mathrm{n}
$$

o valor $\bar{y}$ é o número de anos considerados (no caso cinco anos).

Parametrizando o valor $\pi$ (1ucro) desde o valor $\bar{\pi}$ dado peía solução de Programação Linear, até valores próxí mos de zero, pode-se gerar a chamada "fronteira eficiente". Como os recursos da propriedade agrícola são limitados, esta "fronteira eficiente" é definida como o lugar geométrico dos pontos correspondentes ao mínimo de risco necessário para atingir determinado valor da função lucro $(\pi)$.

O risco foi medido, portanto, pela soma dos desvios absolutos com relação às médias dos retornos das culturas nos últimos cinco anos. Com, a introdução de risco no problema de Programação Linear, de acordo com o modelo 8 a 12 foi montada uma matriz com 61 atividades e 49 restrições.

0 próximo passo será discutir algumas limitações do enfoque da Média-Variância.

2.1.1. Limitações do modelo

Embora o enfoque da média-variância para estudo de risco seja muito comum na literatura (PERES, 1976 e MATTOS, 1979), ele tem sido criticado por suas implicaçōes im 
plícitas ou explícitas.

Quando só se consideram os dois primeiros momentos de uma distribuição (média e variância) muitas informa ções são perdidas. Não se considerar o terceiro momento (as simetria) equivale à prèssuposição de que as probabilidades de ocorrência de eventos (receitas brutas no presente caso) maiores que a média (desejāvel) são iguais às de ocorrência de eventos menores que a média (indesejável).

A escolha da variância ou do desvio absoluto com relação à média como "proxy" para risco è arbitrāria. Qualquer medida de dispersão em torno de uma média de valor central poderia ser utilizada.

0 presente modelo só considera o risco do lado da receita. Riscos de variações nos preços de insumos ou da não disponibilidade destas nos momentos oportunos não são considerados.

As fronteiras eficientes podem ser (e são) cal culadas sem a utilização de qualquer informação sobre o grau de aversão ao risco dos agricultores. A determinação de pon tos de equilíbrio depende de pressuposição sobre a forma explícita das curvas de utilidade (indiferença) dos agricultores o que é um objetivo muito difícil, se não impossível, de ser conseguido. 
2.2. 0 modelo de expectativa de preços

Foi construído um modelo de expectativa ' é determinado uma taxa de crescimento esperado dos preços

0 modelo baseia-se na pressuposição de que o preço esperado é função dos recentes (n ủltimos anos) níveis de inflação verificados no país. Normalmente os produtores agrícolas baseiam sua expectativa de inflação futura na experiência passada. Logo, foram ajustados modelos de expectatí va de crescimento dos preços, sendo os preços recebidos pelos agricultores paulistas (I.E.A.), a variāvel dependente, 1inearmente, dos indices de inflação nos dois anos anteriores (medidos pelo indice " 2 " da Conjuntura Econômica). Foram usadas variáveis "dummy" para captar variações nas políticas com relação ao setor e de controles monetários acontecidos a partir de 1964 e, novamente, em 1973-74. A expectativa com relação à inflação foi modificada devido à mudança política em 1964 e devido à crise internacional do petróleo em 1973 - 1974.

$$
\text { No modelo formal }
$$

$$
\begin{aligned}
\phi_{t}= & \alpha_{0}+\alpha_{1} i_{t-1}+\alpha_{2} i_{t-2}+\alpha_{3} D+\alpha_{4} D i_{t-1}+ \\
& \alpha_{5} D i_{t-2}+\alpha_{6} D_{1}+\alpha_{7} D_{1} i_{t-1}+\alpha_{8} D_{1} i_{t-2}{ }^{2}
\end{aligned}
$$

2 Esta formulação é semelhante à utilizada em PINAzzA et alii (1979). 
onde,

$$
\begin{aligned}
& \phi_{t} \text { é a variação percentual no índice de preços recebi- } \\
& i_{t-k} \text { é a variação percentual no "indice } 2 " \text { da Conjuntura } \\
& \text { Econômica no período } t-k(k=1 \text { e } 2) \text {; } \\
& \text { D é a variāvel "dummy" ; } D=0 \text { para } t \leq 1964 \\
& \mathrm{D}=1 \text { para } \quad \mathrm{t}>1964 \\
& \mathrm{D}_{1} \text { é a variável "dummy"; } \mathrm{D}_{1}=0 \text { para } \mathrm{t} \leq 1973 \\
& \mathrm{D}_{1}=1 \quad \text { para } \quad t>1974
\end{aligned}
$$

Foi usado o método de quadrados mínimos ordinários com um programa "step-wise" para o ajustamento do mode 10. Com a regressão ajustada, projetou-se a variação espe rada no indice de preços recebidos pelos agricultores para 1979. Com este indice foram inflacionados os preços recebidos (por produto) em 1978, obtendo-se assim os preços esperados para os diversos produtos no ano agrícola $1978 / 79$.

Este modelo sugere antecipadamente algumas interpretações quanto aos coeficientes. Uma intercessão( $\left.\alpha_{\sigma}\right)$ positiva (negativa) indica que os preços recebidos pelos agricultores aumentam (diminuem), respectivamente, mais que a inflação. Este coeficiente $\left(\alpha_{0}\right)$ captura mudanças sistemáticas no nível de preços que não são captadas pelo processo autorregressivo. Espera-se o intercepto $\left(\alpha_{0}\right)$ igual a 
zero, o que significa que os preços recebidos pelos agriculto res acompanham a inflação.

Por causa da pressuposição de que os mais recentes níveis de inflação são mais importantes na formação de expectativas de preços pelos produtores espera-se que os coeficientes $\alpha_{1}$ e $\alpha_{2}$ sejam positivos e $\alpha_{1}>\alpha_{2}$.

Convém mencionar também que a inflação é cons $\underline{i}$ derada neste modelo somente no lado do produto pois, do lado do fator é assumido que os produtores sabem antecipadamente que preços serão pagos por eles. Com respeito aos insumos modernos esta pressuposição é realista, mas não é com respeito ao fator trabalho e às máquinas alugadas (PERES, 1976). 
3. A REGIÃO, DADOS E PROCEDIMENTOS

Neste capítulo são apresentadas informações bá sicas sobre a região em estudo, os dados utilizados na pesqui sa e o procedimento adotado para selecionar propriedades representativas da região.

\subsection{A região.}

Como foi dito anteriormente, o estudo faz parte do projeto interdisciplinar de pesquisa - Projeto Milho II - que vem sendo desenvolvido por departamentos da ESALQ - USP. Este projeto, com base em conhecimentos prévios sobre as áreas do Estado, selecionou a região de Ribeirão Preto, que é uma das nove divisões agrícolas (DIRA) do Estado de São Paulo, para o estudo em questão. Esta região foi escolhida não só porque é a mais importante em produção do estado, como oferece tipos de cultura diversificados. Ocupa o primeiro lugar do estado na produção de algodão, soja, laranja, cana-de-açū- 
car e tomate é uma das mais importantes regiōes produtivas do País em feijão, café, milho, amendoim e arroz (I.E.A.-S.A., SÃO PAULO, diversos números).

Convém ainda mencionar que a região escolhida é uma área muito dinâmica na comercialização de seus produtos, sendo bem servida por bancos que fazem empréstimos agrícolas, por firmas que vendem insumos para a agricultura e por transportes ferroviário e rodoviārio. É também uma das regiões mais populosas do estado.

Pela tabela 2, pode-se verificar que a região apresenta mudanças rápidas com respeito à entrada de novas cul turas. Os dados sugerem que, durante este período, a ārea de arroz quase dobrou de 1966 para 1969, declinou em 1972 e cresceu novamente em 1975. A área de soja aumentou vinte e oito vezes. A do algodão e do milho cresceram até 1972 a uma taxa mais baixa e declinaram em 1975. 0 algodão sofreu uma redução mais drástica. Parece que a grande diminuição na área de milho e algodão de 1972 a 1975 foi devido ao surgí mento da cultura da soja e a mudanças na política econômica (MATTOS, 1979) .

A região(DIRA) está subdividida em oitenta municípios, que abrangem uma ārea de $37.000 \mathrm{~km}^{2}$ de terra roxa legítima em cinquenta por cento desta área e cerca de vinte tipos de solos no restante (MATTOS, 1979). 
Tabela 2. Área de Quatro Culturas Anuais na Região de Ribeirão Preto, São Paulo, 1966 - 1975

\begin{tabular}{lrrrr}
\hline \multirow{4}{*}{ Cultura } & \multicolumn{5}{c}{$\bar{A}$ R $E$ A $($ ha $)$} \\
\cline { 2 - 5 } & 1966 & 1969 & 1972 & 1975 \\
\hline Arroz & 96.292 & 181.331 & 114.500 & 134.700 \\
Milho & 169.352 & 271.863 & 342.000 & 244.800 \\
Soja & 8.857 & 42.471 & 100.000 & 245.900 \\
Algodão & 51.062 & 76.690 & 113.000 & 68.300 \\
\hline
\end{tabular}

Fonte: Instituto de Economia Agrícola, Informações Econômicas, São Paulo (citado em MATTOS, 1979) .

Para representar esta extensa região foram selecionados cinco municípios da micro-região Serra de Jaboticabal (MOLINA $F^{\circ}$ e BURKE, 1981), que podem ser identificadas no mapa adiante (fig. 4). Jaboticabal, Pirangi, Viradou ro, Pitangueiras e Taquaritinga foram escolhidos entre os dezesseis municípios dessa micro-região por causa de caracterís ticas especiais que melhor assemelharam aos objetivos do Projeto Milho II : Diversificação da produção; Variabilidade dos solos e Conhecimento da área pelos entrevistadores.

Para esta seleção foi solicitada a ajuda de Técnicos da Divisão Regional Agrícola de Ribeirão Preto e de 


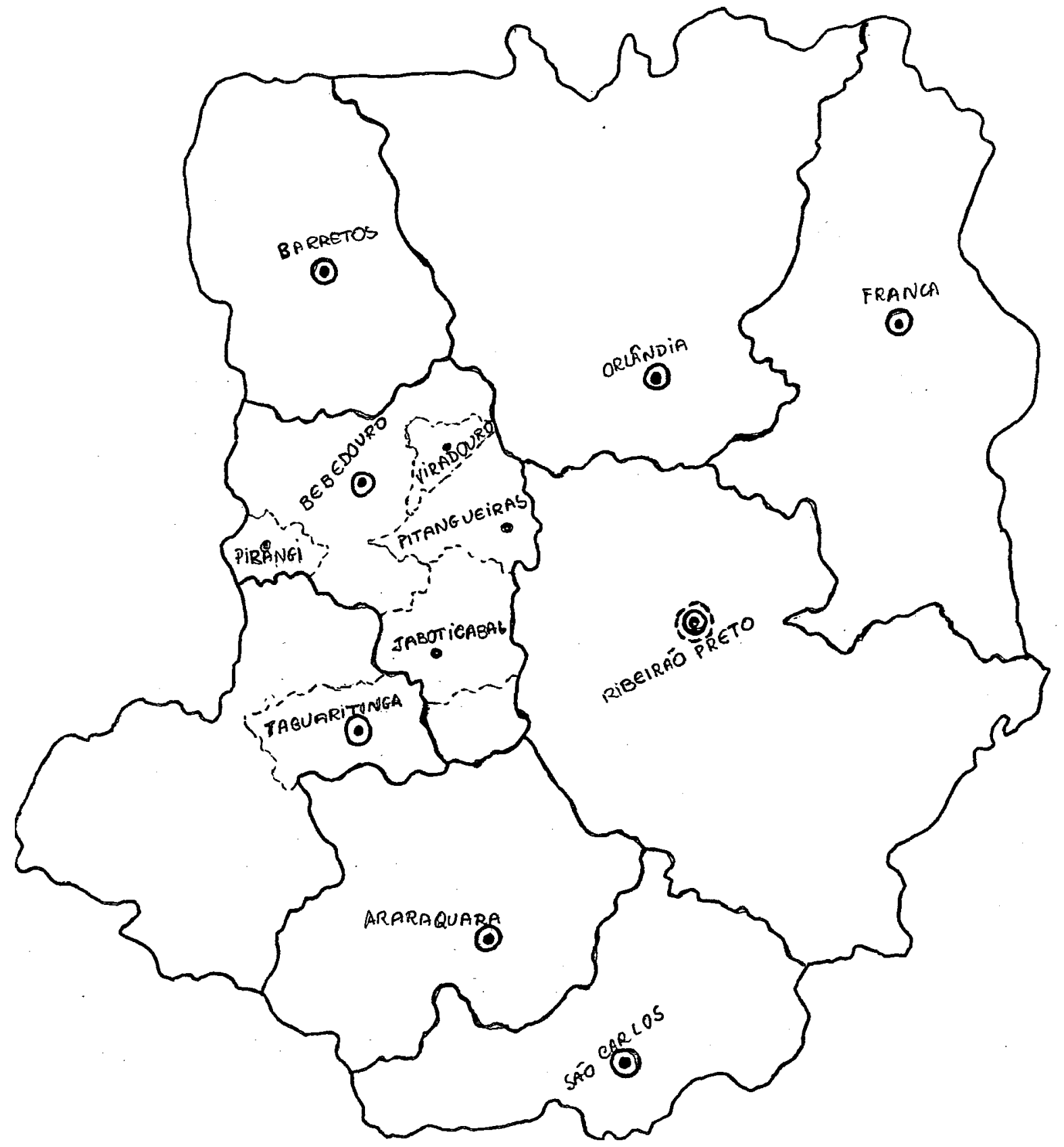

Fig. 4. A Divisão Regional Agrícola (DIRA) de Ribeirão Preto e a Área da Amostra 
duas Delegacias pertencentes a esta divisão: Taquaritinga e Bebedouro e, dos Técnicios de Casas de Agricultura da micro-re gião. Com o auxilio desses Técnicos, pôde-se destacar os municípios que apresentavam maior volume de produção demilho. Foi verificado também que, esta cultura na região não è tão difundida como se esperava. No entanto, os produtores de mi 1ho estavam espalhados mais ou menos uniformemente por toda a ärea.

Esta região está situada ao norte do Planalto Ocidental, banhada pelos rios Turvo, Pardo e seus afluentes, com clima quente e invernos secos. A vegetação rala de campos e cerrados situa-se à oeste e sul da micro-região. Quan to ao solo, predomina o arenito Bauru, mas há afloramentos de rochas basālticas que deram origem aos solos mais ricos, como é o caso dos Municípios de Pitangueiras, Jaboticabal, Viradou ro e Terra Roxa, a leste dessa micro-região (MOLINA Fo el BURKE, 1981).

\subsection{Os dados}

Os dados utilizados para esta pesquisa foram coletados através de 3 tipos de questionários complementares aplicados a uma amostra de 251 produtores de milho de cinco municípios da micro-região homogênea Serra de Jaboticabal. Foram planejadas entrevistas com os mesmos agricultores da amostra: a primeira em julho de 1978, a segunda em janeiro 
de 1979 e a terceira em julho de 1979. Devido a recusas, morte, mudanças de residência, etc, dos agricultores entrevis tados na primeira visita houve una redução no número dos mesmos entre os três levantamentos.

Os questionārios contêm informaçōes sobre as diferentes fases do ciclo de produção. Estes dados foram usados na construção das matrizes de programação do modelo. A pre sente pesquisa utilizou o primeiro questionário para a caracteri zação das unidades de produção agrícola. Do segundo foram extraídos dados sobre os sistemas de produção e sobre a percepção dos agricultores quanto ao nível de tecnologia recomendado das culturas, assim como sobre o nível de tecnologia efetivamente alcançado. 0 terceiro questionário, forneceu dados sobre as produtividades das culturas.

A tabela 3 apresenta os cinco municípios abran gidos pelos levantamentos e o número de questionários coletados em cada levantamento.

A matriz foi construída com dados destes levan tamentos e com dados de custo de produção publicados pela - Secretaria da Agricultura do Estado de São Paulo e ainda foram usadas informações resultantes de experimentos conduzidos pelos serviços de pesquisa agronômica do estado. Estes últimos dados foram usados no cálculo do risco de produtividade associado a cada cultura juntamente com dados de preços recebidos pelos agricultores, coletados pelo Instituto de Economia Agrícola. 
Tabela 3. Número de Unidades de Produção Agrícola que Compõem a Amostra em Cada Levantamento nos Cinco Municípios da Micro-Região Homogênea Serra de Jaboticabal.

\begin{tabular}{lccc}
\hline Município & Julho de 1978 & Janeiro de 1979 & Julho de 1979 \\
\hline Jaboticabal & 62 & 58 & 58 \\
Pirangi & 61 & 56 & 52 \\
Viradouro & 45 & 43 & 40 \\
Pitangueiras & 62 & 56 & 52 \\
Taquaritinga & 21 & 21 & 18 \\
& & & 234 \\
\hline \multicolumn{1}{c}{ TOTAL } & 251 & 234 & 20 \\
\hline
\end{tabular}

Fonte: MOLINA Fo e BURKE, 1981.

Procurou-se tambēm entrevistar todos os produtores de sementes de milho da área visando determinar eventuais diferenças tecnológicas utilizadas por estes produtores e os demais produtores de milho.

Alguns desses dados foram revistos e outros completados com a visita feita novamente à região em março de 1981. Os valores das matrizes (coeficientes tecnológicos e restrições foram submetidos à apreciação de agrônomos das Casas da Agricultura da Região e a alguns agricultores mais esclarecidos para verifücação de sua consistência. Tratando-se 
do modelo "normativo" de comportamento, este procedimento po de ser indicado.

3.3. 0 procedimento adotado

Como foi dito anteriormente vārias alternat $\underline{i}$ vas foram discutidas para a escolha da área da amostra e das propriedades agrícolas. 0 universo da pesquisa constou de todos os produtores de milho dos cinco municípios seleciona dos. Estes agricultores foram identificados pelos dados das firmas vendedoras de sementes de milho e das Casas da Agricul tura. Os compradores de sementes (produtores) do ano agríco la 1977 / 78 foram então localizados no mapa desses municípios escolhidos e em seguida foi feita a distribuição dos mesmos por área. Dos dados de previsão de safras do Instituto de Economia Agrícola pôde-se tirar informações do número de produtores e de estimativas do volume de produção de cada municí pio. Por essas informações pode-se verificar que não havia concentração dos produtores de milho em determinadas áreas pois eles estavam dispersos pelas mesmas.

O primeiro passo no trabalho de campo foi identificar os produtores de milho da ārea. 0 mapa assinala va os compradores de sementes de milho mas, foi necessārio percorrer cada sub-região até alcançar $10 \%$ do total dos agri cultores em geral. 
Nem todos os agricultores eram produtores de milho, o que levou a fração de amostragem a mais de $10 \%$. Na verdade, foi constatado mais tarde pelos dados de previsão de safra do Instituto de Economia Agrícola que cerca de $50 \%$ da safra de milho da região foi produzida pelos agricultores entrevistados nesta pesquisa, o que leva a crer que cerca de $50 \%$ dos produtores de milho da micro-região estão representados pela amostra.

O sejgundo passo constou da mudança no número de questionários para cada município. Foi aumentado o número de questionários para Viradouro e Pitangueiras e foi diminuỉdo em Taquaritinga. Pelos trabàlhos de campo pode-se verificar que as informações para o projeto do milho eram mais ricas e mais interessantes nos dois primeiros municípios do que no terceiro, onde alguns agricultores se recusaram a dar informações ao entrevistador e onde o milho é uma atividade de muito pouca expressão econômica. Em Taquaritinga também a ārea é muito grande e os produtores estão bastante dispersos. O número de casos ainda foi aumentado para Pirangi porque este município apresentou, como o outro, grande número de casos com culturas de subsistência.

Finalmente, os produtores de sementes de milho foram também entrevistados. Objetivava-se neste terceiro pas so conseguir alguma diferença no sistema de produção destes produtores com os de produção de grãos. 
Inicialmente, foi feita uma primeira tentativa de elaborar a matriz dos coeficientes técnicos para as "propriedadés típicas" dos grandes e pequenos produtores da região. De acordo com o trabalho desenvolvido por MOLINA FILHO (1976), foi feita uma classificação preliminar das 251 un $\underline{i}$ dades produtivas (U.P.) em três categorias: Empresas Capitalistas, Empresas Familiares e Empresas Camponesas Pré-empresariais. (Não foram encontrados "latifúndios", segundo aquela classificação, nesta tipificação preliminar). As "empre sas capitalistas" eram, em geral, as maiores propriedades. 0 trabalho inicial foi desenvolvido sob a pressuposição implíc $\underline{i}$ ta de que estas empresas (as maiores) seriam aquelas que apre sentavam maiores produtividades das culturas.

Depois que parte da matriz dos coeficientes téc nicos da propriedade típica das grandes empresas tinha sido estimada, verificou-se que as expectativas de produtividade do milho para aqueles agricultores incluiam valores altos e baixos, quando comparados com o valor médio. Decidiu-se, então, testar a existência de correlação entre produtividade esperada do milho e diversas variáveis.

Primeiramente, todos os 251 produtores de mi1ho que compõem a amostra, foram classificados em 18 categorias: proprietário exclusivo, proprietário associado, arrendatário, parceiro, colono, ocupante ou posseiro, morador, agre gado, empreiteiro, proprietário exclusivo e arrendatário, pro 
prietário exclusivo e parceiro, proprietário exclusivo arrendatário e parceiro, proprietário associado e arrendatário, parceiro e morador, proprietário associado e parceiro, proprietário associado-arrendatário e parceiro, proprietário exclusivo e associado, proprietário exclusivo-associado e parceiro. Feita esta divisão em categorias do chefe da unidade produtiva procurou-se verificar se existia correlação entre produtividade esperada e tamanho da propriedade e produtivida de observada e tamanho da propriedade. Para isto foram tira dos dados do $1^{\circ}$ e do 3 levantamentos como: área total da empresa, área plantada de milho em 1977 / 78, produção colhida em $1977 / 78$, ärea planejada e produtividade esperada, ärea plantada de milho em $1978 / 79$ e produção neste mesmo ano. As correlações encontradas foram baixas indicando a não existência de relação entre área da unidade produtiva e produtivi dade da cultura do milho. Em seguida testou-se, através do test $t$ de Student, a existência de diferença significativa entre as produtividades médias esperadas para os grupos de pro prietārios e não proprietários. Aquele teste revelou ausência de significância (mesmo a baixos níveis de probabilidade) entre as produtividades esperadas. Partindo-se dos testes mencionados e como cada categoria pode representar as demais, a opção foi por trabalhar somente com proprietários exclusivos. Dos três levantamentos foram tirados dados para compor as matrizes típicas como: porcentagem da terra arável, quali dade da terra, tipo de solo, adubação, área planejada e destị 
no do milho, quais as culturas da propriedade ou o que espera plantar, o que foi vendido, se a semente foi comprada, qual o tipo de semente, espaçamento, atividade econômica do chefe da U.P., se toma empréstimo, onde e valor do empréstimo, se resi de na unidade produtiva, quantas visitas à unidade produtiva, se o milho é consorciado e quais as culturas que antecederam o milho e demais coeficientes técnicos.

Foi feita uma separação dos proprietários exclusivos em dois grupos de acordo com a produtividade média esperada do milho: os de alta produtividade (maiores do que a produtividade média) e os de baixa produtividade (menores do que a média esperada). Em seguida, foi feita a opção de trabalhar com uma amostra menor de questionários (30). Foram, portanto, selecionados os quinze agricultores extremos de cada grupo.

Foi montada a matriz dos coeficientes que caracterizam a propriedade típica dos produtores de alta produtividade. Em seguida foi montada a matriz dos coeficientes que caracterizam a propriedade típica dos produtores de produ tividade abaixo da média. $\quad 0$ ano agrícola foi dividido em cinco períodos. As atividades foram distribuídas nos diver sos períodos e os valores representativos da atividade típica foram aqueles da moda. Este procedimento foi adotado para as culturas de arroz, algodão, soja, milho, amendoim, café, laranja e pastagem. Além das culturas mencionadas, foram 
consideradas duas atividades de exploração animal: bovinocul tura de corte e suinocultura.

Os coeficientes técnicos encontrados para cada nível de produtividade foram quase os mesmos. Por causa da dificuldade em separar estes coeficientes foi feita a segunda opção de trabalhar só com uma matriz grande, na qual foram incluídos os dois extremos de produtividade através de diferentes atividades (tecnologias) para cada cultura. 
4. ATIVIDADES E RESTRIÇÕES USADAS NO MODELO DE PROGRAMAÇÃO

A presente pesquisa pressupõe um modelo de de cisão para propriedades típicas dos produtores de milho da re gião Serra de Jaboticabal.

0 modelo usou os preços dos produtos de acordo com um crescimento "esperado" para $1978 \% 79$ nos preços receb dos pelos produtores. Para se obter este crescimento esperado foi utilizado o modelo de expectativa de preços, descrito no segundo capítulo.

Portanto, este capítulo inclui não só a descrị ção das atividades e restrições usadas no modelo de programação linear, admitindo, inicialmente, maximização de lucros, como o resultado da simula ação da formação de expectativas dos preços futuros. A descrição dos resultados do modelo de crescimento dos preços recebidos pelos agricultores paulistas está incluído na primeira parte. Em seguida, foram descritas as principais atividades consideradas na matriz dos coefi 
cientes que caracterizam a propriedade típica dos produtores de milho na região estudada. Para cada atividade produtiva foi feita a estimativa de custo (usaram-se os preços efetivamente pagos pelos agricultores) o correspondente retorno anual esperado e os recursos requeridos para sua produção. A terceira parte contém as restrições (R.H.S.) dos fatores de produção característicos daquelas propriedades. A introdução de risco será discutida no próximo capítulo.

\subsection{Expectativa de preços}

0 modelo de expectativa de preços proposto no segundo capítulo foi estimado através deprograma "step-wise". A equação que apresentou melhor ajustamento ${ }^{1}$ aos dados foi:

$$
\begin{gathered}
\phi_{t}=0,141+1,322 i_{t-1}-0,863 i_{t-2}+0,238 D- \\
(2,9966) * *(1,4861)^{*}(1,2529) \\
-2,534 D i_{t-1}+1,526 D i_{t-2}+0,287 D_{1} \\
(1,5801) *(1,4622)^{*}(1,3042)
\end{gathered}
$$

1 As séries de dados utilizados nesta regressão (1948 a 1978) foram tiradas de FUNDAÇÃO GETULIO VARGAS e SECRETARIA DA AGRICULTURA (1972).

Os números entre parênteses são os valores de $t$.

* Valores estatisticamente diferentes de zero ao nivel de confiança de $20 \%$.

* * Idem a $1 \%$. 
onde:

$$
\begin{array}{lll}
\mathrm{D}=0 & \text { para } & \mathrm{t} \leq 1964 \\
\mathrm{D}=1 & \text { para } & \mathrm{t}>1964 \\
\mathrm{D}_{1}=0 & \text { para } & \mathrm{t} \leq 1973 \\
\mathrm{D}_{1}=1 & \text { para } & \mathrm{t}>1973
\end{array}
$$

$\mathrm{R}^{2}=0,44$

0 teste de Durbin-Watson para o modelo completo (como descrito no capítulo 2) = 2,07 . A hipótese de ausência de autocorrelação nos resíduos não ê rejeitada.

Da equação' 16 foram eliminados os termos

$D_{1} i_{t-1}$ e $D_{1} i_{t-2}$, o que faz esta equação diferir da equação 15 proposta inicialmente. Os coeficientes destas duas variāveis não foram significativamente diferentes de zero ao nível de 20\% e tem desvios-padrão maiores que os valores dos coeficientes. Assim, a inclusão de $\mathrm{D}_{1}$ alterando as declividades ou coeficientes das variāveis $i_{t-1} e i_{t-2}$ não adiciona muitas informações ao modelo. A inclusão destas variáveis traz, ainda, efeitos espūrios à regressão, aumentando os desvios-padrão dos outros coeficientes estimados. Possivelmente o pequeno número de valores diferentes de zero desta variā 
vel (poucas observações) é responsável pelas altas variâncias dos coeficientes estimados.

0 coeficiente $\alpha_{1}$ foi significante ao nível de $1 \%$ Os coeficientes $\alpha_{2}, \alpha_{4}$ e $\alpha_{5}$ foram significativamente diferentes de zero ao nível de $20 \%$ de probabilidade. Já, os coeficientes $\alpha_{3}$ e $\alpha_{6}$ das variáveis "dummy" ( $D$ e $D_{1}$ ), embora não significantes, tiveram seus desvios-padrão menores que os valores dos respectivos coeficientes.

Substituindo os valores observados em 1978 e $1977\left(i_{t-1}=0,387\right.$ e $\left.i_{t-2}=0,427\right)$ na equação 16, verificouse que a variação no índice de preços esperados para 1979 foi estimada em $48 \%$.

o modelo pressupõe que os agricultores baseiam sua expectativa de preços futuros na experiência passada. Por tanto, o indice de preços recebidos pelos agricultores será incrementado pela taxa projetada para 1979. Este novo índice serā utilizado para inflacionar os preços médios recebidos, produto a produto, pelos produtores da DIRA de Ribeirão Preto, tornando-os valores reais esperados.

\subsection{Atividades, recursos requeridos e função objetivo}

Esta seção do capítulo quatro define as atividades de produção e os recursos ou restrições da propriedade típica. 
Os coeficientes que compoõem a matriz foram construídos com dados observados da amostra e com dados de diversas publicações do Instituto de Economia Agrícola da Secretaria da Agri cultura de São Paulo.

Como foi dito anteriormente, a matriz foi construí da admitindo-se a existência de diversos níveis de produtividade (opções tecnológicas) para cada atividade: As diferenças tecnológicas foram notadas no uso de máquinas, de trabalho e de época de plantio e colheita.

0 ano agrícola foi subdividido em cinco períodos: julho/setembro (I), outubro (II), novembro/janeiro (III), fevereiro/março (IV) e abril/junho (V). O primeiro período correspondeu em geral, à preparação do solo: limpeza, aração, gradeação e calagem. Durante o período II foram feitas as operações de riscação, adubação e plantio. Para algumas culturas, inclusive para o milho, a operação de plantio foi tambēm permitida em novembro. Nos períodos III e IV realizam-se adubações em cobertura, pulverizações, capinas mecânica ou animal, capina manual, transporte interno, desbastes ou raleações. A separação dos períodos destas operações depende de cada cultura. O último período correspondeu à colheita para a maioria das culturas mas para outras culturas a colheita foi feita no quarto período ou em julho, como foi o ca so do café. A colheita da laranja foi considerada em três períodos diferentes porque alguns produtores desta cultura fazem esta operação três vezes ao ano. Transporte interno foi 
considerado num só período, embora ele seja feito em todos eles. Como não foi possível separā-lo preferiu-se colocá-1o no período de maior concentração. As tabelas que descrevem, detalhadamente, os coeficientes utilizados encontram-se no Apêndice A.

A função objetivo $\pi$ (1) corresponde ao produto do vetor $c^{\prime}$ (1inha) das margens brutas das diversas cul.turas pelo vetor $x$ (coluna) das atividades. O vetor c corresponde às receitas de cada atividade (elementos com sinais positivos) e à compra de insumos, contratação de mão-de-obra, créditos para as culturas e compra de milho incluídas como despesas (elementos com sinais negativos).

Os elementos do vetor $x$ que correspondem às atividades, foram definidos como:

$\mathrm{X}_{01}=$ Arroz I plantado em novembro, com colheita por empreita da (colhedeira), plantado com força animal, em terra de 1a. e produtividade esperada de $56 \mathrm{sc} .^{2}$ de $60 \mathrm{~kg} /$ alqueire;

$\mathrm{X}_{02}=$ Arroz II plantado em outubro, com colheita manual, com plantio, adubação e capina mecânica feito com força an mal, em terra de $2 a$., com adubação em cobertura e produ tividade esperada de $56 \mathrm{sc}$. de $60 \mathrm{~kg} / \mathrm{alqueire;}$

2 sc. = sacas 
$\mathrm{X}_{03}=$ Arroz III plantado em novembro, com colheita por empre $\underline{\mathbf{i}}$ tada (colhedeira), com tração motomecanizada, em terra de 1 a., com adubação em cobertura e produtividade esperada de $66 \mathrm{sc}$. de $60 \mathrm{~kg} / \mathrm{alqueire;}$

$\mathrm{x}_{04}=$ Soja I plantado em novémbro, colheita por empreitada (com colhedeira), em terra de $2 \mathrm{a}$., comprodutividade es perada de $80 \mathrm{sc}$. de $60 \mathrm{~kg} /$ alqueire;

$x_{05}=$ Soja II plantado em outubro, colheita por empreitada (com colhedeira), em terra de la., com produtividade es perada de $85 \mathrm{sc}$. de $60 \mathrm{~kg} / \mathrm{alque}$ ire;

$x_{06}=$ Algodão plantado em outubro, colheita por empreitada (manual), em terra de $1 \mathrm{a}$, com adubação em cobertura e com produtividade esperada de 300 arrobas (@)/alqueire;

$\mathrm{x}_{07}=$ Amendoim $\mathrm{I}$ plantado em outubro, colheita por empreitada (com colhedeira), em terra de $2 \mathrm{a}$, com produtividade es perada de $200 \mathrm{sc}$. de $25 \mathrm{~kg} / \mathrm{alqueire;}$

$\mathrm{x}_{08}=$ Amendoim II plantado em outubro, colheita por empreitada (com colhedeira), em terra de $1 \mathrm{a}$., com produtividade esperada de $220 \mathrm{sc}$. de $25 \mathrm{~kg} / \mathrm{alqueire;}$

$x_{09}=$ Milho I (produtividade baixa) plantado em outubro, com colheita manual, em terra de $2 \mathrm{a}$. , com tração motomecan $\underline{i}$ zada, com adubação em cobertura e com produtividade es- 
perada de $80 \mathrm{sc}$. de $60 \mathrm{~kg} / \mathrm{alqueire;}$

$\mathrm{x}_{10}=$ Milho II (produtividade baixa) plantado em outubro, com colheita manual empreitada, em terra de $2 \mathrm{a}$, com tração motomecanizada, sem adubação em cobertura e com pro dutividade esperada de $80 \mathrm{sc}$. de $60 \mathrm{~kg} / \mathrm{alqueire;}$

$x_{11}=$ Milho III (produtividade baixa) plantado em outubro, com colheita manual, em terra de 2a., tração animal pa$\mathrm{ra}$ as operações riscação, adubação e plantio, com aduba ção em cobertura e produtividade esperada de $80 \mathrm{sc}$. de $60 \mathrm{~kg} / \mathrm{alqueire;}$

$\mathrm{x}_{12}=$ Milho IV (produtividade baixa) plantado em novembro, com colheita manual, em terra de $2 \mathrm{a}$., com tração motome canizada, com adubação em cobertura e produtividade esperada de $80 \mathrm{sc}$. de $60 \mathrm{~kg} / \mathrm{alqueire;}$

$\mathrm{x}_{13}=$ Milho $\mathrm{V}$ (produtividade alta) plantado em novembro, com colheita manual, em terra de $1 \mathrm{a}$. , com tração motomecan $\underline{i}$ zada, sem adubação em cobertura e com produtividade esperada de $120 \mathrm{sc}$. de $60 \mathrm{~kg} / \mathrm{alqueire;}$

$\mathrm{X}_{14}=$ Milho VI (produtividade alta) plantado em outubro, colheita por empreitada (colhedeira e mão-de-obra), tração motomecanizada, em terra de $1 \mathrm{a}$., com adubação em cobertura e com produtividade esperada de $140 \mathrm{sc}$. de $60 \mathrm{~kg} / \mathrm{al}$ queire; 
$x_{15}=$ Café I (manutenção do cafezal) com produtividade espera da de $72 \mathrm{sc}$. de $40 \mathrm{~kg}$ de café em côco;

$X_{16}=$ Café II correspondente a investimento de café ou formação de novos cafezais;

$\mathrm{X}_{17}=$ Laranja $\mathrm{I}$ (manutenção do laranjal) com produtividade es perada de $1.000 \mathrm{cx} .{ }^{3}$ de $40 \mathrm{~kg} /$ alqueire;

$X_{18}=$ Laranja II correspondente a investimento em laranja ou formação de novos laranjais;

$\mathrm{X}_{19}=$ Pastagem $\mathrm{I}$, manutenção (roçada) da pastagem natural;

$\mathrm{X}_{20}=$ Pastagem II, correspondente a investimento em pastagem artificial;

$X_{21}=$ Pastagem III, correspondente a manutenção da pastagem artificial atual;

$x_{22}=$ cria, recria e engorda de suinos;

$x_{23}$ = bovinocultura ou produção de gado de corte (cria);

$x_{24}$ a $x_{28}=$ contratação de mão-de-obra nos cinco períodos;

${ }^{3} \mathrm{cx} .=$ caixas 
$\mathrm{X}_{29}$ a $\mathrm{X}_{32}=$ compra de fertilizantes $\left(\mathrm{N} / \mathrm{P}_{2} \mathrm{O}_{5} / \mathrm{K}_{2} \mathrm{O}\right)$ e de calcáreo, por tonelada dos elementos;

$x_{33}=$ crédito para fertilizante e calcáreo;

$\mathrm{X}_{34}=$ crédito para arroz I e II;

$X_{35}=$ crédito para arroz III;

$\mathrm{X}_{36}=$ crédito para soja I e II;

$x_{37}=$ crédito para algodão;

$X_{38}=$ crédito para amendoim I e II;

$\mathrm{X}_{39}=$ crédito para milho I a IV;

$\mathrm{X}_{40}$ e $\mathrm{X}_{41}=$ crédito para milho $\mathrm{V}$ e $\mathrm{VI}$;

$\mathrm{x}_{42}=$ crédito para café;

$x_{43}=$ crédito para laranja;

$x_{44}=$ venda de milho;

$\mathrm{x}_{45}=$ compra de milho;

$x_{46}$ a $x_{49}=$ transferência de recursos de um período para o seguinte; 
$\mathrm{X}_{50}$ a $\mathrm{X}_{54}=$ pagamento de tratorista nos cinco períodos;

$\mathrm{X}_{55}=$ gastos com empreita mecânica;

$\mathrm{X}_{56}=$ gastos com empreita manual.

Estas atividades propostas no problema competi ram pelos mesmos fatores de produção disponíveis na propriedade agrícola típica. Estes recursos aparecem na forma de restrições e correspondem aos valores do vetor b na equação 2 .

Antes de definir as restrições do modelo convém mencionar alguma coisa sobre a qualidade da terra encontrada na região. A terra foi classificada em terra de 1a. e de 2 a., de acordo com a fertilidade natural, características físicas e grau de intensidade permitidas no seu cultivo. Os agricultores indicaram as frações de cada solo existentes em suas propriedades.

A restrição mão-de-obra comum utilizada nạ tạ refas de capina, plantio, cultivo, colheita e outros tratos culturais foram a familiar e a assalariada. A mão-de-obra do tratorista foi considerada separada da restrição anterior devido aos preços (salários) diferenciados.

As disponibilidades dos fatores dos quais o ve tor b foi composto foram as seguintes: 


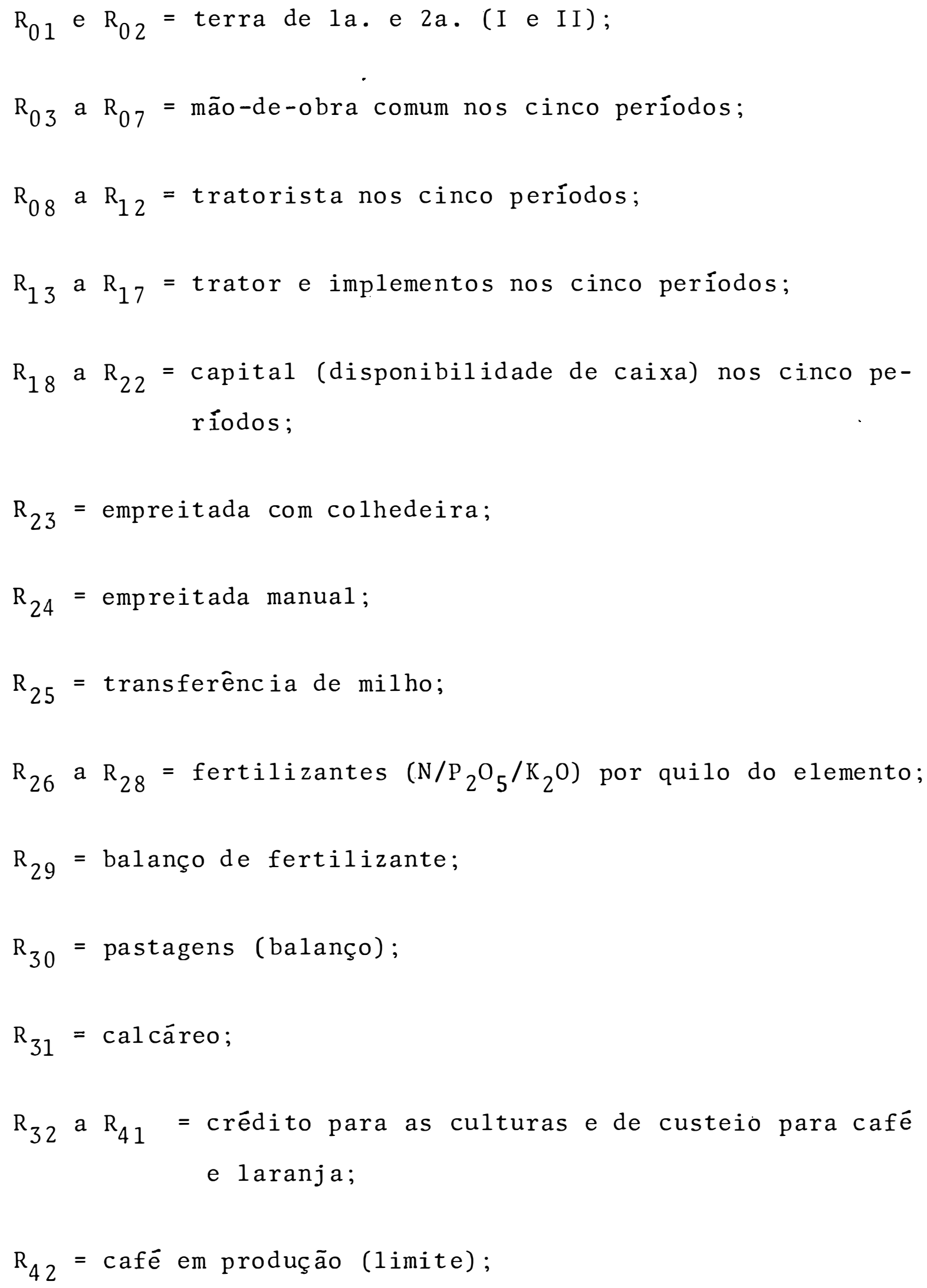


$\mathrm{R}_{43}=1 \operatorname{aranja}$ em produção (1 imite).

Em seguida sao apresentadas as tabelas de valor presente anualizado para as atividades de investimento em café, laranja e pastagem artificial. Deve-se enfatizar que o modelo é estático embora utilize elementos dinâmicos como a expectativa da inflação e a subdivisão do ano agrícola em diferentes períodos.

Para a atividade investimento em café ou forma ção de novos cafezais $\left(X_{16}\right)$ foi necessário fazer o cálculo do valor presente anualizado (ano típico), usando o seguinte pro cedimento (tabela 4): o período de planejamento foi de vinte e quatro anos a partir da formação de um alqueire de café; a produtividade do café em côco em sacas de $40 \mathrm{~kg}$ cresce a partir do $2^{\circ}$ ano, atinge o máximo no quinto ano e se torna cí clico daí em diante (um ano bom - 96 sacas/alqueire seguido de um ruim - 48 sacas/alqueire); o preço médio esperado foi de Cr $\$ 800,00 /$ saca; a receita bruta que é igual a produtividade vezes o preço médio esperado em cada ano foi calculada a partir do $2^{\circ}$ ano; a despesa do $1^{\circ}$ ao $5^{\circ}$ ano foi conseguida através das tabelas de "exigência de fatores e custo operacio nal na formação do cafezal" (ver Apêndice B), onde, para o 19 ano do custo operacional total foram tiradas as despesas com mão-de-obra e fertilizantes e juros bancários, as quais são consideradas separadamente; a partir do $5 \stackrel{\circ}{\text { ano }}$ o custo de manutenção foi considerado o mesmo até o final do período; a 
receita 1 iquida foi igual a receita bruta menos a despesa em cada ano; foi usada a taxa de desconto de 6\% ao ano, no cá1culo do Valor Líquido Presente (V.L.P.) das margens brutas.

De acordo com a experiência do agricultor, foram considerados quatro anos de perdas por efeitos de geadas durante o horizonte de planejamento da cultura (25 anos). Do V.L.P. total foram eliminados os retornos de quatro anos centrais $(\operatorname{Cr} \$ 198.850,40)$. Usando a fórmula descrita em NORONHA (1981) calcula-se a receita 1 íquida anualizada ou receita típica de cada ano multiplicando-se o V.L.P. pelo fator k:

$$
\begin{aligned}
& k=\frac{i(1+i)^{t}}{(1+i)^{t}-1}=\text { coeficiente de recuperação de capital } \\
& i=\text { taxa de juros }(6 \%) \text {; } \\
& \text { e } t=25 \text { anos. } \\
& k=\frac{0,06(1,06)^{25}}{(1,06)^{25}-1} \cong 0,08
\end{aligned}
$$

e a renda 1 íquida do ano típico de café, por exemplo, è igual a $0,08 \times \operatorname{Cr} \$ 198.850,40 \equiv \operatorname{Cr} \$ 15.900,00$. Este foi o resultado usado na Função Objetivo como a margem bruta associada à atividade de investimento em café. 
Tabela 4. Cronograma Físico e Financeiro de 1 Alqueire de Ca fé ( 2.400 covas), nos 24 Anos a Partir de sua Formaçāo, com Controle de "Ferrugem", Regiāo de·Ribeirão Preto, SP,, a Pre ços Médios do Ano Agrícola 1978/79.

\begin{tabular}{|c|c|c|c|c|c|c|}
\hline Anos & $\begin{array}{l}\text { Produçāo } \\
\text { de café } \\
\text { em côco } \\
\text { sc.40 kg }\end{array}$ & $\begin{array}{l}\text { Receita }{ }^{2} \\
\text { bruta } \\
\text { Cr } \$\end{array}$ & $\begin{array}{l}\text { Despesa } \\
\text { Cr } \$ / \text { ano. }\end{array}$ & $\begin{array}{l}\text { Receita } \\
\text { Líquida' } \\
\text { Cr\$ }\end{array}$ & $\begin{array}{c}\text { Fator } \\
\text { de. } \\
\text { desconto } \\
:(68)\end{array}$ & $\begin{array}{l}\text { Valor } \\
\text { Líquido } \\
\text { presente }\end{array}$ \\
\hline 0 & & & $13.307,50$ & $-13.307,50$ & 1,00 & $-13.307,50$ \\
\hline 1 & & $-\cdots$ & $8.619,10$ & $-8.619,10$ & 0,94 & $-8.101,95$ \\
\hline 2 & 20 & $16.000,00$ & $13.102,10$ & $2.897,90$ & 0,89 & $2.579,13$ \\
\hline 3 & 36 & $28.800,00$ & $17.313,40$ & $11.486,00$ & 0,84 & $9 . .648,74$ \\
\hline 4 & 72 & 57.600 .00 & 23.268 .60 & $33.631,40$ & 0,79 & $26.568,81$ \\
\hline 5 & 96 & $76: 800,00$ & $33.485,20$ & $43.314,80$ & 0,75 & $32.486,10$ \\
\hline 6 & 48 & $38.400,00$ & $33.485,20$ & $4.914,80$ & 0,70 & $3.440,36$ \\
\hline 7 & 96 & $76.800,00$ & $33.485,20$ & $43.314,80$ & 0,67 & $29.020,92$ \\
\hline 8 & 48 & $38.400,00$ & $33.485,20$ & $4.914,80$ & 0,63 & $3.096,32$ \\
\hline 9 & 96 & $76.800,00$ & $33.485,20$ & $43.314,80$ & 0,59 & $25.555,73$ \\
\hline 10 & 48 & $38.400,00$ & $33.485,20$ & $4.914,80$ & $0 ; 56$ & $2.752,29$ \\
\hline 11 & 96 & $76.800,00$ & $33.385,20$ & $43.314,80$ & 0,53 & $22.956,84$ \\
\hline 12 & 48 & $38.400,00$ & $33.485,20$ & $4.914,80$ & 0,50 & $2.457,40^{\star}$ \\
\hline 13 & 96 & $76.800,00$ & $33.485,20$ & $43.314,80$ & 0,47 & $20.357,96^{*}$ \\
\hline 14 & 48 & $38.400,00$ & $33.485,20$ & 4.914 .80 & 0,44 & $2.162,51$ \\
\hline 15 & 96 & $76.800,00$ & $33.485,20$ & $: ? .314,80$ & 0,42 & $18.192,22^{*}$ \\
\hline 16 & 48 & $38.400,00$ & $33.485,20$ & $4.914,80$ & 0,39 & $1.916,77^{\star}$ \\
\hline 17 & 96 & $76.800,00$ & $33.485,20$ & $43.314,80$ & 0,37 & $16.026,48$ \\
\hline 18 & 48 & $38.400,00$ & $33.485,20$. & $4.914,80$ & 0,35 & $1.720,18$ \\
\hline 19 & 96 & $76.800,00$ & $33.485,20$ & $43.314,80$ & 0,33 & $14.293,88$ \\
\hline 20 & 48 & $38.400,00$ & $33.485,20$ & $4.914,80$ & 0,31 & $1.523,59$ \\
\hline 21 & 96 & $76.800,00$ & $33.485,20$ & $43, .314,80$ & 0,29 & $12.561,29$ \\
\hline 22 & 48 & $38.400,00$ & $33.485,20$ & $4.914,80$ & 0,28 & $1.376,14^{\circ}$ \\
\hline 23 & 96 & $76.800,00$ & $33.485,20$ & $43.314,80$ & 0,26 & $11.261,85$ \\
\hline 24 & 48 & $38.400,00$ & $33.485,20$ & $4.914,80$ & 0,25 & $1.228,70$ \\
\hline $\boldsymbol{\Sigma}$ & & & & & & $241.774,76$ \\
\hline
\end{tabular}

a) Preço médio esperado de Cr $\$ 800,00 / \mathrm{sc}$.

Quatro anos de geada.

Fonte: Dados da amostra. 
Para o cálculo do valor presente da receita $1 \underline{i}$ quida anualizada (tabela 5) da atividade investimento em laranja ou formação de novos laranjais $\left(\mathrm{X}_{18}\right)$ foi usado o mesmo procedimento do investimento em café, exceto pela pressuposição de ocorrências de dano por geadas.

Quanto ao cálculo do custo anualizado da atividade investimento em pastagem artificial $\left(\mathrm{X}_{20}\right)$, pode-se verificar na tabe 1a 6 que foram considerados cinco anos para o período de planejamento. 0 item despesa constou do custo de formação no $1^{\circ}$ ano (despesas com máquinas, animais e implementos, sementes, defensivos e depreciação das máquinas) e da manutenção do $2^{\circ}$ até o $5^{\circ}$ ano (onde foi considerado o capital nos períodos III e IV da pastagem III e as despesas com mão-de-obra do tratorista).

Como foi anteriormente explicado, usando o coeficiente de recuperação de capital igual a 0,28 (k) e multiplicando-se pelo V.L.P. obteve-se o custo anualizado do investimento em pastagem artificial $(-\operatorname{Cr} \$ 4.422,69)$.

0 destino da produção de suínos (cria, recria e engorda $-\mathrm{x}_{22}$ ) da maioria das propriedades agrícolas da amostra foi principalmente para consumo (cerca de $53 \%$ ), $40 \%$ para consumo e venda e 7\% só para venda.

A tabela 7 mostra a composição de uma "unidade -porca", com os requerimentos correspondentes, custos e rece $\underline{i}$ tas (valores imputados) de suínos. A receita foi imputada porque a maioria das propriedades agrícolas consomem a sua pró 
Tabela 5. Cronograma Físico e Financeiro de 1 Alqueire de La ranja (5.000 pés) Durante o Período de Planejamento de 24 Anos, a Partir de sua Formaçāo,. com Tecnologia Recomendada Para a Regiāo de Ribeirão Preto, SP, a Prieços Médios do Ano Agrícola 1978/79.

\begin{tabular}{|c|c|c|c|c|c|c|}
\hline Anos & $\begin{array}{l}\text { Produçāo } \\
\text { de laranja } \\
\text { caixa de } \\
40 \mathrm{~kg}\end{array}$ & $\begin{array}{c}\text { Receita } \\
\text { bruta } \\
\text { Cra }\end{array}$ & $\begin{array}{l}\text { Despesa } \\
\text { Cr } \$ / a n o\end{array}$ & $\begin{array}{l}\text { Receita } \\
\text { Líquida } \\
\text { Cr\$ }\end{array}$ & $\begin{array}{l}\text { Fator } \\
\text { de } \\
\text { desconto } \\
(6 q)\end{array}$ & $\begin{array}{c}\text { Valor } \\
\text { Líquido } \\
\text { presente }\end{array}$ \\
\hline 0 & & & $14.961,03$ & $-14.961,03$ & 1,00 & $-14.961,03$ \\
\hline 1 & & & $7.653,85$ & $-7.653,85$ & 0,94 & $-7.194,62$ \\
\hline 2 & 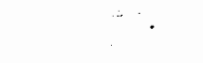 & & $9.975,65$ & $-9.975,65$ & 0,89 & $-8.878,33$ \\
\hline 3 & 500 & $25.500,00$ & $14.015,85$ & $11.484,15$ & 0,84 & $9.646,69$ \\
\hline 4 & 1.000 & $51.000,00$ & $19.568,30$ & $31.431,70$ & 0,79 & $24.831,04$ \\
\hline 5 & 1.000 & $51.000,00$ & $19.568,30$ & $31.431,70$ & 0,75 & $23.573,78$ \\
\hline 6 & 1.000 & $51.000,00$ & $19.568,30$ & $31.431,70$ & 0,70 & $22.002,19$ \\
\hline 7 & 1.000 & $51.000,00$ & $19.568,30$ & $31.431,70$ & 0,67 & $21.059,24$ \\
\hline 8 & 1.000 & $51.000,00$ & $19.568,30$ & $31.431,70$ & 0,63 & $19.801,97$ \\
\hline 9 & 1.000 & $51.000,00$ & $19.568,30$ & $31.431,70$ & 0,59 & $18.544,70$ \\
\hline 10 & 1.000 & $51.000,00$ & $19.568,30$ & $31.431,70$ & 0,56 & - $17.601,75$ \\
\hline 11 & 1.000 & $51.000,00$ & $19.568,2 n$ & $31.431,70$ & 0,53 & $16.658,80$ \\
\hline 12 & 1.000 & $51.000,00$ & $19.568,30$ & $31-431,70$ & 0,50 & $15.715,85$ \\
\hline 13 & 1.000 & $51.000,00$ & $19.568,30$ & $31.431,70$ & 0,47 . & $14.772 ; 90$ \\
\hline 14 & 1.000 & $51.000,00$ & $19.568,30$ & $31.431,70$ & 0,44 & $13.829,95$ \\
\hline 15 & 1.000 & $51.000,00$ & $19.568,30$ & $31.431,70$ & 0,42 & $13.201,31^{\circ}$ \\
\hline 16 & 1.000 & $51.000,00$ & $19.568,30$ & $31.431,70$ & 0,39 & $12.258,36$ \\
\hline 17 & 1.000 & $51.000,00$ & $19.568,30$ & $31.431,70$ & 0,37 & $11.629,73$ \\
\hline 18 & 1.000 & $51.000,00$ & $19.568,30$ & $31.431,70$ & 0,35 & $11.001,10$ \\
\hline 19 & 1.000 & $51.000,00$ & $19.568,30$ & $31.431,70$ & 0,33 & $10.372,46$ \\
\hline 20 & 1.000 & $51.000,00$ & $19.568,30$ & $31.431,70$ & 0,31 & $9.743,83$ \\
\hline 21 & 1.000 & $51.000,00$ & $19.568,30$ & $31.431,70$ & 0,29 & $9.115,19$ \\
\hline 22 & 1.000 & $51.000,00$ & $19.568,30$ & $31.431,70$ & 0,28 & $8.800,88$ \\
\hline 23 & 1.000 & $51.000,00$ & $19.568,30$ & $31.431,70$ & 0,26 & $8.172,24$ \\
\hline $\boldsymbol{\Sigma}$ & & & & & & $=281.300,00$ \\
\hline
\end{tabular}

a/ Preço médio da caixa de 1 aranja recebido pelos Agricultores de Ribeirão Preto, SP, de $\operatorname{Cr} \$ 51,00 / \mathrm{cx}$.

Fonte: I.E.A. - Informações Econômicas 7/1979. 
pria produção e usam parte da sua produção de milho para alimentação dos animais.

Tabela 6. Cronograma Físico e Financeiro de 1 Alqueire de Pastagem Artificial Durante o Horizonte de Planejamento de 5 Anos a Partir de sua Formação, Região de Ribeirão Preto, SP,. Ano Agrícola 1978/79.

\begin{tabular}{cccc}
\hline Anos & Despesa & $\begin{array}{c}\text { Fator de } \\
\text { desconto } \\
(6 \%)\end{array}$ & V.L.P. \\
\hline 19 & $-7.816,22$ & 1,00 & $-7.816,22$ \\
$2 \circ$ & $-2.306,10$ & 0,94 & $-2.167,73$ \\
$3 \bullet$ & $-2.306,10$ & 0,89 & $-2.052,43$ \\
49 & $-2.306,10$ & 0,84 & $-1.937,12$ \\
$5 \bullet$ & $-2.306,10$ & 0,79 & $-1.821,82$ \\
\hline$\Sigma$ & & & $-15.795,32$ \\
\hline
\end{tabular}

Fonte: Dados da amostra.

Alguns dados para a estimação destes coeficien tes foram tirados de PËRES (1976).

A idade de'venda dos animais variou entre 10 - 12 meses e o preço da arroba (@) foi de $\operatorname{Cr} \$ 361,00$ (média entre junho/1978 e valor esperado em junho/1979). 
Tabéla 7. Composição do Rebanho de Suinos Tipo Banha, Despesas Requeridas e Retorno Anual - $1978 / 79$

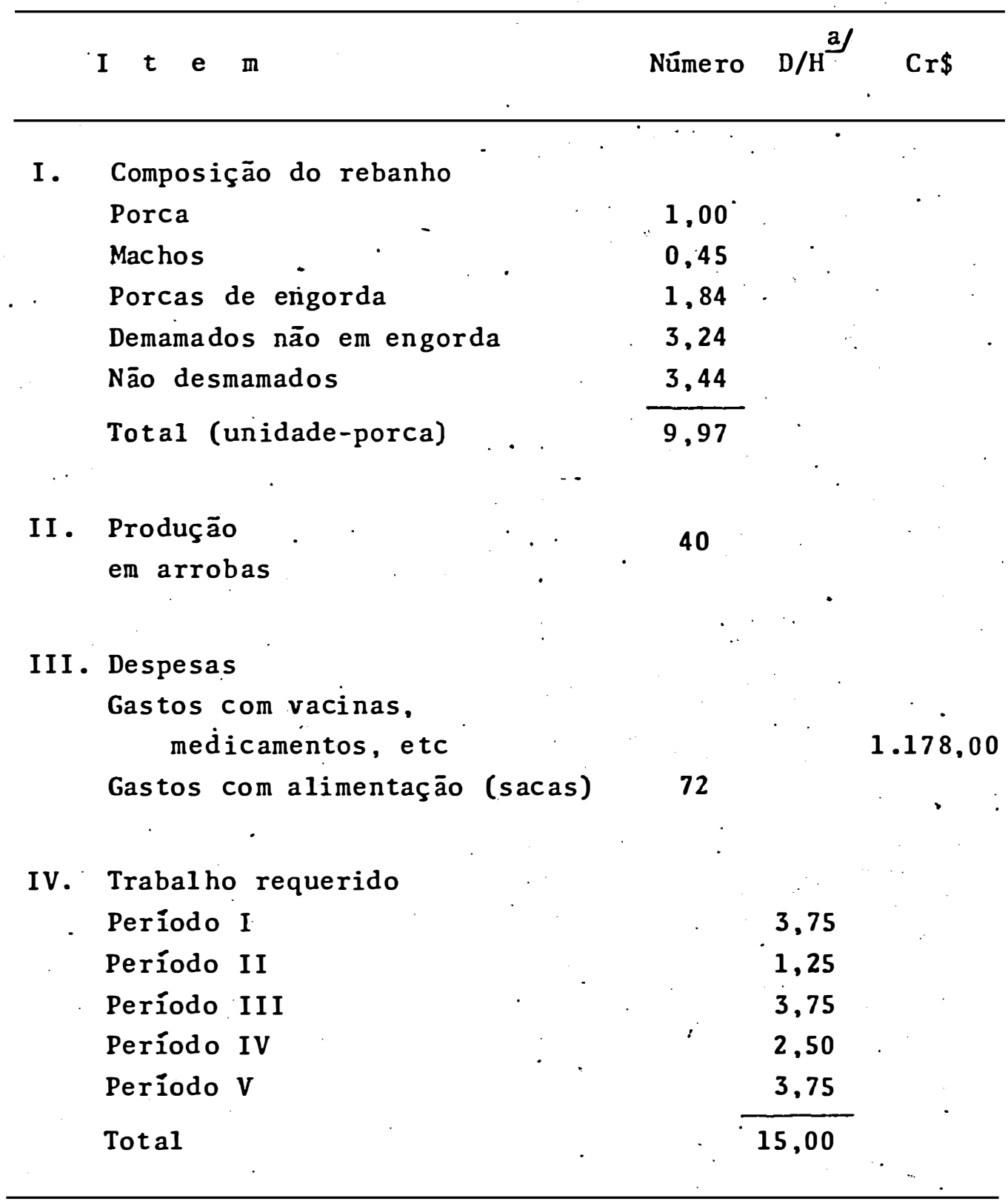

a/ D/H significa dias/homem.

Fonte: Dados da amostra. 
A taxa de consumo do milho por quilo ganho de peso-vivo foi de $7,2 \mathrm{~kg}$. O consumo de milho por unidade por ca foi de 72 sacas. Portanto, a produção $(600 \mathrm{~kg}$ de carne ou 40 @/unidade porca) multiplicado pelo preço médio da arro ba foi igual a receita esperada imputada de cerca de $\operatorname{Cr} \$ 14.440,00$.

Os gastos com vacinas e medicamentos para suínos foram distribuídos unifornemente ao longo do ano. Os gastos com alimentação dos suínos foram computados da seguinte mane $\underline{i}$ ra: 72 sacas de milho vezes o preço médio por saca de milho.

Admitiu-se que as despesas com vacinas, medica mentos, etc, somaram $10 \%$ dos valores de alimentação.

Portanto, esses gastos totalizaram $\operatorname{Cr} \$ 1.178,00$. Foi feita a seguinte consideração para a distribuição destes gastos ao longo do ano: $25 \%$ para cada período de três meses (I, III e V), $17 \%$ para o período IV e $8 \%$ para o período II que corresponde ao mês de outubro.

Os requerimentos de trabalho foram considerados em 15 dias/homem por ano e repartidos linearmente nos diversos períodos.

A atividade gado de corte consta de três subdivisões: cria, recria e engorda. Geralmente, os agricultores se es pecializam em una dessas atividades ou numa combinação delas.

Inicialmente, foi feita a tentativa de identificar na amostra quais as atividades mais usadas entre os 
agricultores da região. Foi constatado que engorda de bovinos não era uma atividade comum e que, recria era mais usada em pequena escala. A atividade cria de bovinos foi a mais encontrada na amostra.

A tabela 8 mostra a composição do rebanho, a rece $\underline{i}$ ta esperada e o custo de produção por unidade animal. A pro dução de leite não foi de grande expressão, sendo considerada um subproduto da atividade cria de bovinos. Grande parte das propriedades agrícolas consomem a sua própria produção de leite, sobrando pouca quantidade para venda. 0 preço do litro de leite foi considerado (e imputado como $\operatorname{Cr} \$ 3,96$ no início e $\operatorname{Cr} \$ 5,86=1,48 \times 3,96$ no fim do período, sendo de $\operatorname{Cr} \$ 4,91 / 1$ itro o preço médio do ano agrícola 1978/79. A produção de le $\underline{i}$ te foi computada e adicionada à receita esperada da seguinte maneira: para cada unidade animal, 3 litros de leite por dia vezes 210 dias de lactação. Este resultado foi igual a $6301 \underline{1}$ tros anuais. Cada unidade-animal requer 3,6 alqueires de pas to por ano. Para calcular o valor dos insumos modernos desta atividade foi usado o mesmo procedimento da atividade ante rior (suínos), assim como também os coeficientes de mão-de-obra.

Foi adotada a mesma taxa de venda de animais velhos como taxa de reposição de bois e de vacas. Esta taxa vezes os respectivos preços destes animais (julho/1978) e vezes a taxa de inflação esperada para o período foram os outros valores incluídos no item despesas. 
Tabềla 8. Composição do Rebanho de Cria de Bovinos; Despesas Requeridas e. Retorno Anual - 1978/79
I $\quad t \quad e \quad m$
Número
$\mathrm{D} / \mathrm{H}$ a
$\operatorname{Cr} \$$

I. Produção de carne

Bezerros

Vacas magras

Boi velho

Total
0,62

0,17

0,01

0,80

6,30 (100 litros)

$$
\begin{array}{r}
1.489,50 \\
858,60 \\
149,10 \\
\hline 2.497,20
\end{array}
$$

$3.093,30$

III . Despesas

Insumos modernos

(vacinas, medica mentos, etc)

Reposição de bois 0,01

Reposição de vacas 0,20

$1.656,70$

IV. Trabalho requerido

Período I

Período II

Período I I

Período IV

Período V

Total
1,25

0,42

1,25

0,84

1,25

5,01

a/ D/H sïgnifica dias/homem.

Fonte: Dados da amostra. 
Por causa da falta de dados, o preço do boi ve 1ho foi considerado comó sendo o preço da vaca leiteira multí plicado por 1,8 (taxa de reposição). e pela taxa de inflação esperada.

O valor que entrou na Função Objetivo foi de Cr\$3.648,50 computado através da diferença entre a receita total/unidade-vaca e as despesas.

Os valores das atividades de crédito para cada cultura e para fertilizantes e calcáreo $\left(x_{33}\right.$ a $\left.x_{43}\right)$ foram calculados de acordo com as normas vigentes do Banco Central para a sa fra 1978/79: 60\% da produtividade de cada cultura vezes o respectivo preço mínimo.

'Para os financiamentos foram considerados juros de $17 \%$ ao ano sem capitalização. Fertilizantes não pagavam juros. Os reçursos permaneceram na mão do agricultor em média por 10 meses, correspondendo um juro efetivo de $14 \%$ no período.

A tabela 9 fornece de maneira detalhada os valores de crédito.

\subsection{Restrições (R.H.S.)}

$\mathrm{Na}$ equação 2 os valores do vetor b correspondem às limitações de recursos (R.H.S.) da propriedade agríco1a típica. 
Tabela 9. Crédito para Custeio, $1978 / 79$ Ribeirão Preto, SP

\begin{tabular}{lclc}
\hline Cultura & Produtividade & $\begin{array}{l}\text { Preço } \\
\text { Mínimo }\end{array}$ & $\begin{array}{c}\text { Adiantámento } \\
\text { 0,6 P.M. x Produtividade }\end{array}$ \\
\hline Arroz I & $56 \mathrm{sc} / 60 \mathrm{~kg}$ & $236,40 / \mathrm{sc}$ & $7.943,00$ \\
Arroz II & $56 \mathrm{sc} / 60 \mathrm{~kg}$ & $236,40 / \mathrm{sc}$ & $7.943,00$ \\
Arroz III & $66 \mathrm{sc} / 60 \mathrm{~kg}$ & $236,40 / \mathrm{sc}$ & $9.345,00$ \\
Soja I & $80 \mathrm{sc} / 60 \mathrm{~kg}$ & $150,00 / \mathrm{sc}$ & $7.200,00$ \\
Soja II & $85 \mathrm{sc} / 60 \mathrm{~kg}$ & $150,00 / \mathrm{sc}$ & $7.200,00$ \\
Milho I & $80 \mathrm{sc} / 60 \mathrm{~kg}$ & $108,00 / \mathrm{sc}$ & $4.406,00$ \\
Milho II & $80 \mathrm{sc} / 60 \mathrm{~kg}$ & $108,00 / \mathrm{sc}$ & $4.406,00$ \\
Milho III & $80 \mathrm{sc} / 60 \mathrm{~kg}$ & $108,00 / \mathrm{sc}$ & $4.406,00$ \\
Milho IV & $80 \mathrm{sc} / 60 \mathrm{~kg}$ & $108,00 / \mathrm{sc}$ & $4.406,00$ \\
Milho V & $140 \mathrm{sc} / 60 \mathrm{~kg}$ & $108,00 / \mathrm{sc}$ & $7.776,00$ \\
Milho VI & $140 \mathrm{sc} / 60 \mathrm{~kg}$ & $108,00 / \mathrm{sc}$ & $9.720,00$ \\
Algodão & $300 @$ & $134,00 /$ & $24.120,00$ \\
Amendoim I & $200 \mathrm{sc} / 25 \mathrm{~kg}$ & $108,00 / \mathrm{sc}$ & $12.960,00$ \\
Amendoim II & $220 \mathrm{sc} / 25 \mathrm{~kg}$ & $108,00 / \mathrm{sc}$ & $12.960,00$ \\
Café I & $72 \mathrm{sc} / 40 \mathrm{~kg}$ & $563,00 / \mathrm{sc}$ & $12.960,00$ \\
Laranja I & $1.000 \mathrm{cx}$. & $40,00 / \mathrm{cx}$ & $12.000,00$ \\
\hline
\end{tabular}

Fonte: Manual de Crédito Rural - BACEN. 
Para o recurso Terra I estavam disponíveis 22 alqueires de terra e para o recurso Terra II, 10 alqueires.

A mão-de-obra familiar ou comum em termos de dias/homem foi considerada em 645 dias de trabalho por ano, que foram subdivididos nos cinco períodos de acordo com a disponibilidade de cada período. A maior ou menor disponibi lidade dependia das condições climáticas. Foi usada a seguinte relação para comparar o trabalho do homem com o da muther e o da criança: a mão-de-obra feminina correspondeu a $75 \%$ da masculina e a da criança foi comparada a $50 \%$ da masculina (PÉRES, 1976) (admitindo que as crianças trabalhavam 8 horas diárias). Trabalhadores adicionais poderiam ser contratados mediante pagamento de diária (do fluxo de caixa no período).

O trabalho do tratorista não constou do R.H.S. porque pressupõe-se que seria contratado, assim como os recur sos colhedeira e mão-de-obra para colheita.

Os dados das horas disponiveis de trabalho dos fatores de produção oferecidos pela propriedade agrícola, em cada período foram conseguidos de AZEVEDO FILHO e PÉRES (1981). Estes autores consideraram o número de dias nublados ou chuvo sos, que impediam a execução de determinadas tarefas, ao calcularem os dias disponiveis de trabalho.

A propriedade agrícola considerada dispunha so mente de um trator VALMET 65 (56 HP) que correspondeu a 660 ho 
ras de trabalho para o Período I, 200 para o Período II, 450 para o Período III, 260. para o Período IV e 582 para o Período V.

A disponibilidade de capital operacional foi inicialmente fixada em $\operatorname{Cr} \$ 10.000,00$ no período inicial (I) do ano agrícola. Posteriormente este valor foi aumentado, porque não foi possivel conseguir uma boa estimativa da disponibilidade de caixa no início do período.

Foi necessārio limitar a produção de café, de laranja e de área de pastagem por causa dos investimentos fe $\underline{i}$ tos anteriormente (existência de plantas em produção). Estes limites foram valores médios da amostra e corresponderam a 2,3 algueires para café, a 7,7 alqueires para laranja e a 9 alqueires de área para pastagem.

A matriz completa (inclusive com os vetores c e b) utilizada está apresentada no Apêndice A. 
5. RESULTADOS E CONCLUSÕES

A primeira parte deste capítulo trata da in trodução de risco no processo de tomada de decisão.

A segunda parte apresenta a(s) fronteira(s) ef $\underline{i}$ ciente(s) da propriedade típica dos agricultores da amostra e discute algumas implicações quanto às tecnologias de produção de milho, associadas a diferentes disponibilidades iniciais de capital operacional .

A última parte mostra as conclusões do estudo e dá recomendações para novos trabalhos.

\subsection{Introdução de risco.}

0 risco foi introduzido de acordo com as equações 8 a 12 (Cap. 2), ficando a matriz final com 61 colunas (atividades) e 49 linhas (restrições). Portanto, foram acres cidas mais cinco atividades $\left(x_{57}\right.$ a $\left.x_{61}\right)$ e cinco restrições 
$\left(\mathrm{R}_{44}\right.$ a $\left.\mathrm{R}_{48}\right)$ correspondentes aos desvios em relação à receita média dos cinco anos (1974 a 1978) de cada cultura (variável "proxy" para risco).

Como foi dito anteriormente, o modelo utilizado pressupõe risco somente do 1 ado do produto.

A atividade compra de milho foi considerada também como geradora de risco porque o milho comprado pela pro. priedade e usado como fator de produção de suínos seria adqui rido ao longo do período e por preços não conhecidos. Este risco foi medido pelos desvios em relação ao preço real médio esperado para 1979 .

A série de dados de receita por alqueire (produtividade vezes o preço médio recebido pelos agricultores) para a equação 13 foi expressa em termos dos preços reais esperados para 1979 de acordo com a equação descrita no ítem 4.1 do capítulo anterior. Os dados de produtividade para os três primeiros períodos foram obtidos de médias do Estado. Pa ra os outros dois períodos foram usados dados da DIRA de Ribeirão Preto. Por causa desta diferença de dados foi adotado o seguinte procedimento para se obter as receitas médias es peradas para os diversos níveis de produtividade. 0 primeiro passo foi calcular o coeficiente de correção que é igual ao valor da produtividade esperada (do questionário) na Região dividido pelo valor das médias de produtividade do Estado. Este coeficiente multiplicado pela série de dados de 
produtividade de cada período, serviu para corrigir os dados de produtividade obtidos das duas fontes. Este procedimento foi repetido para cadä atividade (cultura). As médias dos novos níveis de produtividade foram, assim, iguais às médias dos valores esperados na amostra. As receitas brutas foram calculadas tomando estes novos níveis de produtividade vezes os seus respectivos preços reais. Daí, finalmente, foram ob tidas as médias das receitas. Os desvios em relação a essas médias representam as medidas de risco. Quando séries maio res de dados são utilizados, as possíveis tendências destas sê ries devem ser eliminadas, se se admite um comportamento racional dos mercados (no sentido proposto por MUTH, 1961) como feito por PERES (1976).

Deve-se lembrar que para bovinos de corte (cria) e suínos tipo banha, foram admitidas produtividades fí sicas constantes.

Para medir o risco da atividade bovinocultura de corte (cria) também foi usado o desvio com relação à recẹi ta média. No cálculo da receita média foi usado o coeficien te de correção de preço o qual equivale ao preço real da arroba no período dividido pelo preço da arroba em maio de 1979 (seria muito difícil expressar a produção em termos de arroba por unidade animal). Foi conseguida somente a série de preços da arroba. Então, utilizou-se a produtividade física do ano de 1979 como sendo comum aos outros anos. A receita total por unidade-vaca para maio de 1979 (tabela 8, cap.4) 
foi a soma da produção de carne e da produção de leite (efetí vamente realizado ou imputado). Do produto desta receita to tal pelo coeficiente de correção de preço de cada ano agrícola foram obtidas as receitas reais de 1974 a 1978 , como se pode verificar na tabela 10. Desta estimativa obteve-se a receita média do período 1974 - 1978 .

Para a atividade suínos tipo banha foi usado outro procedimento para cálculo do risco. A produtividade fí sica considerada (constante) foi de 40 arrobas por unidade-animal (tabela 7, Cap. 4). A estimativa da receita real foi, portanto, o produto desta produtividade física vezes o preço real da arroba para cada período. A partir da receita média do período 1974/78 foram calculados os desvios com relação às mesmas, como nas demais culturas. Estes valores estão apresentados na tabela 11 .

\subsection{A fronteira eficiente}

Utilizando as equações 8 a 12 do Cap. 2, foram ge radas as fronteiras eficientes da fig. 5. Os pontos destas fronteiras são combinações de atividades que correspondem ao mínimo risco (função objetivo) necessārio para se conseguir determinado retorno (margem bruta). Como não era conhecido o valor do capital operacional disponível no início do período, para a propriedade física, foi necessário parametrizar este valor. 


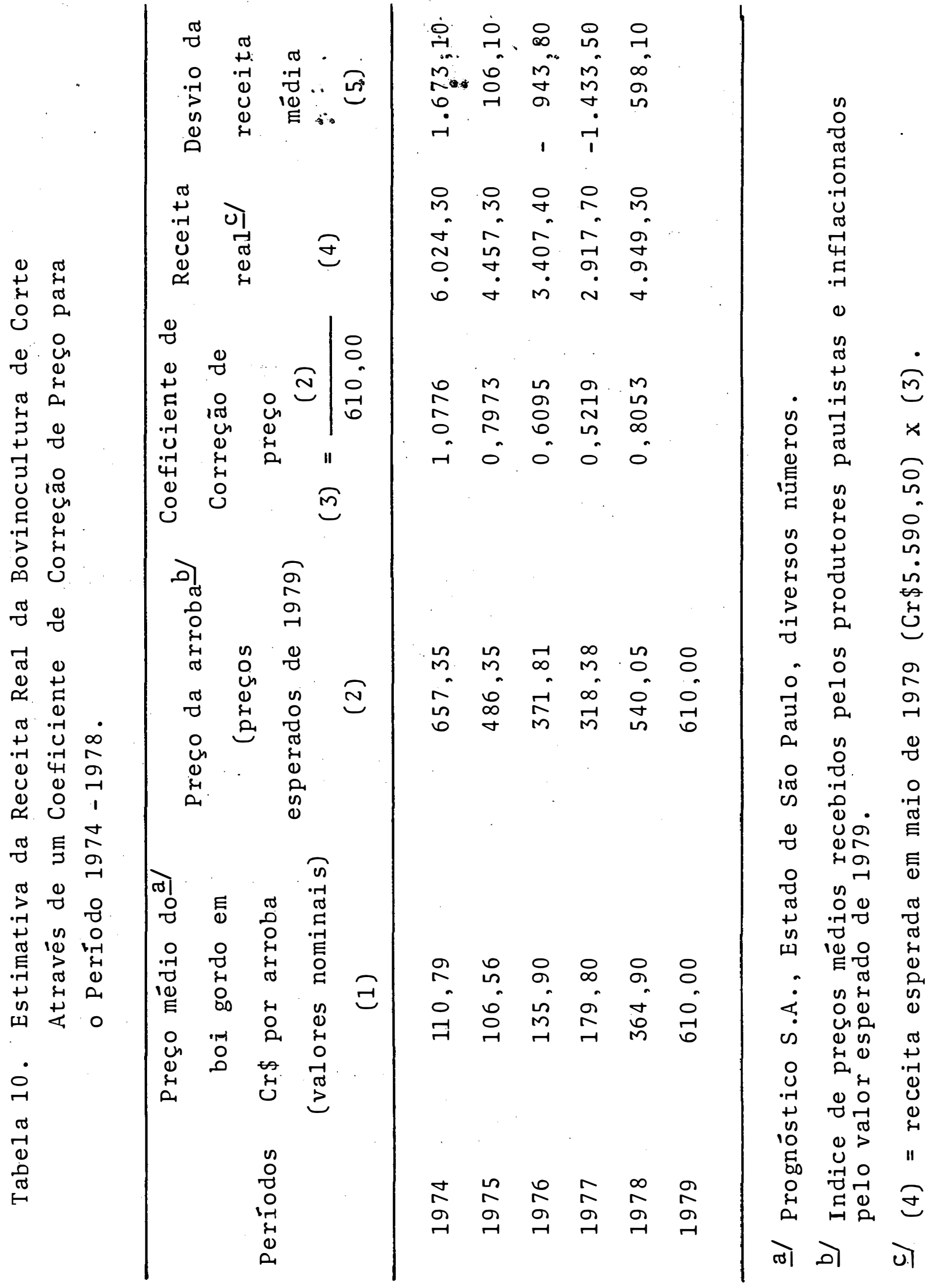




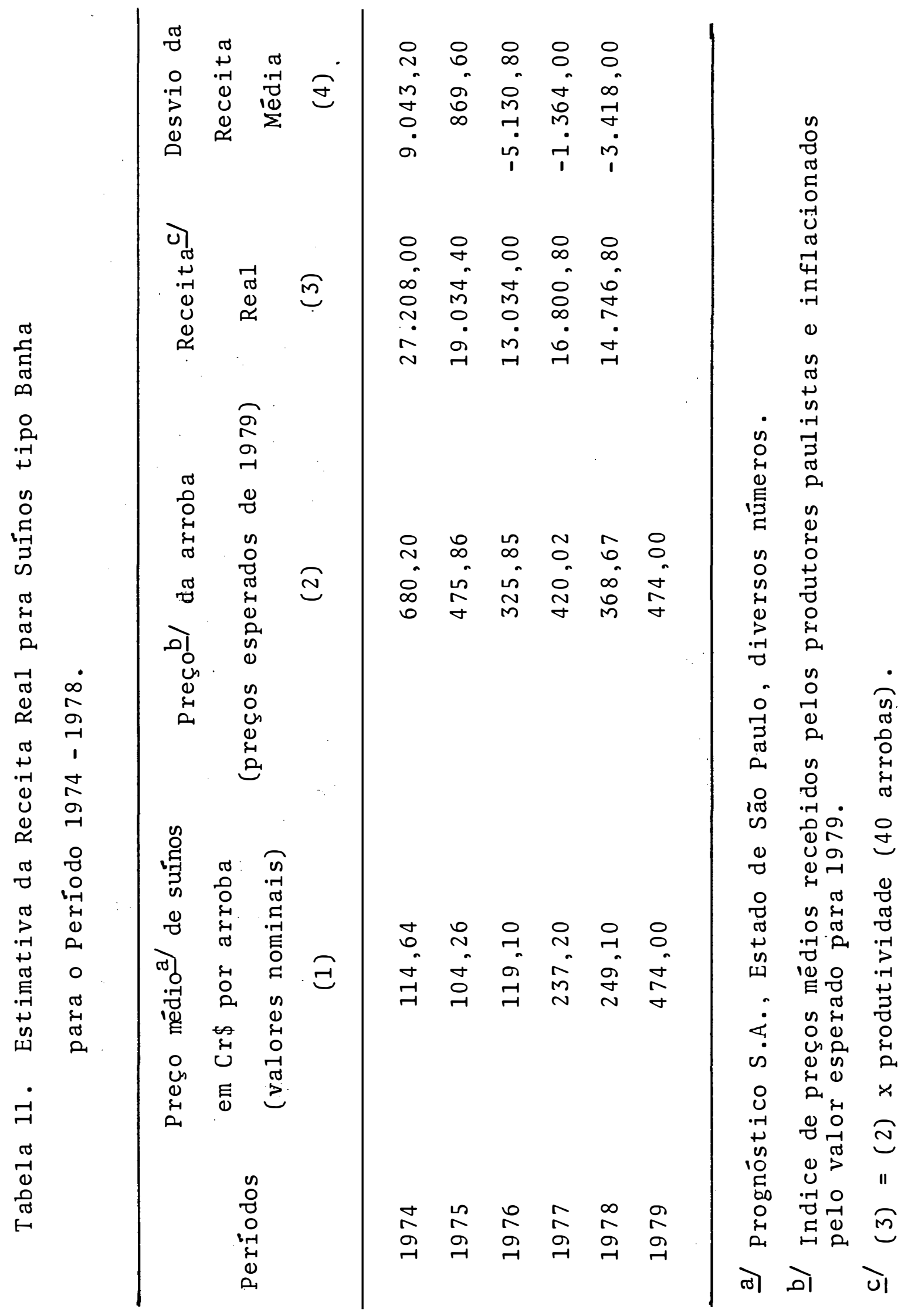


Inicialmente, o nível de disponibilidade de capital de giro foi arbitrariamente fixado em $\operatorname{Cr} \$ 10.000,00$. Pa ra este baixo nível de caixa o modelo indicou sobra de terra em qualquer nível de risco. Os dados da amostra indicam que o agricultor típico está utilizando toda a área de sua proprie dade. Portanto, pode-se inferir que ele não deve dispor somente desta quantidade de capital operacional. Como descrito anteriormente, o crédito rural financia somente $60 \%$ do preço mínimo estipulado pelo governo, vezes a produtividade esperada da cultura. Por esta razão acredita-se que a disponibilidade inicial de capital operacional da empresa agrícola seja maior que os $\operatorname{Cr} \$ 10.000,00$ considerados, já que o agricultor tem que utilizar capital próprio para financiar uma fração dos seus gastos. (Ano agricola 1978-79).

Posteriormente, foram fixados mais três níveis de disponibilidade de capital de giro: $\operatorname{Cr} \$ 30.000,00, \operatorname{Cr} \$ 60.000,00$ e $\operatorname{Cr} \$ 100.000,00$. Também, nestes casos, houve sobra de terra não cultivada na propriedade típica. Deve-se notar que não foi incluída na matriz a atividade de arrendamento de terra pa ra outros agricultores. Esta decisão deveu-se ao fato de não ter sido observado arrendamento na amostra.

Como a fronteira eficiente correspondente à dis ponibilidade inicial de capital operacional de $\operatorname{Cr} \$ 100.000,00$ não apresentava milho na composição das atividades, foi forçadạ a atividade de produção de suínos (X 22) num nível mínimo de 4 unidades porcas (Restrição 50). Como pode ser visto na 
tabela 12, as soluções indicaram quantidades decrescentes de terras ociosas, à medida que eram permitidas maiores quantidades de risco. O lucro (margem bruta) máximo possível com esta disponibilidade de capital foi de $\operatorname{Cr} \$ 577.883,00$ e o risco correspondente, de $128.821^{1}$. Com este nível de capital de giro o modelo indica que a medida que o risco incorrido vai au mentando, as culturas de algodão e laranja I (manutenção do lä ranjal) desaparecem, entrando soja de tecnologia mais baixa e amendoim de alta tecnologia. As atividades soja II (X05) de alta tecnologia e X15 (manutenção do cafezal) entram gradativa mente na solução à medida que maior risco é incorrido. Podese observar também que a um certo nível de renda e de risco $(\operatorname{Cr} \$ 576.000,00,113.000)$ a atividade amendoim de alta tecnologia desaparece.

Ainda, considerando uma disponibilidade de $\operatorname{Cr} \$ 100.000,00$ de capital inicial a cultura do milho aparece na fronteira eficiente somente com produtividade intermediária de 120 sc por alqueire, com um pico ao nível esperado de renda de

1 Este número, a soma dos desvios negativos com relação à mé dia ou valor esperado dos retornos das culturas, pode se $\bar{r}$ interpretado como um valor em cruzeiros ou pode ser transformado em desvio padrão us ando-se a fórmula $\sigma=A \sqrt{\frac{\pi s}{2(s-1)}}$ onde s é o número de observações e A o desvio absoluto como descrito em HAZELL (1971) . O desvio padrão é a medida ade quada quando se usa o enfoque desenvolvido por MARKOWIT $\bar{Z}$ (1952) e ampliado por TOBIN (1958). 


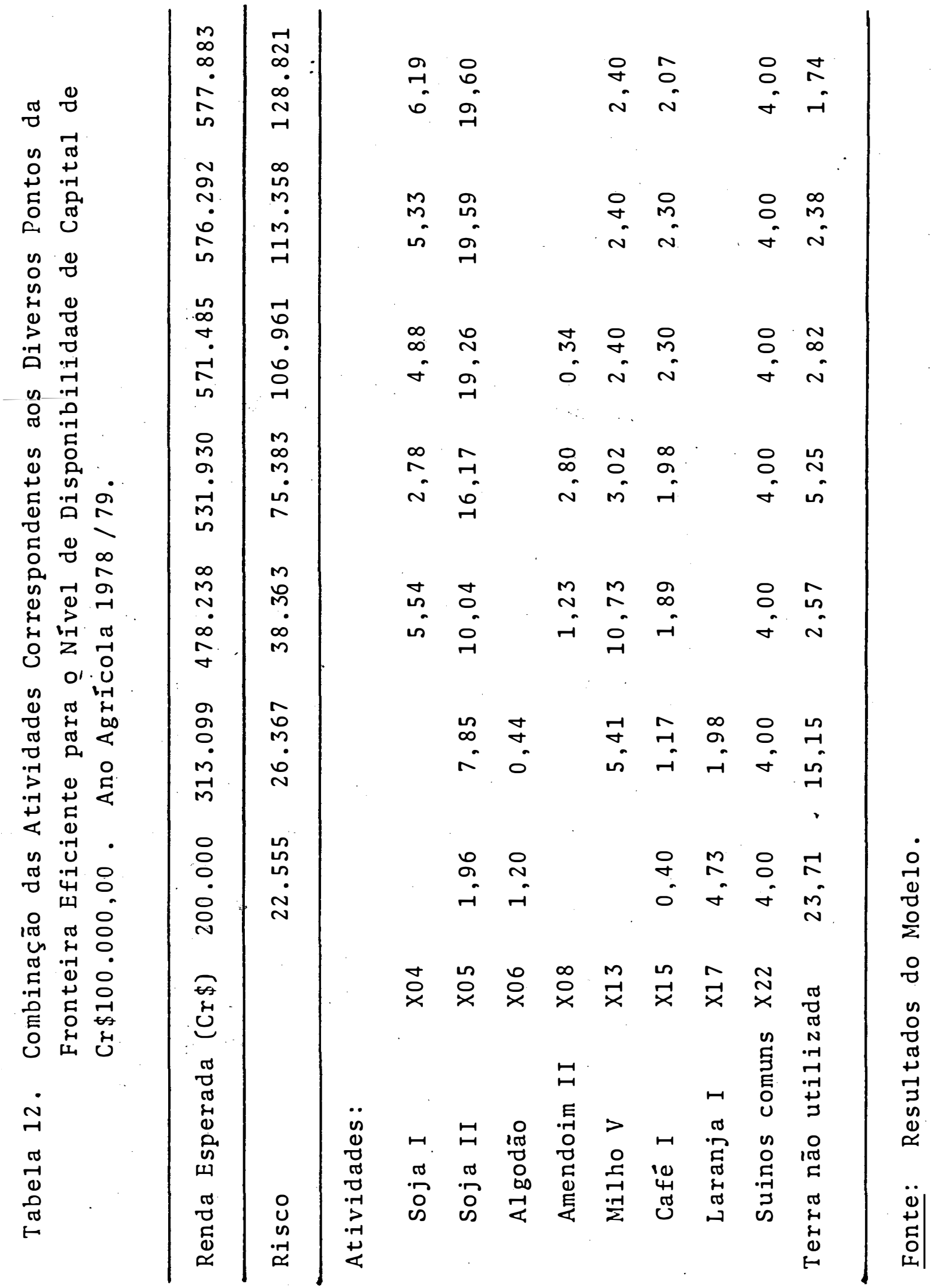


Cr $\$ 478.238,00$ e risco de 38.363 para, logo em seguida, decres cer com bastante intensidade, mantendo-se assim até o ponto correspondente da solução de máximo lucro. Aceitando-se como razoável a qualidade dos dados utilizados na construção da matriz dos coeficientes tecnológicos e os valores das receitas esperadas, pode-se inferir que a propriedade típica deve contar com mais de $\operatorname{Cr} \$ 100.000,00$ de capital operacional no início do período. Isto implica no acatamento da pressuposição implícita de que hã uma fiscalização eficiente na concessão e uso do crédito rural. Um outro aspecto relacionado com a fronteira eficiente da figura 5 deve ainda ser mencionado.

0 modelo descrito no Capítulo 2 (equações 8 a 12) permitia a produção, compra e venda de milho. Nada impedia a possibilidade do agricultor comprar e revender milho, in correndo em prejuízo monetário, como uma possibilidade de redu ção de risco. Como esta possibilidade foi extensivamente uti lizada decidiu-se, na ausência de explicações razoâveis para este fenômeno, permitir ao agricultor vender somente sua produ ção própria (Restrição 51). Mesmo assim, a baixos níveis de lucro, as soluções indicavam que o agricultor deveria vender sua produção e comprar o milho necessário à alimentação dos suínos.

Para o capital operacional inicial de $\operatorname{Cr} \$ 200.000,00$ foram considerados dois casos, descritos nas tabelas 13 e 14 . No primeiro caso, não foi forçada a produção de suínos e 


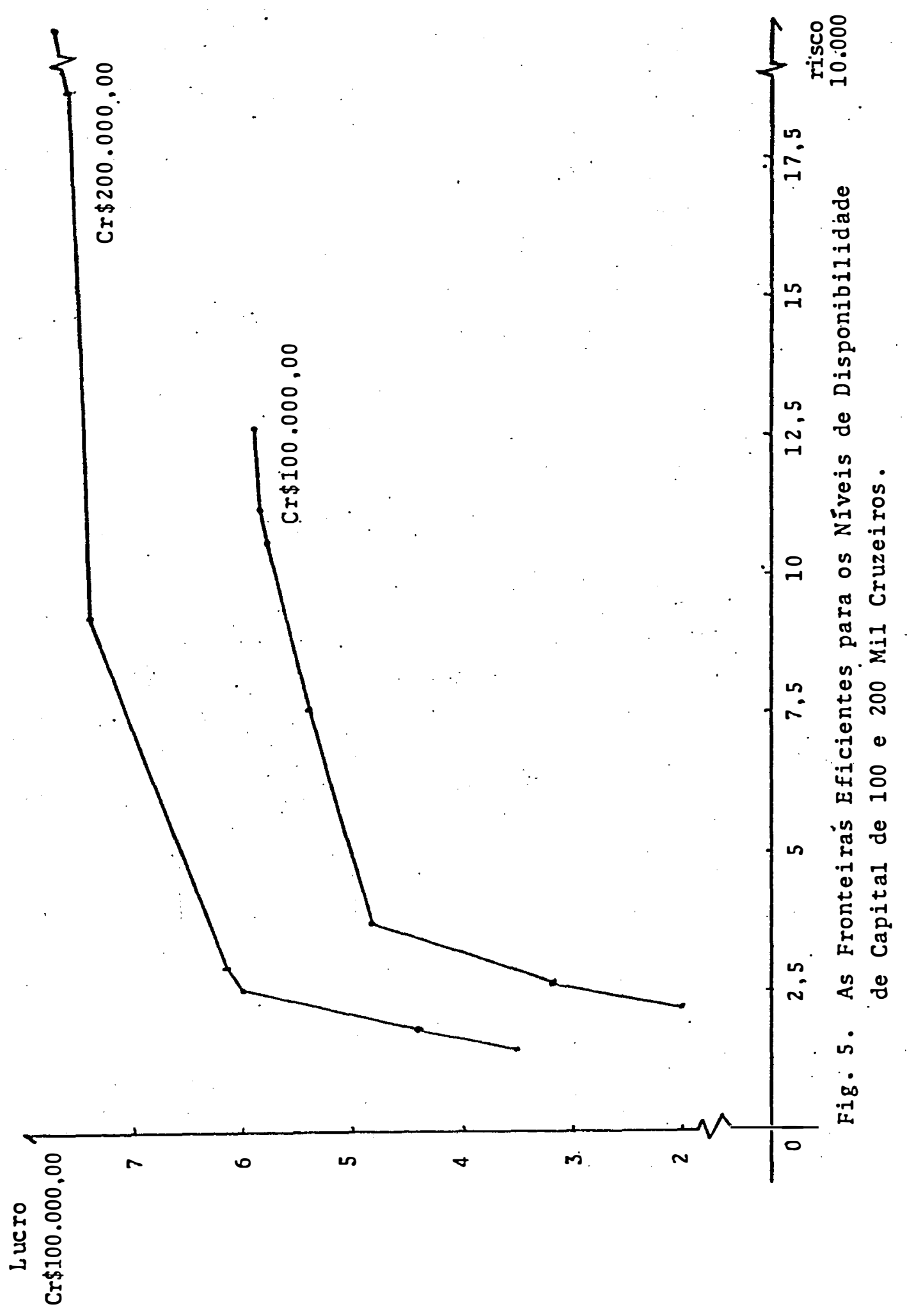




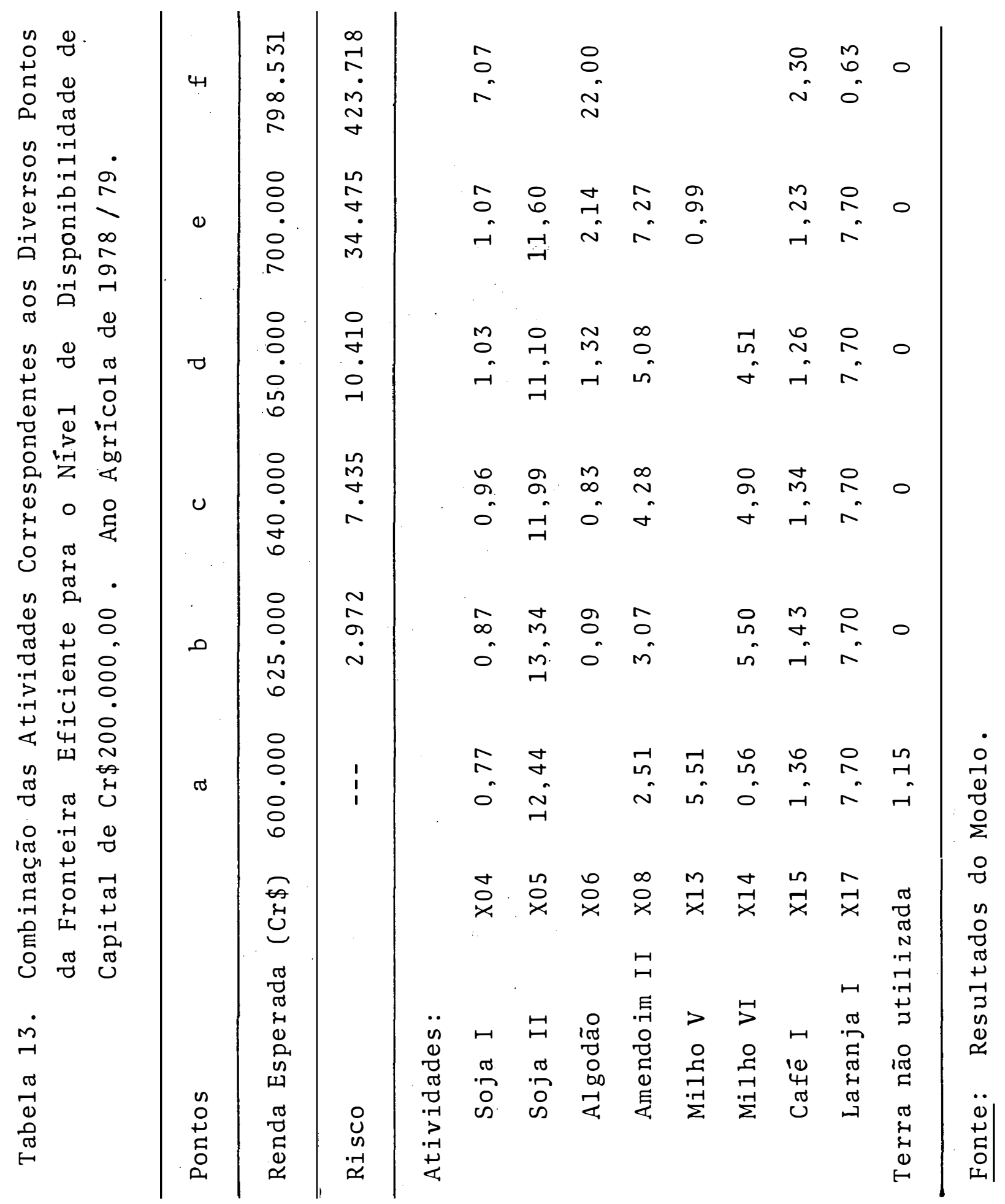




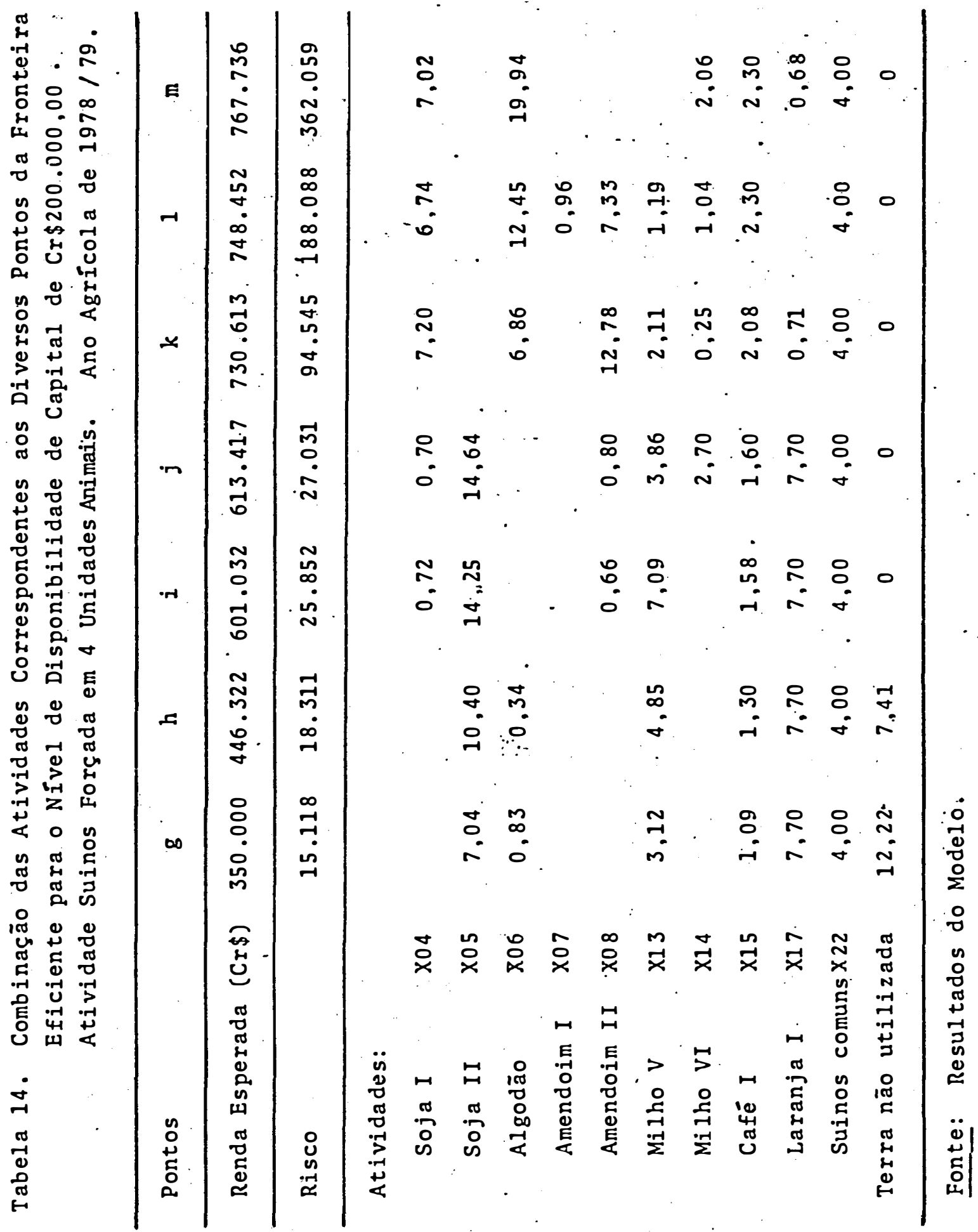


permitiu-se a revenda de milho comprado. Praticamente, só o milho de alta produtividade (140 sc/alq.) aparece nos pontos relevantes desta fronteira (pontos b, c, d). Nos demais seg mentos da fronteira eficiente, pontos e e $f$, a taxa de substituição lucro / risco decresce rapidamente, tornando-os pouco in teressantes para indivíduos aversos a risco. Como as tecnolo gias de milho de baixa produtividade (80 sc/alq.) não apareceram nestas soluções, decidiu-se forçar a atividade de produção de suínos no nível mínimo de 4 unidades animais (unidades porca), e também eliminar a possibilidade de revenda de milho. A tabela 14 mostra a composição de alguns pontos da fronteira eficiente correspondente. Como pode ser visto, o agricultor mais averso a risco procura se fixar nas culturas de soja de mais alta produtividade $(85 \mathrm{sc/alq} \cdot)$, um pouco de algodão, na manutenção de café e laranja e, na produção de milho de 120 sc por alqueire. Esta ärea (milho com produtividade intermediāria) cresce inicialmente e, à medida que se permite maior risco, ela decresce até desaparecer na solução de máximo lucro. 0 milho de alta produtividade (X14 com $140 \mathrm{sc} / \mathrm{alq}$. ) entra a partir de un certo nível de risco e de lucro, mantendo-se nas soluções finais (de retornos e risco relativamente altos) até na ūltima solução, que coincide com a de maximização de lucro da programação linear determinista. Isto sugere a rejeição da hipótese de que os agricultores cultivam milho de baixa produtividade como uma maneira de reduzir risco. 
As tabelas 13 e 14 mostram ainda alguns resulta dos interessantes. Primeiro, as culturas de arroz, bovinocul tura e suinocultura não aparecem (exceto quando forçados) em nenhum ponto das fronteiras eficientes. Quanto ao arroz, este resultado está de acordo com análises anteriores feitas para a região (PERES, 1971). Parece que modelos de otimização que incorporam risco usando o enfoque da Média-Variância não conseguem reproduzir, no que toca às culturas de subsistência, o comportamento dos agricultores da região. Sugere-se, por tanto, que estudos posteriores baseados neste enfoque, forcem a atividade no nível observado na propriedade típica. Este comportamento foi adotado no presente trabalho, para a suinocultura.

Uma das possíveis razões para o não aparecimento da atividade de produção de suínos nas soluções correspondentes a pontos da fronteira eficiente, está ligada às dificul dades de caracterização do nível tecnológico da suinocultura da região. Embora esta atividade seja praticada na região, com o fim principal de produção para o autoconsumo das empresas, pode-se notar a presença de certas características de tec nologias típicas de empreendimentos comerciais, tais como o uso de alguns animais de linhagens melhoradas (tipo carne, ao contrário do tradicional porco tipo banha) e eventuais constru ções de instalações de melhor nível de higiene. Como os dados disponíveis indicavam grandes variações tecnológicas, optou-se pelo uso, no modelo, de uma tecnologia típica de produ- 
ção de porco tipo banha, a qual era mais comum na amostra (moda). Os resultados estão indicando que a produção tradicional do porco tipo banha está perdendo (perdeu) sua competitiví dade com outras culturas. O fato da suinocultura local ter características tecnológicas de transição suporta esta hipótese.

Quanto à pecuária de corte, sua ausência nas so luções ótimas de agricultores aversos à risco pode dever-se à não incorporação da "dimensão" liquidez no presente enfoque de risco. Ativos fixos ou semi-fixos (da nomenclatura bancária) de alta liquidez (importante característica do capital empregado em bovinos) podem ser fundamentais como "hedging" contra eventos extremos dos quais o agricultor desconhece a função densidade (P.D.F.) .

A tabela 15 mostra as correlações entre as margens brutas (ou receitas brutas, jâ que foram admitidos custos constantes no período) das diversas atividades. A existência de valores negativos altos, em termos absolutos, propicia vantagens significantes à diversificação de atividades como forma de redução de risco. Assim, por exemplo, o aparecimento de plantio do amendoim na solução correspondente ao ponto $1 \mathrm{da}$ tabela 14, permite uma redução sensível no nível de risco, quando comparado ao ponto m (de 362.059 para 188.088) mantendo próximo do máximo o lucro esperado (de $\operatorname{Cr} \$ 767.736,00$ para ... Cr\$748.452,00). A tabela 15 mostra valores negativos para as correlações entre amendoim e as culturas de algodão, laranja, 


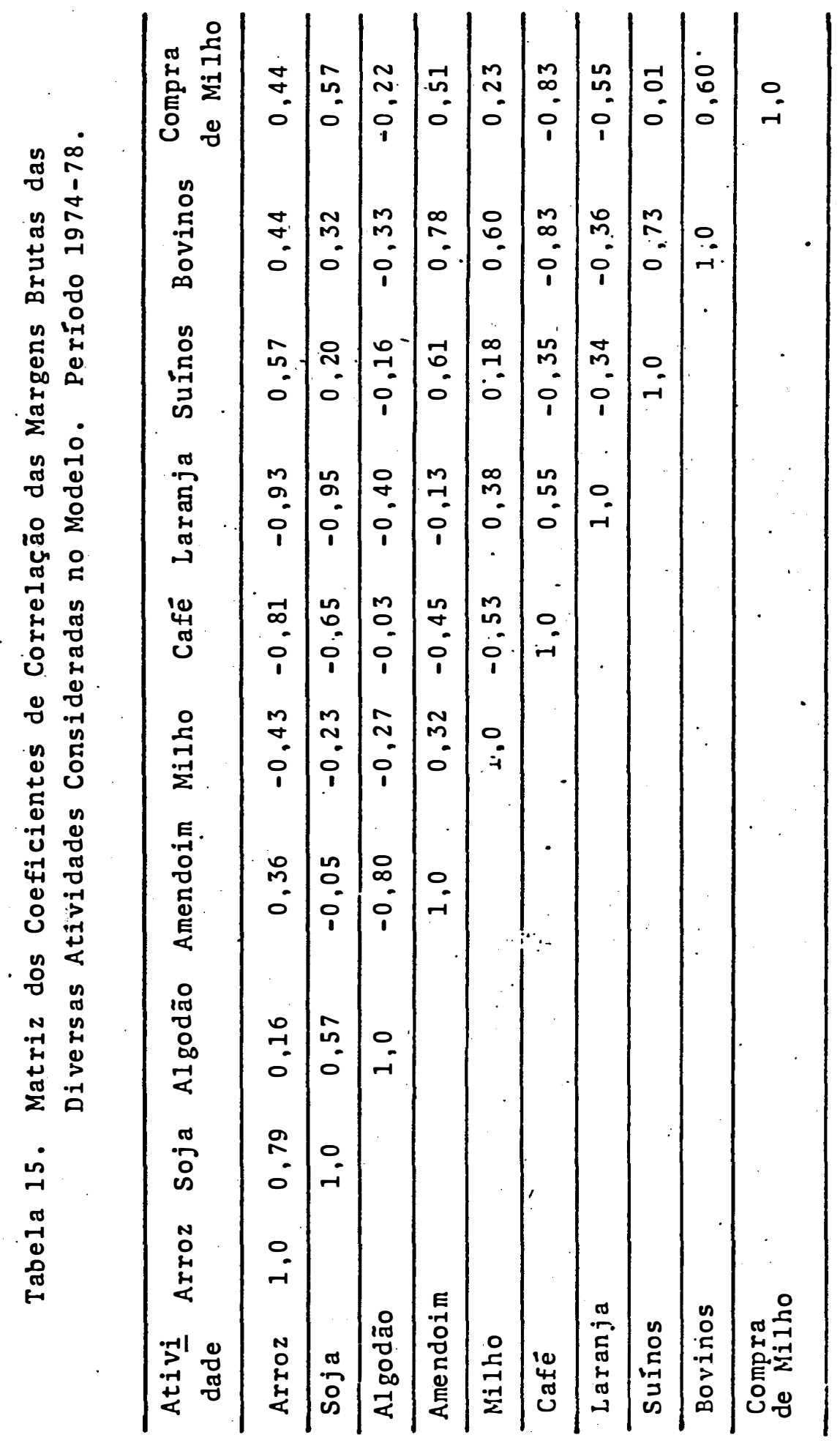


café e soja.

Importanites limitações do presente trabalho decorreram da impossibilidade de se determinar tecnologias alter nativas para produção de milho em terras de segunda (em geral as de baixa fertilidade) e em épocas diferentes de cultivo (timing). Uma outra possibilidade é de que a separação dos solos em duas categorias, como feita neste estudo, seja insuf $\underline{i}$ ciente para captar diferenças de respostas à adubação destes so 1os.

Quanto à aderença dos resultados do modelo à realidade encontrada com a pesquisa, pode-se dizer que a intro dução de risco melhorou sensivelmente a perfórmance da programação linear. Os dados da tabela 13 mostram que a baixos níveis de risco a combinação ótima de culturas está muito mais próxima da realidade observada que a proporcionada pelos resul tados da simples maximização de 1 ucros.

\subsection{Conclusões e recomendações}

0 modelo desenvolvido não permitiu explicar a persistência de baixa produtividade da terra na cultura do mitho como uma forma racional de decisão do agricultor de reduzir riscos. Evidentemente, com o tipo de modelo utilizado - normativo - o poder deste teste resume-se à verificação empí rica de um caso. A repetição deste trabalho, com estimativas 
autônomas das tecnologias e correspondentes variâncias dos retornos das diversas culturas talvez pudesse explicar a persistência daquela baixa produtividade. Parece ainda que o enfoque da média-variância para estudo de risco em regiões de tran sição não é suficiente para explicar a produção de certas culturas de subsistência tais como arrozicultura e suinocultura, mesmo quando se admite que os agricultores tem deficiência de capital operacional, uma das hipóteses do trabalho.

Uma segunda recomendação é de que este mesmo tipo de anālise seja desenvolvido num modelo dinâmico que incorpore outras formas de redução de risco. Em modelos dinâmi cos pode-se analisar a possibilidade do agricultor fazer fren te a eventos não previsiveis, mediante o desinvestimento de ativos líquidos. 
AZEVEDO F̊, A.J.B.V. e F.C.PÉRES, 1981. Competitividade da Cultura da Soja em uma Empresa da Região de Campinas, SP (a ser publicado na P.A.B.), 18 .

FREUND, R.J., 1956. The Introduction of Risk into a Programming Mode1. Econometrica, 24:253-263.

FUNDAÇÃO GETÚLIO VARGAS, Conjuntura Econồmica, alguns números.

FUNDAÇÃO GETÚLIO VARGAS, 1978. Retrospecto, $2^{\circ}$ semestre de 1977. Agroanalysis.

HAYAMI, Y. e RUTTAN, V.W., 1971. Agricultural development: an international perspective. Londres, The John Hopkins, $367 \mathrm{p}$. 
HAZELL, P.B.R., 1971. A linear Alternative to Quadratic and Semivariance Programming for Farm Planning under Uncertainty. American Journal of Agricultural Economics, 53(1) :53-62.

HOMEM DE MELO, F.B., 1974. O Brasil e o Mercado Internacional de carne bovina, milho e soja. Agricultura em São Paulo, $21(3): 1-39$.

HOMEM DE MELO, F.B., 1977. Produtividade da terra: os casos de milho e algodão no Estado de São Paulo. Revista de Economia Rura1, $15(1): 109-157$.

HOMEM DE MELO, F.B., 1979. Agricultura de Exportação e o Problema da Produção de Alimentos. Estudos Econômicos, $\underline{9}$ (3): $101-122$

HOMEM DE MELO, F.B., 1970. A Agricultura nos Anos 80: Perspectivas e Conflitos entre Objetivos de Política. Estudos Econômicos, 10(2) : 57-101.

INSTITUTO DE ECONOMIA AGRİCOLA, Agricultura em São Paulo, Informações Econômicas, diversos números.

KOOPMANS, T.C., 1971. Activity Analysis of Production_E Allocation, New Haven: Yale University Press, 405 p. 
MANUAL DE CRÉDITO RURAL - BACEN .

$-$

MARKOWITZ, H.M., 1952. Portfolio selection. The Journal of Finance, $7(1): 77-91$.

MATTOS, Z.P. de B., 1979. The Effect of Free Trade Policy on Brazilian Agriculture. A Micro Approach. Ohio State University, $116 \mathrm{p}$. (Tese de Ph.D.) .

MENDONÇA DE BARROS, J.R. e D.H.GRAHAM, 1978. Agricultura Bra sileira e o Problema da Produção de Alimentos. Pesquisa e $\underline{\text { Planejamento Econômico, }}$ 8 (3) : 695-725.

MOLINA F̊, J.., 1976. Classificação e Caracterização Sócio-Eco nômica dos Agricultores. Revista de Economia Rural, 14 (1): $175-212$.

MOLINA F, J. e T.J.BURKE, 1981 . Percepção e Não-Adoção do "Stant" Técnico na Cultura do Milho. Revista de Economia $\underline{\text { Rural, }} \underline{19}$ (1):129-145.

MUTH, J.F., 1961. Rational Expectations and the Theory of Price Movements. Econometrica, 29 (July). 
NORONHA, J.F., 1981. Projetos Agropecuários: Administração Financeira, Orçamenta ção e Avaliação Econômica. Piracicaba, SP, FEALQ, 274 p.

PAIVA, R.M., 1968. O Mecanismo de Auto Controle no Processo de Expansão da Melhoria Técnica de Agricultura. Revista Brasileira de Economia, 22(3):5-38.

PAIVA, R.M., 1971. Modernização e Dualismo Tecnológico na Agricultura. Pesquisa e Planejamento Econômico, 1 (2):171-234 .

PASTORE, J.; G.L.S.DIAS e M.C. de Castro, 1976. Condicionantes da Produtividade da Pesquisa Agrícola no Brasil. Estudos Econômicos, $\underline{6}$ (3):147-182.

PÉRES, F.C., 1976. Derived Demand for Credit under Conditions of Risk. Ohio State University, $141 \mathrm{p}$. (Tese de Ph.D.) .

PÉRES, F.C., 1979. O Pequeno Produtor e o Abastecimento do Mercado Interno de Gêneros Alimentícios. Revista de Econo$\underline{\text { mia Rural, }} \underline{17}(3): 79-83$.

PINAZZA, L.A.; ENGLER, J.J.C. e PÉRES, F.C., 1979. Demanda por Crédito na Divisão Regional Agrícola de Campinas. Re-

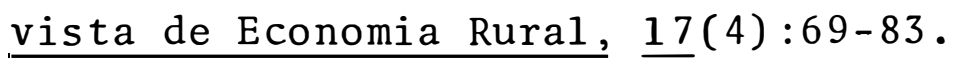


SÃO PAULO, Secretaria da Agricultura. Instituto de Economia Agrícola, 1972. Desenvolvimento da Agricultura Paulista, $319 \mathrm{p}$.

SEVER, F.A. de A. e A. de A.VEIGA F, 1977. Uma Contribuição ao Estudo de Resposta de Ārea aos Estímulos de Preços de Amendoim, Arroz, Feijão, Milho e Soja no Estado de São Pau10. Revista de Economia Rural, 15(1):45-92.

SCHUH, G.E., 1974. The Current State of Economic Theory for the Explanation of Subsistence Agriculture. Seminário de Pesquisa em Alternativas de Desenvolvimento para Grupos de Baixa Renda na Agricultura Brasileira. Piracicaba, ESALQ/ /USP (mimeografado), $45 \mathrm{p}$.

THOMPSON, R.L. e G.E.SCHUH, 1978. Política Comercial e Exportação: o Caso do Milho no Brasil. Pesquisa e Planejamento Econômico, $\underline{8}(3): 663-693$.

TOBIN, J., 1958. Liquidity Preference as Behavior Towards Risk. Rev. Econ. Studies, 25:65-86. 


\section{APÊNDICE A}

Matriz dos Coeficientes Técnicos,

Preços. e Restrições 


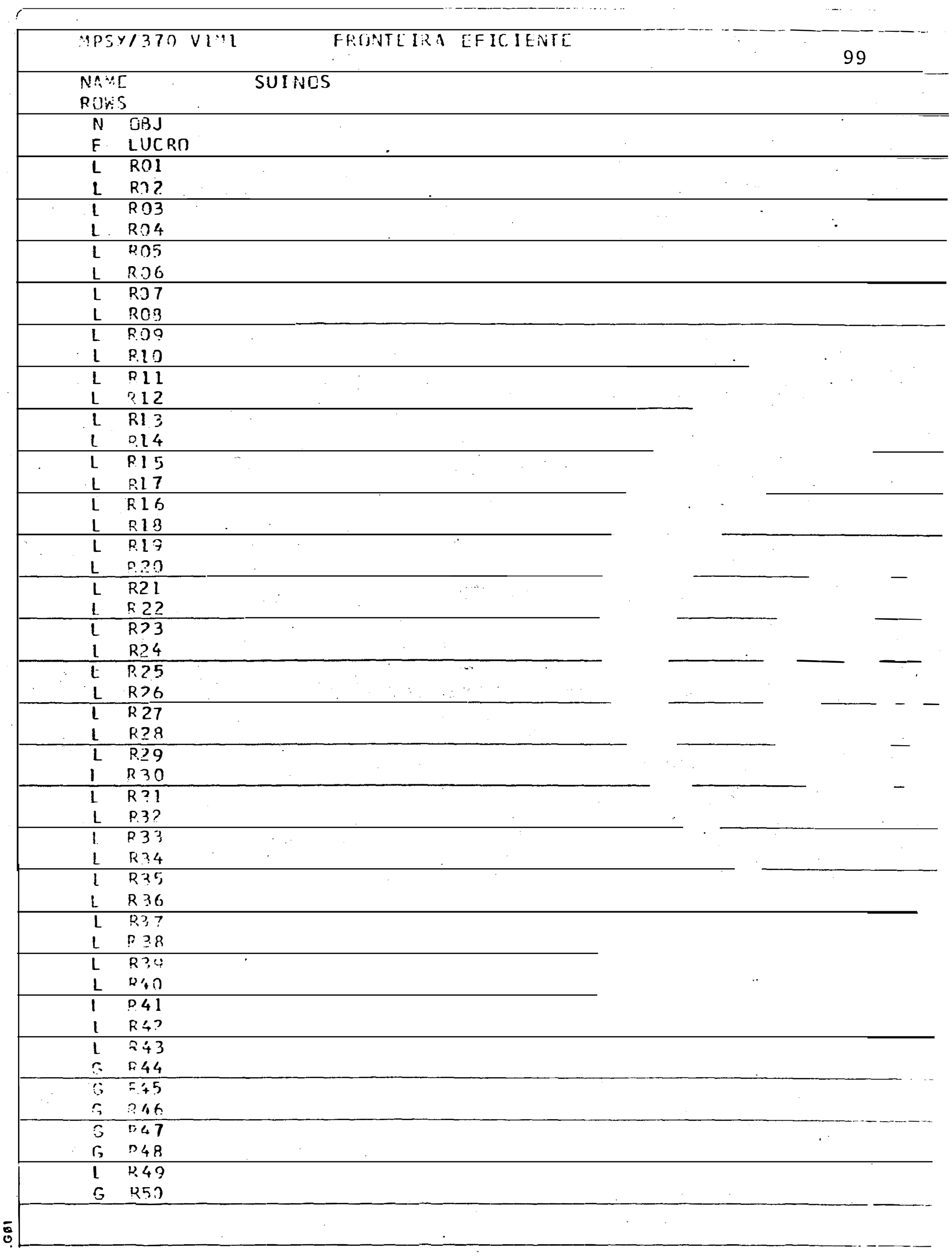




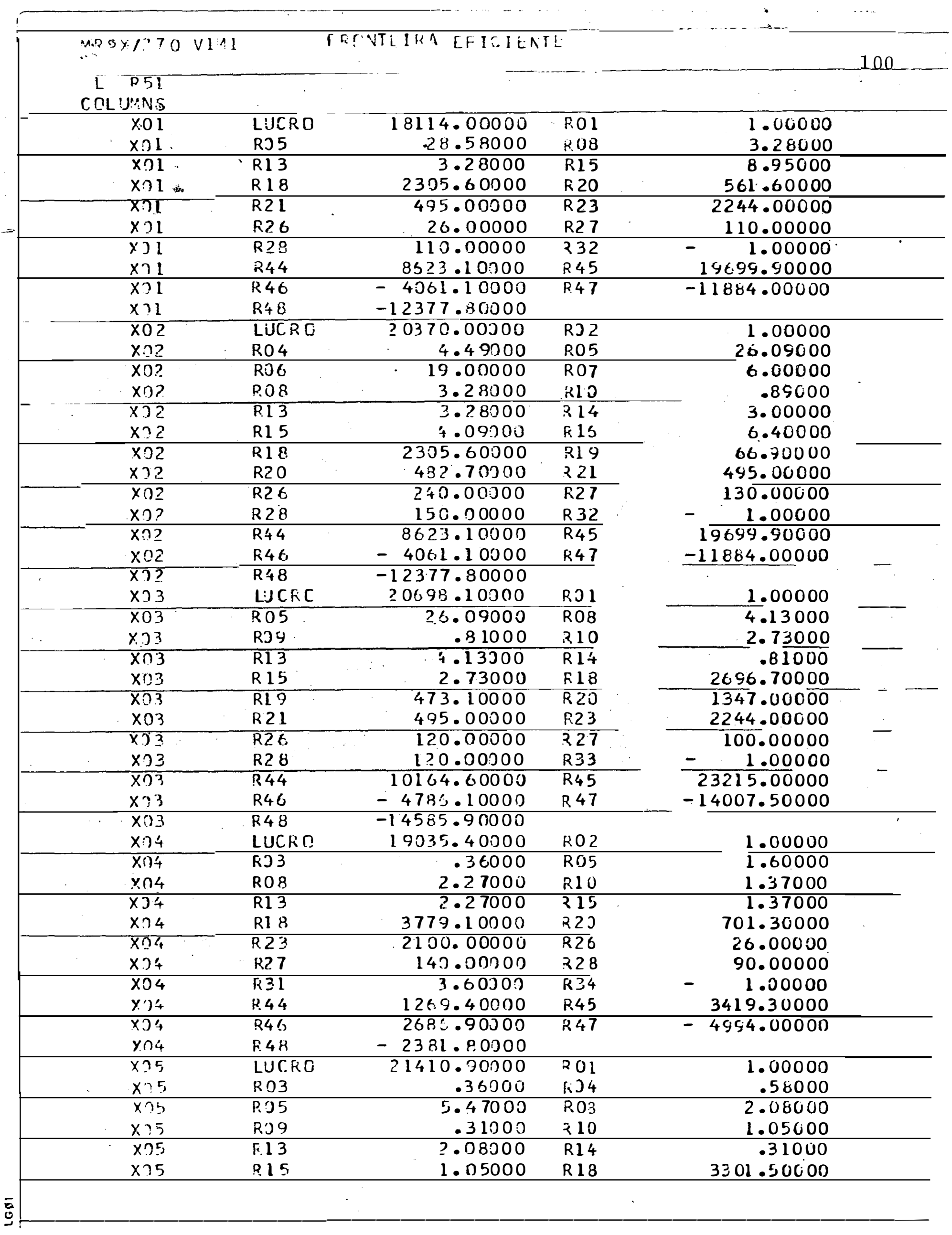




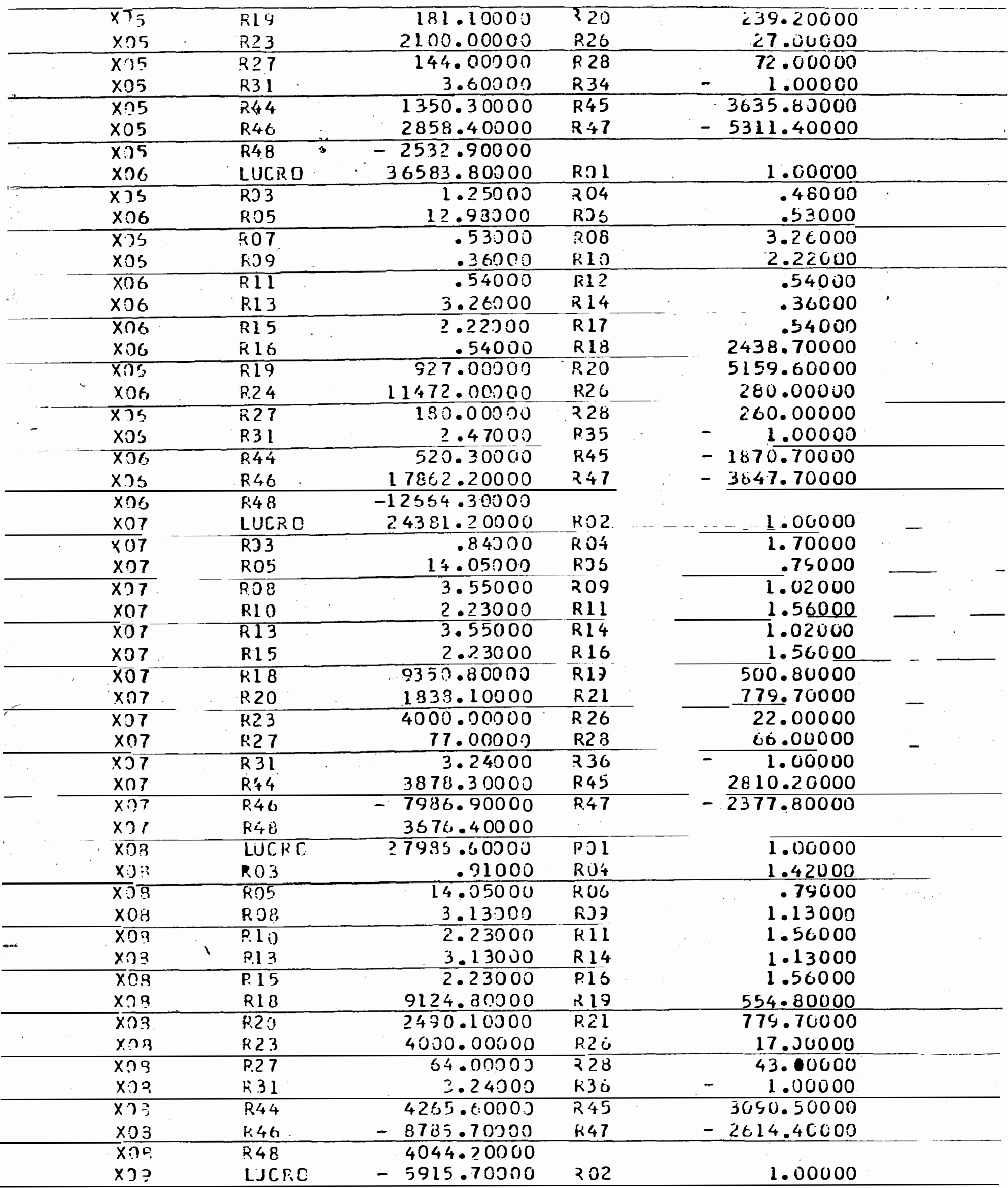




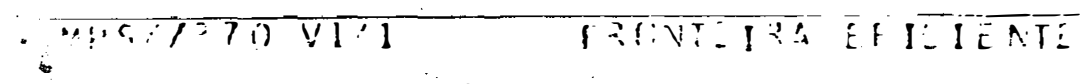

102

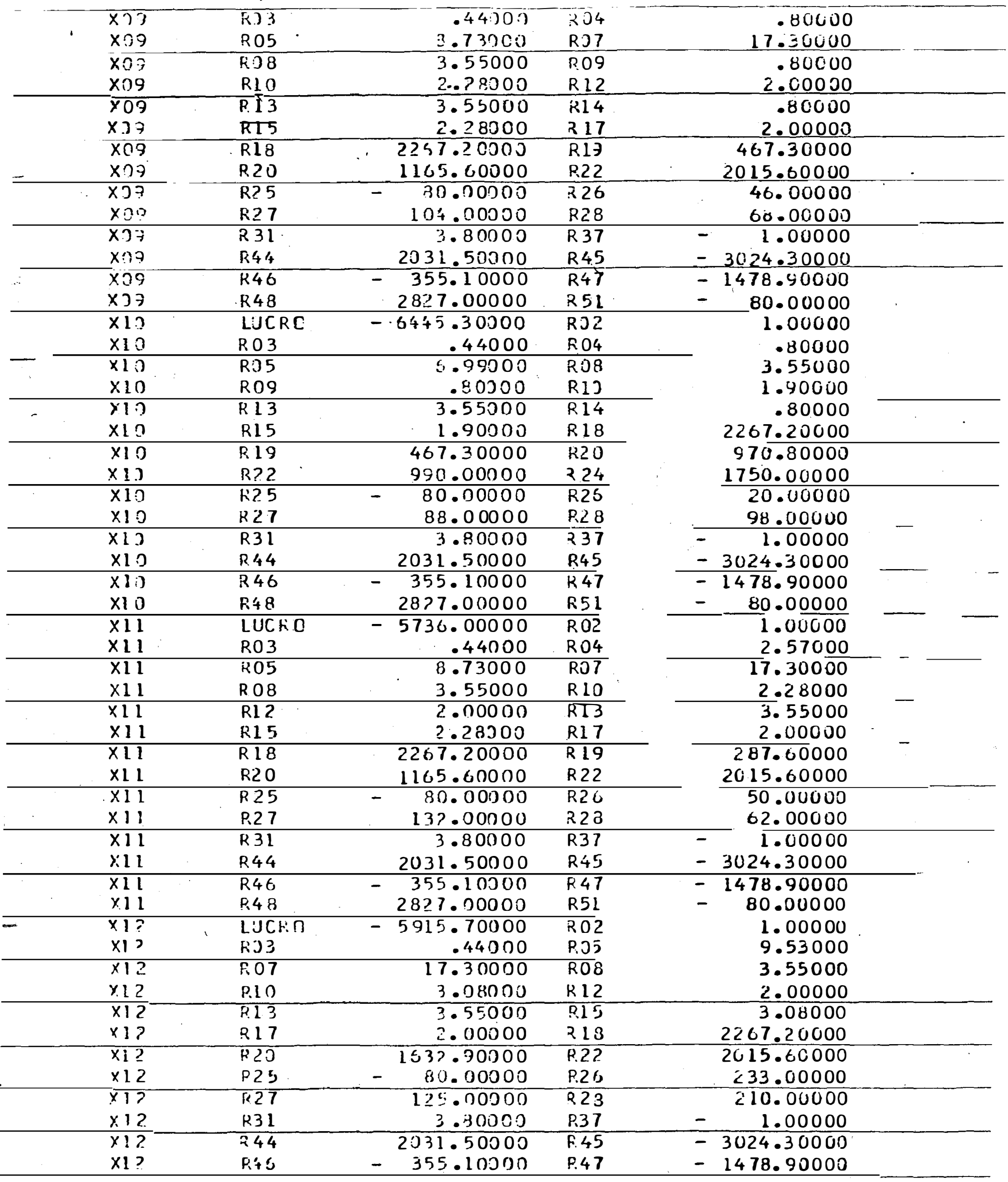




\begin{tabular}{|c|c|c|c|c|c|c|}
\hline & $\begin{array}{l}\times 12 \\
\times 13\end{array}$ & $\begin{array}{l}R+8 \\
L U C \div C\end{array}$ & $\begin{array}{r}28 ? 7.100000 \\
-\quad 5517.40000 \\
\end{array}$ & $\begin{array}{l}\text { P.51 } \\
\text { FiOl }\end{array}$ & $\begin{array}{r}80.00000 \\
1.00000\end{array}$ & \\
\hline & $\times 13$ & $R 03$ & .51000 & $\therefore 05$ & 7.78000 & \\
\hline & $\times 13$ & RO 7 & 16.30000 & R03 & 2.56000 & \\
\hline & $X[3$ & RIO & .2 .69000 & $\mathrm{Rl} 2$ & 2.00000 & \\
\hline & $\times 13$ & $\mathrm{R} 13$ & 2.56000 & $R 15$ & 2.69000 & \\
\hline & $\times 13$ & RL 7 & $? .00000$ & RI 8 & 1816.60000 & \\
\hline & $\times 13$ & $R 20$ & 1432.20000 & R 22 & 2268.60000 & \\
\hline & $x 13$ & R?5 & -123.00000 & R2S & 22.00000 & \\
\hline & $\times 13$ & $\mathrm{R} 27$ & 157.00000 & $\mathrm{R} 28$ & 83.00000 & \\
\hline & $\times \sqrt{3}$ & R31 & 3.60000 & $\pi 38$ & 1.00000 & \\
\hline & $\times 13$ & R't4 & $30 ; 7.00000$ & $R 45$ & -452.0 .80000 & \\
\hline & $x ; 3$ & 846 & -531.40000 & $R+7$ & -2210.50000 & \\
\hline$\cdot$ & $\times 13$ & $R 48$ & $42 ? 5.30000$ & R 51 & $-\quad 120.00000$ & \\
\hline & $\times 14$ & LUCPE & -5935.50000 & RJ I & 1.00000 & \\
\hline & $\times 14$ & $\mathrm{RO} 3$ & .51000 & Ro't & .79000 & \\
\hline & $\times 1 \cdot 4$ & Fo5 & 8.19000 & $\mathrm{RO3}$ & 2.56000 & \\
\hline & $x ! 4$ & ROO & .79000 & RIJ & 2.28000 & \\
\hline - & $\overline{\times 14}$ & $\overline{R 13}$ & 2.56000 & 214 & .79000 & \\
\hline- & $\times 14$ & R.15 & $? . ? 8000$ & $\mathrm{R} 13$ & 1816.00000 & \\
\hline & $\times 14$ & R19 & 461.40000 & R2O & $1 1 6 5 \longdiv { . 6 0 0 0 0 }$ & \\
\hline & $\times 14$ & P.28 & 1243.00000 & 223 & 2300.00000 & \\
\hline & $x \overline{14}$ & $R 25$ & $-1+0.00300$ & R25 & 180.00000 & \\
\hline & $x 14$ & R2 27 & $\quad 120.00000$ & $R 23$ & 150.60000 & - \\
\hline & $\times 1 \%$ & R3I & 3.60000 & R39 & 1.00000 & - \\
\hline & $\times 14$ & 844 & 3795.90000 & $R 45$ & -5650.70000 & \\
\hline & $\times 14$ & $\mathrm{R} 46$ & -653.30000 & 247 & -2762.90000 & \\
\hline & $\times 14$ & $R 48$ & 5231.40000 & R.51 & $-\quad 140.00000$ & \\
\hline & $\bar{x} \overline{5}$ & LUCRC & 69980.40000 & RO? & $1.0 \overline{0000}$ & \\
\hline & $\times 15$ & $\mathrm{RO} 3$ & 74.00000 & $\mathrm{RO} 04$ & $21 \cdot 00000$ & - \\
\hline & $\times 15$ & $\overline{R 05}$ & 30.00000 & RJS & 18.00000 & - \\
\hline & $\times 15$ & $K 07$ & 57.60000 & Ros & 2.63000 & - \\
\hline & $\times 15$ & RO9 & 1.50300 & R.10 & 3.23000 & - \\
\hline & $\times 15$ & $\mathrm{R} 12$ & .00000 & R13 & 2.63000 & - \\
\hline & $x ! 5$ & $\mathrm{R} 14$ & 1.50000 & 215 & 3.23000 & - \\
\hline- & $\times 15$ & $\mathrm{R} 17$ & .90000 & R.LB & 3020.20000 & \\
\hline & $\times 15$ & $2: 13$ & 66.90000 & $R 20$ & 1375.00000 & \\
\hline & $\times 15$ & R.2.2 & 366.30000 & 226 & 260.00000 & \\
\hline & $\times 15$ & : 27 & 90.00000 & $R 2 B$ & 200.00000 & \\
\hline & $\times 15$ & R.40 & 1.00000 & $2+2$ & 1.00000 & \\
\hline & $\times \overline{15}$ & R44 & $-299 ? 8.50000$ & $\overline{R 45}$ & -7339.30000 & \\
\hline & $\times 15$ & $R 4 \dot{C}$ & $-\quad 3484.90000$ & 847 & 60151.20000 & \\
\hline - & $\times 15$ & $\overline{R 48}$ & -19299.40300 & & & \\
\hline- & $\times 16$ & LUCE: C & 25852.30000 & 8.02 & 1.00000 & \\
\hline & $\times 16$ & 203 & 4.30000 & 204 & 7.20000 & \\
\hline & $x 15$ & ROS & 132.70000 & ROE & 6.00000 & \\
\hline & $\times 16$ & R.37 & 8.40000 & $\mathrm{ROB}$ & 2.88000 & \\
\hline & $\times 15$ & $R \cap C_{j}$ & 1.20000 & $\therefore 10$ & 5.04000 & \\
\hline & $\times 16$ & $\mathrm{R} 12$ & .12300 & 213 & 2.88000 & \\
\hline & $\times 16$ & 214 & 1.20000 & $R 15$ & 5.04000 & \\
\hline & נ) & P17 & .12300 & 218 & 1501.00000 & \\
\hline & $\times 16$ & Pl ; & $534.4000 !$ & R2J & 12530.30000 & \\
\hline & $\times 15$ & 522 & 61.54300 & P.25 & 240.00000 & \\
\hline & $\times 15$ & 227 & 60.00000 & R23 & 240.00000 & \\
\hline
\end{tabular}




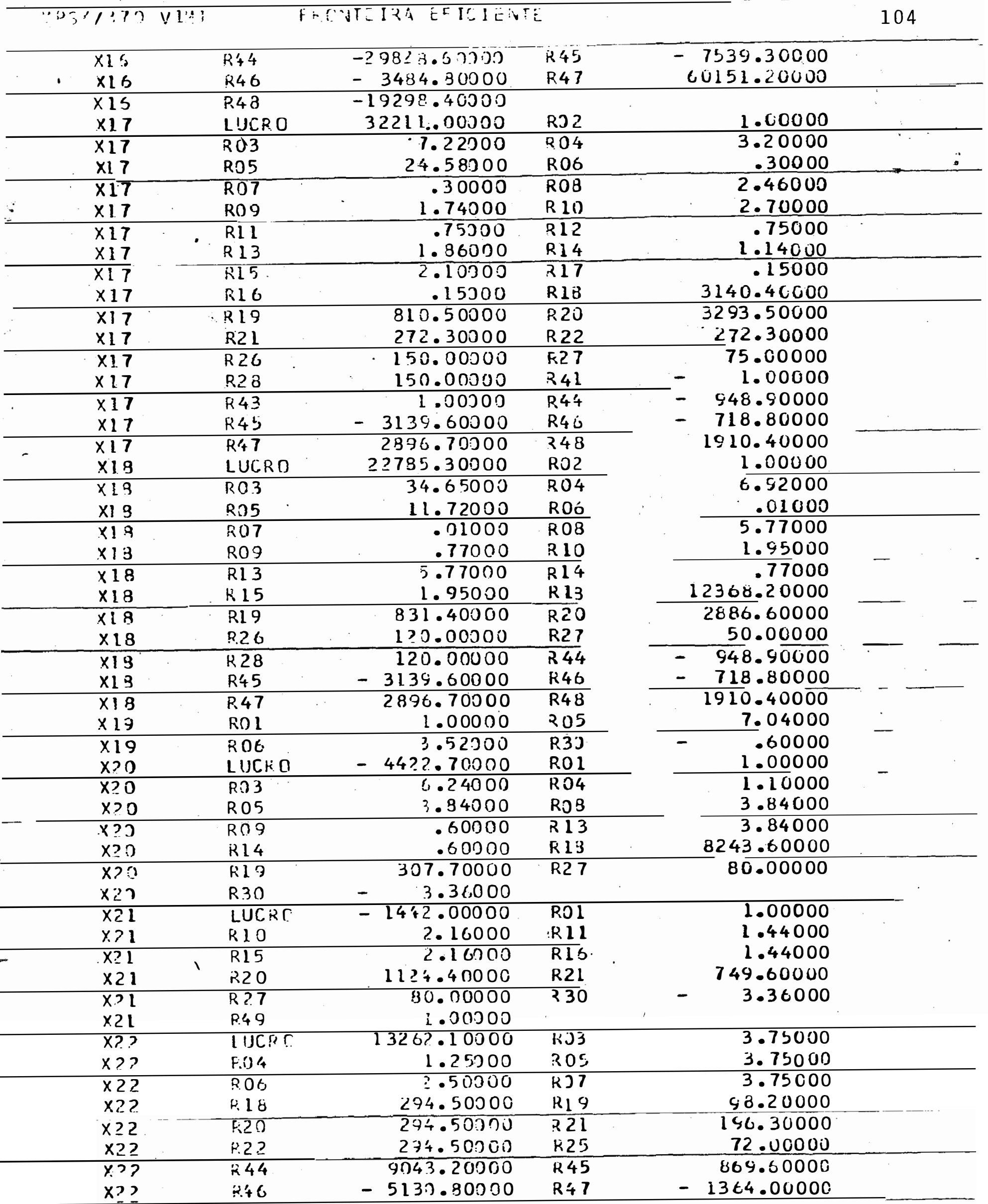




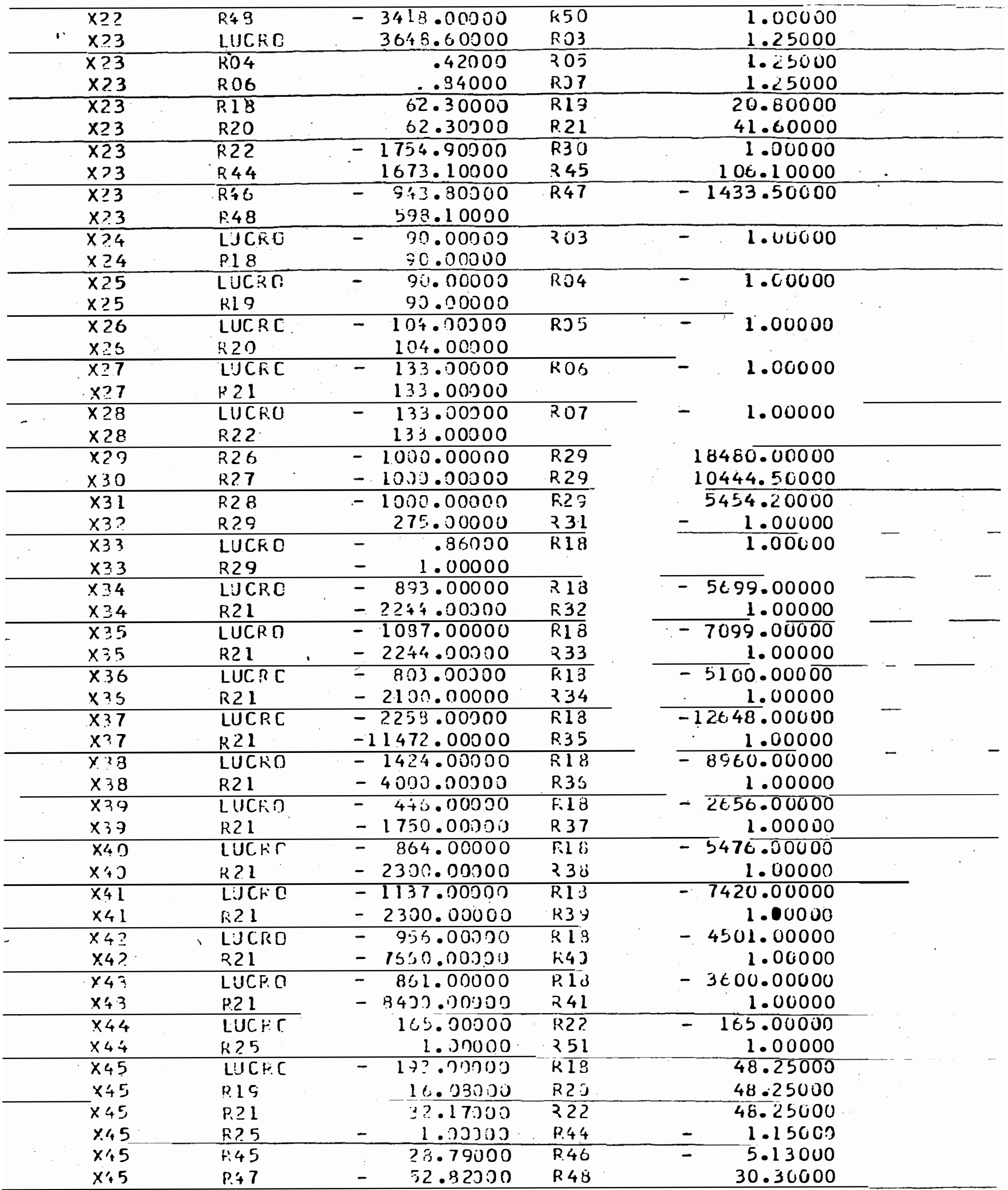




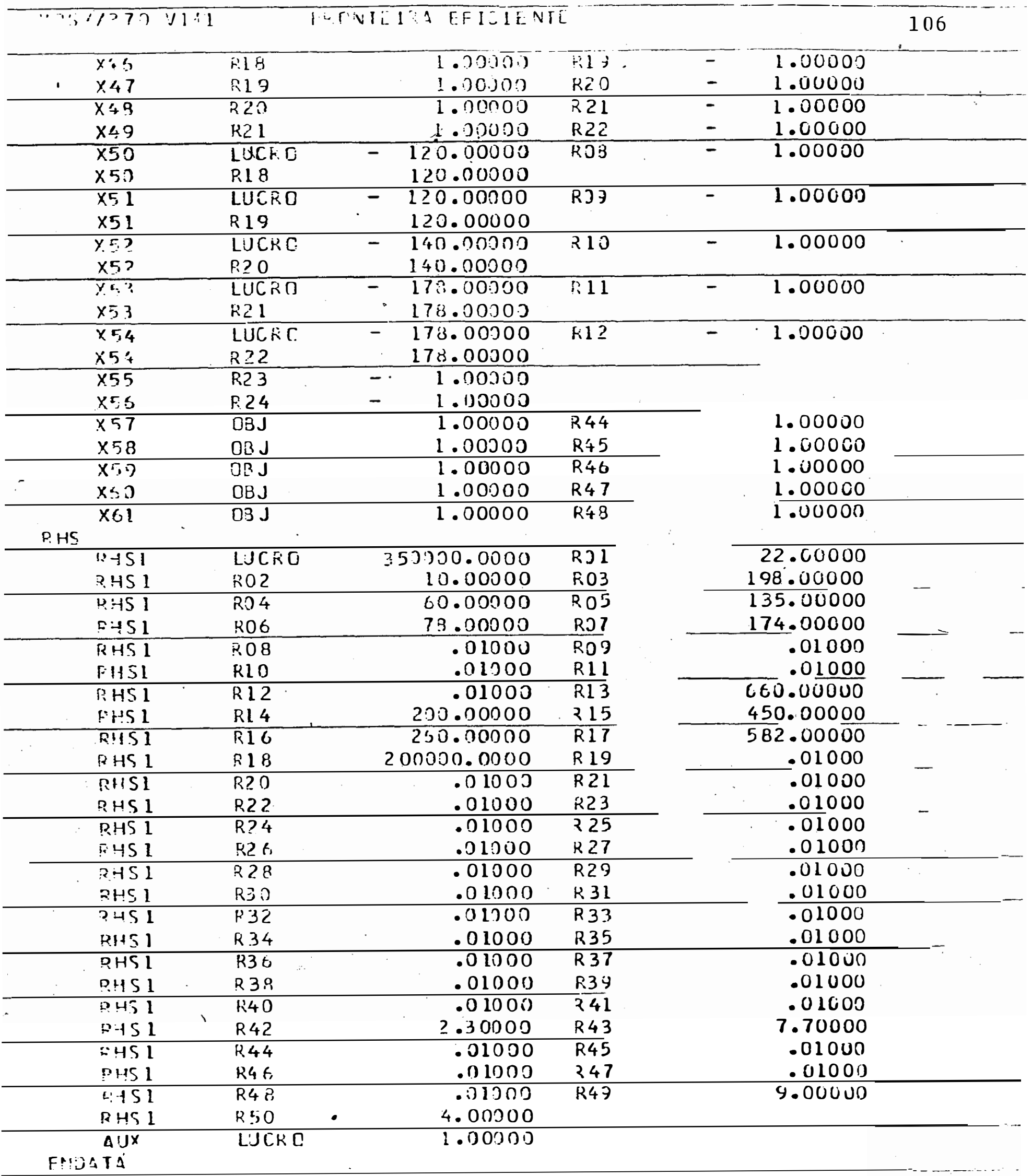




\title{
APÊNDICE B
}

\author{
Exigência de Fatores e Custo Operacional \\ na Formação do Cafezal
}




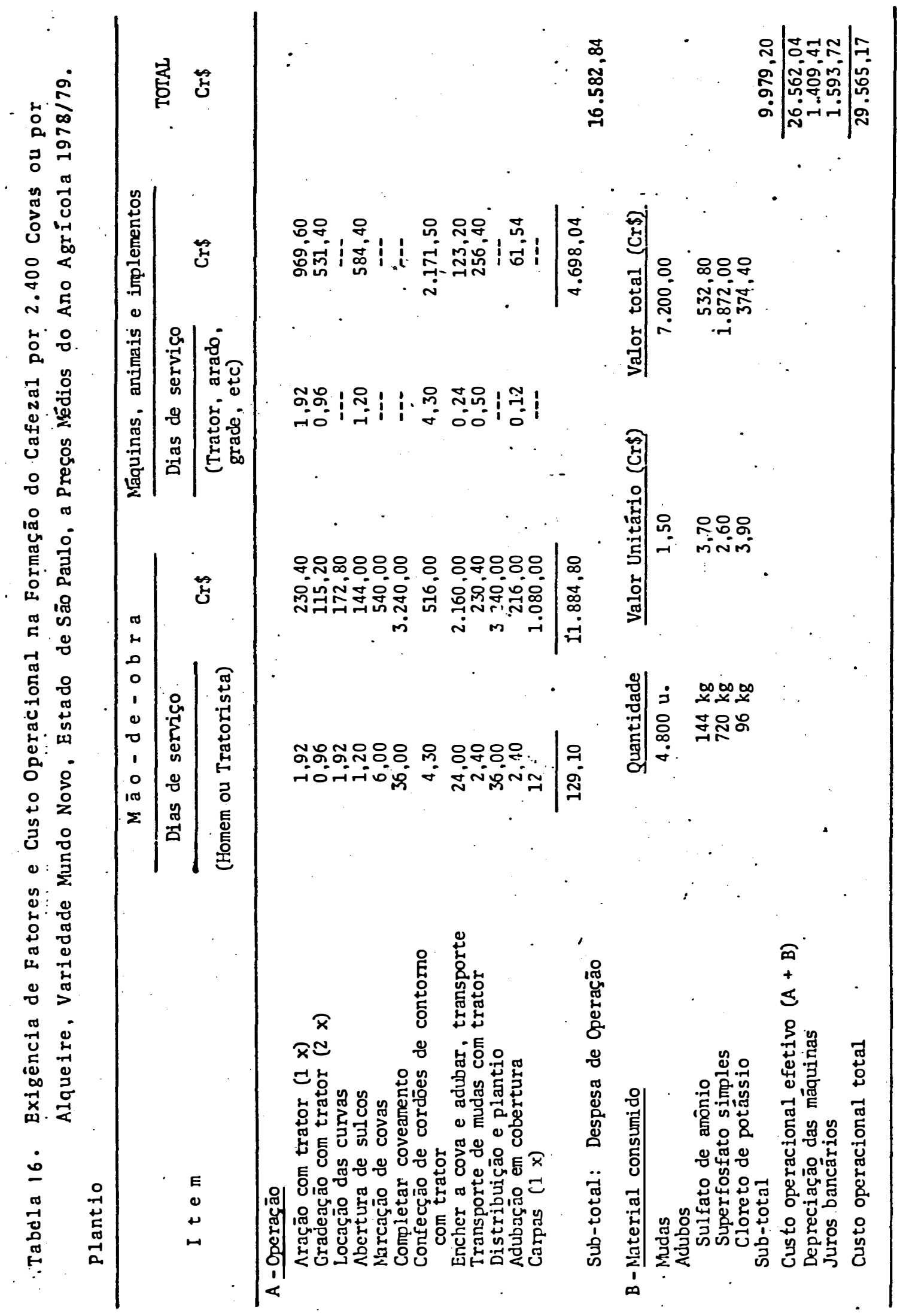




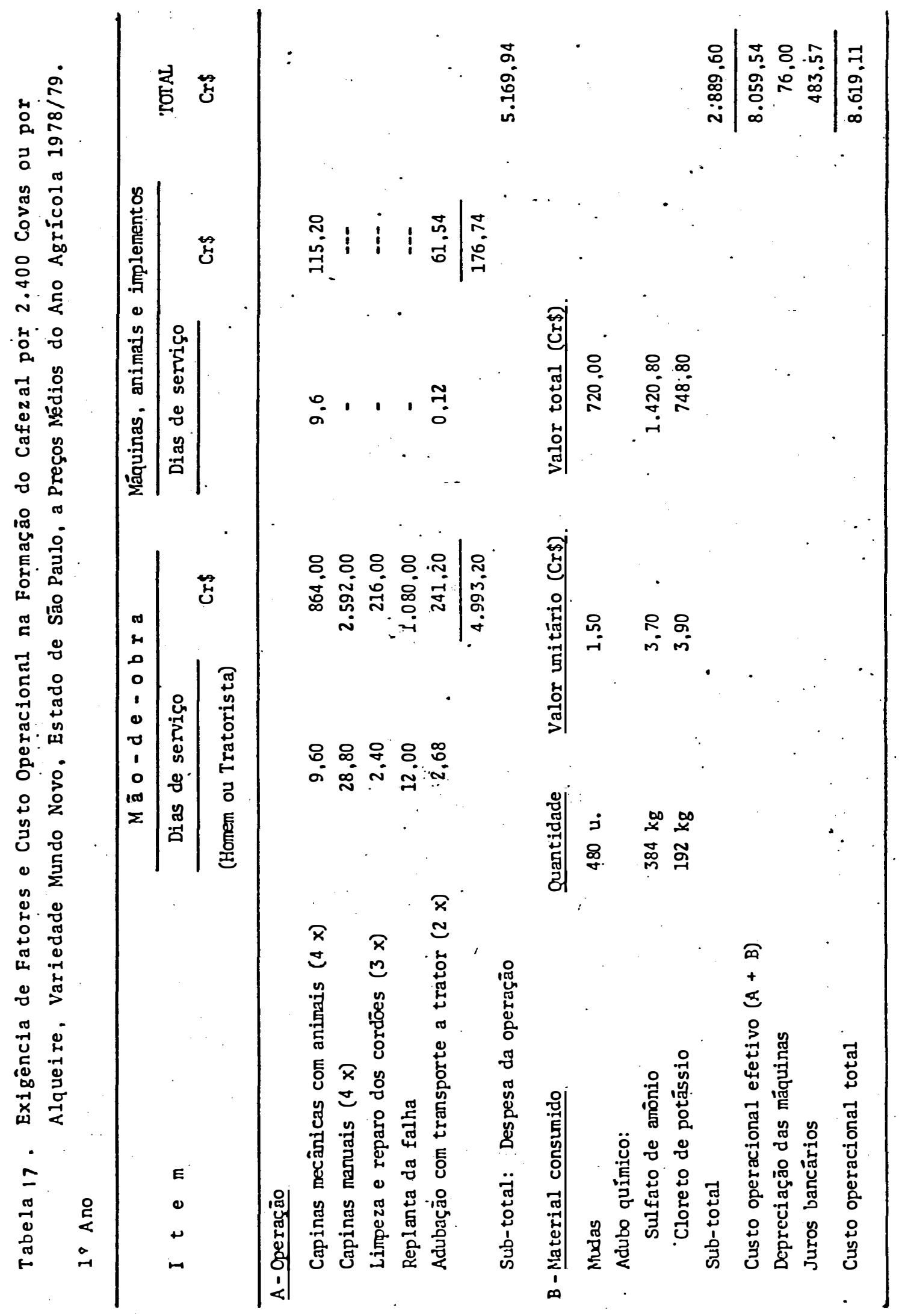




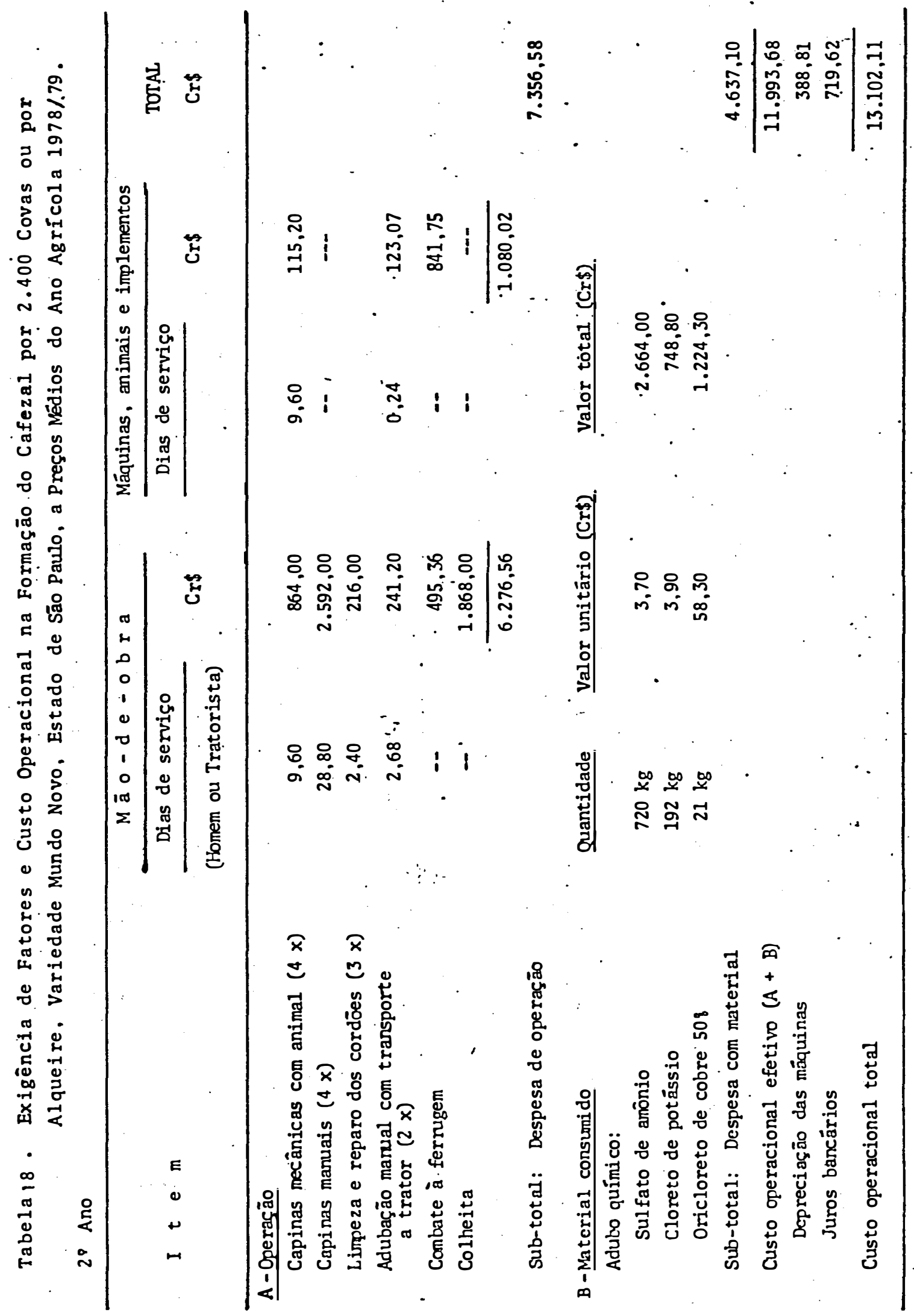




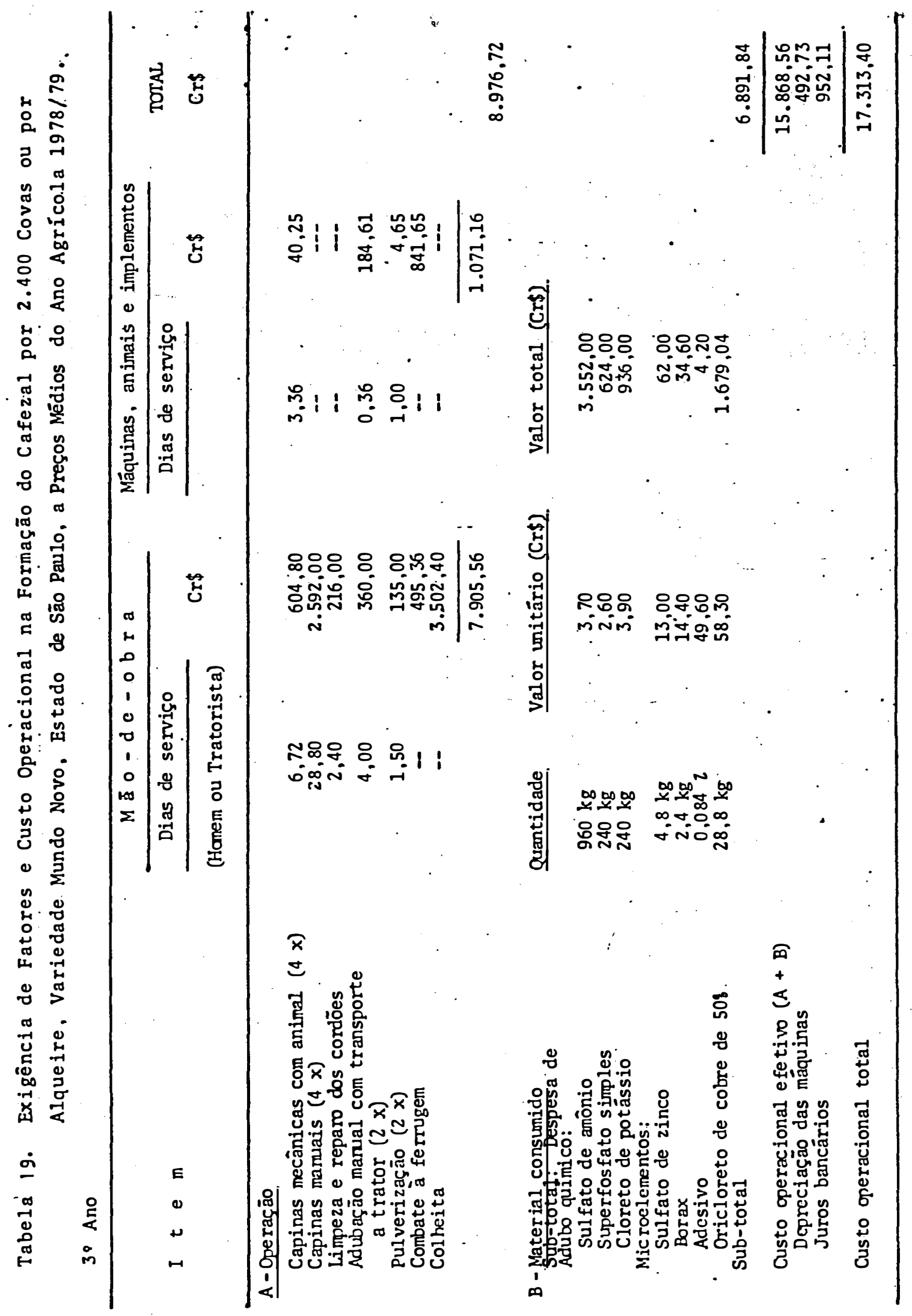




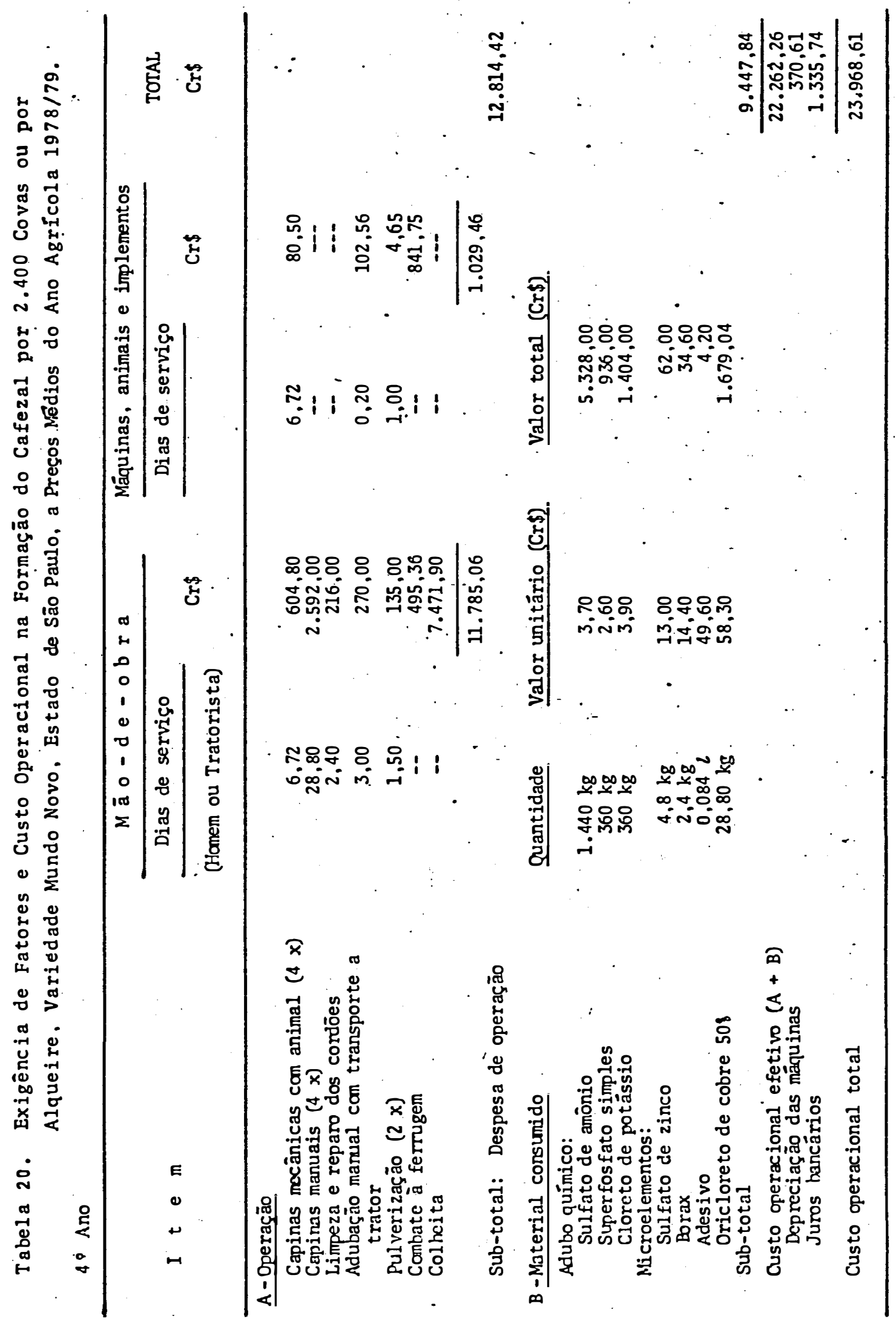




\section{APÊNDICE C}

Estimativa de Custo Operacional

e Exigência Física de Fatores na Formação da Cultura da Laranja 


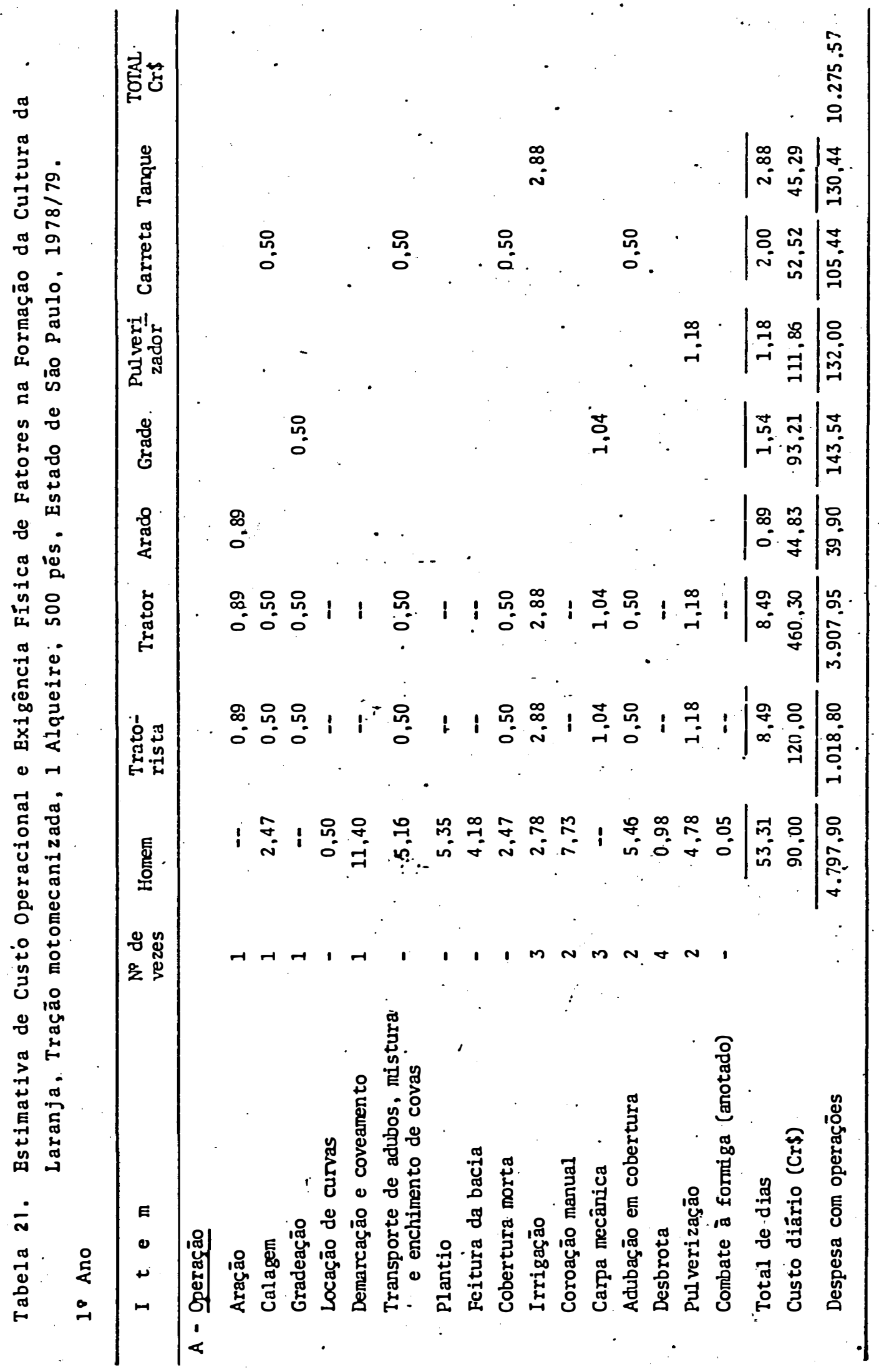




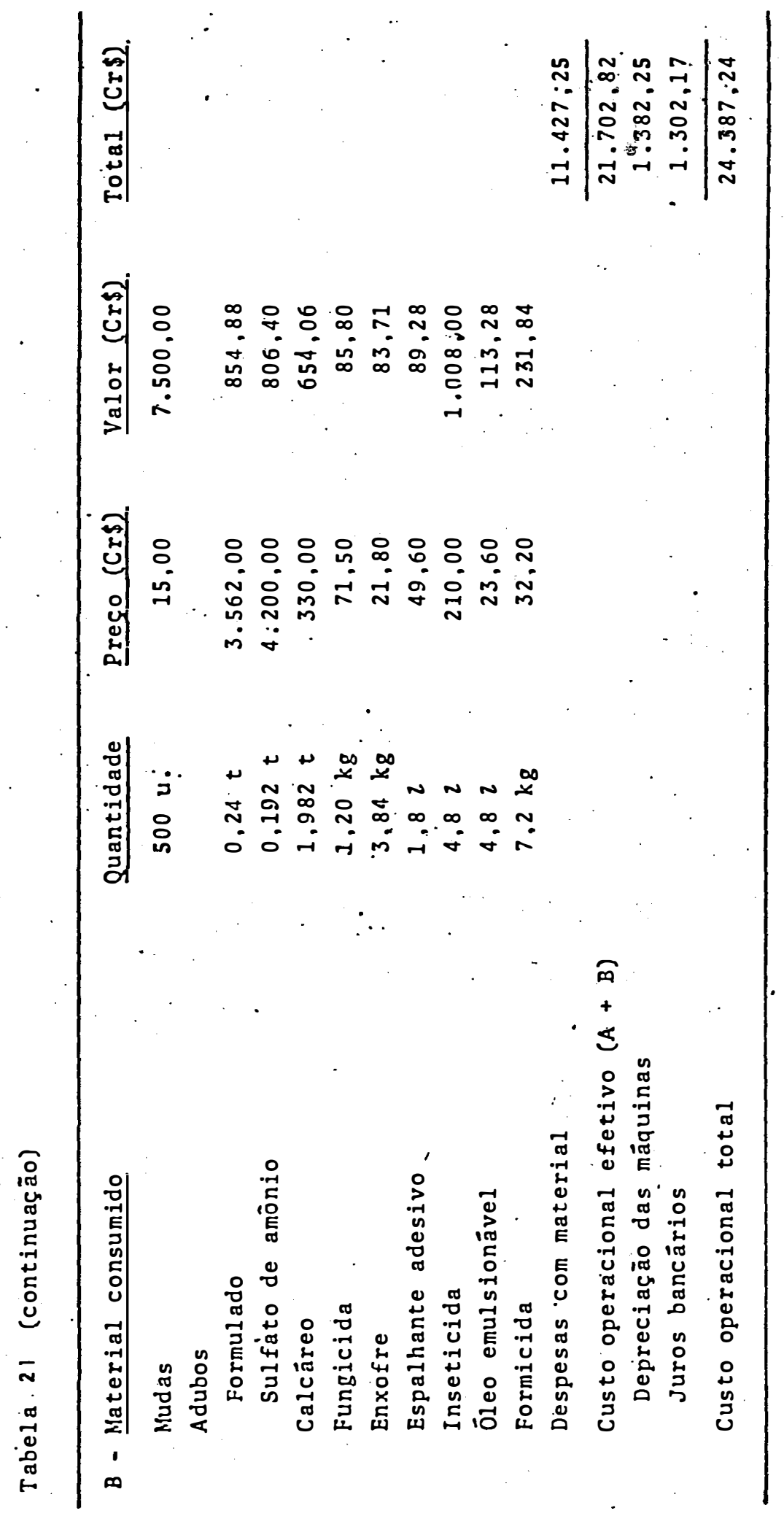




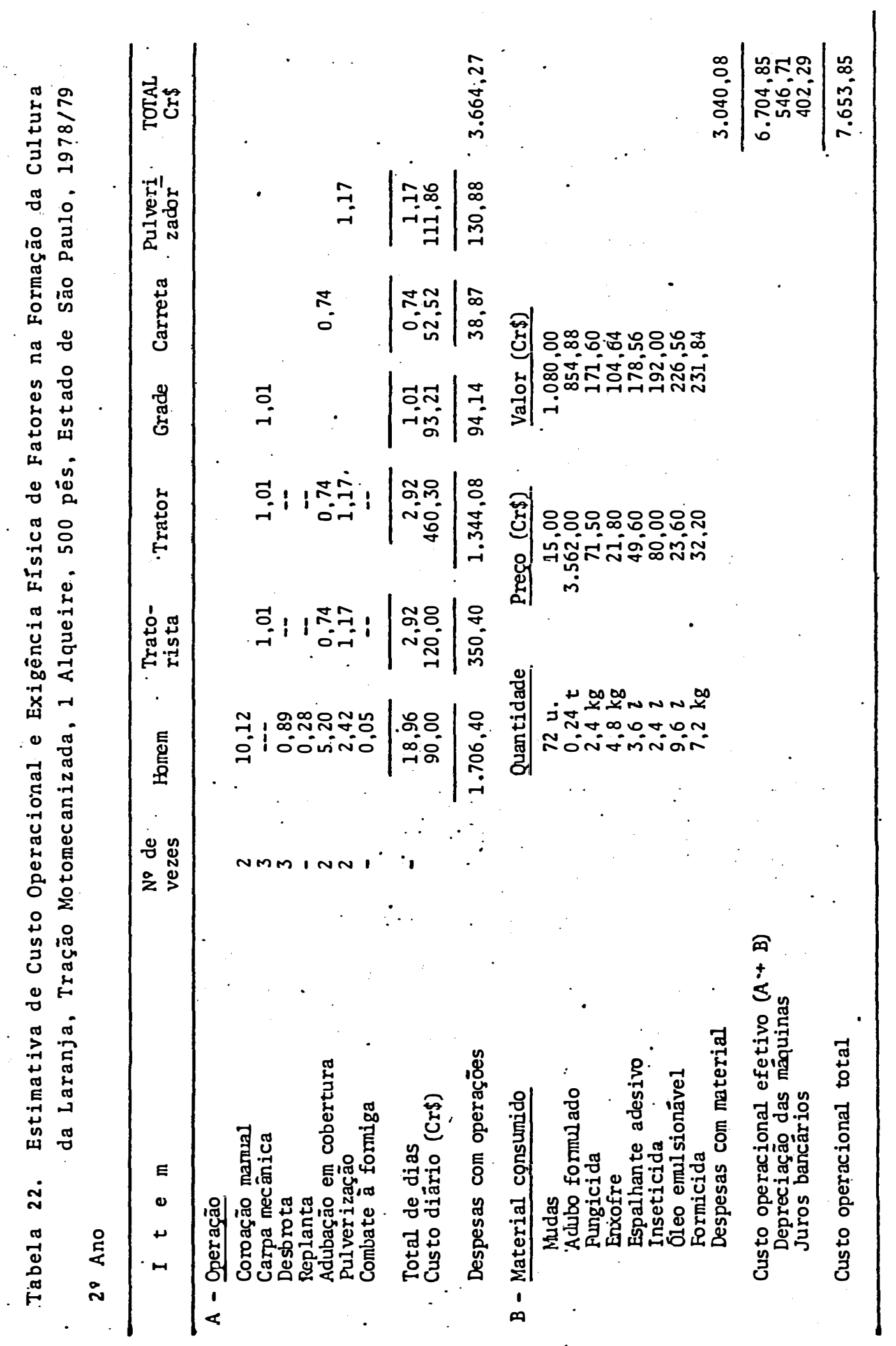




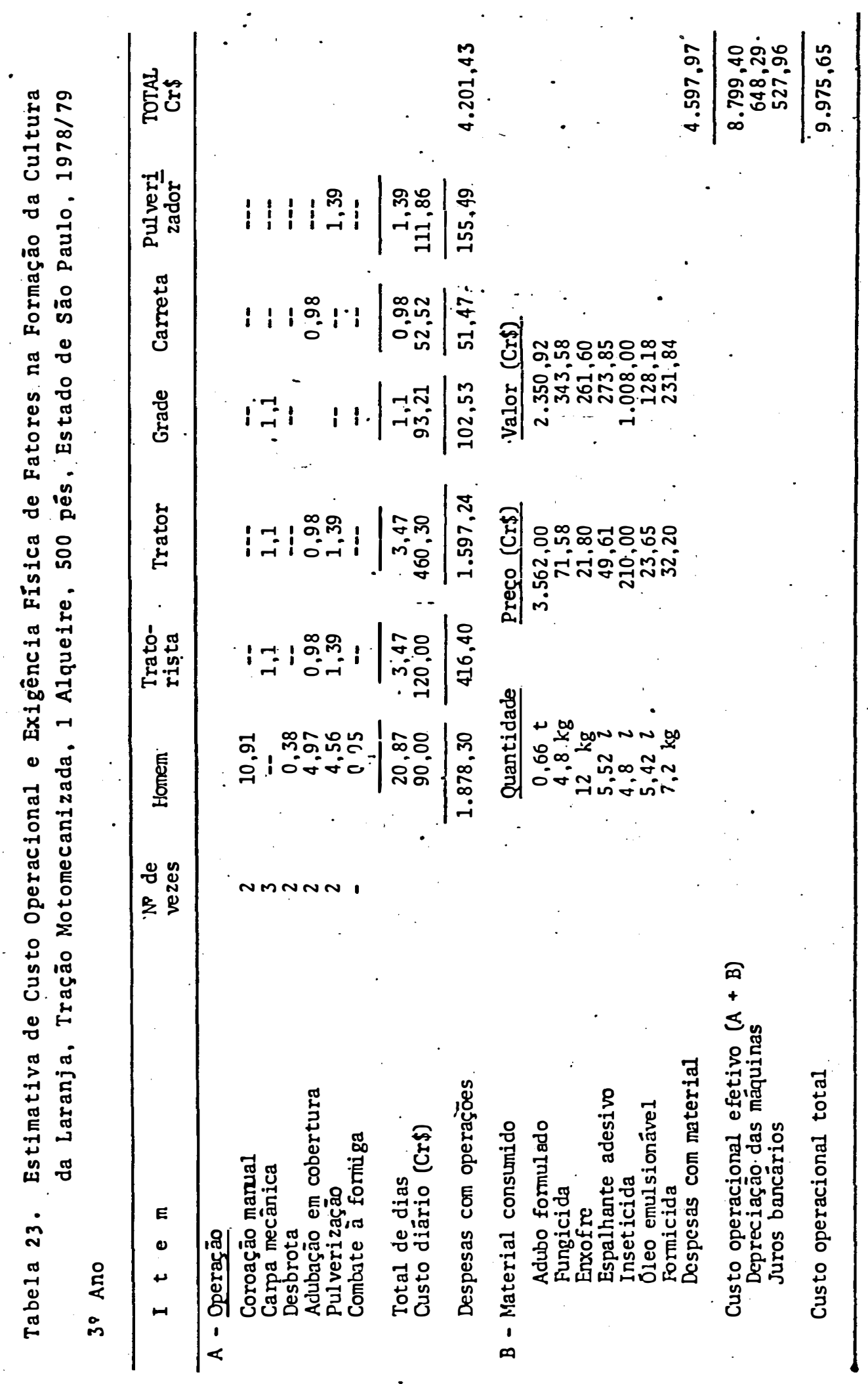




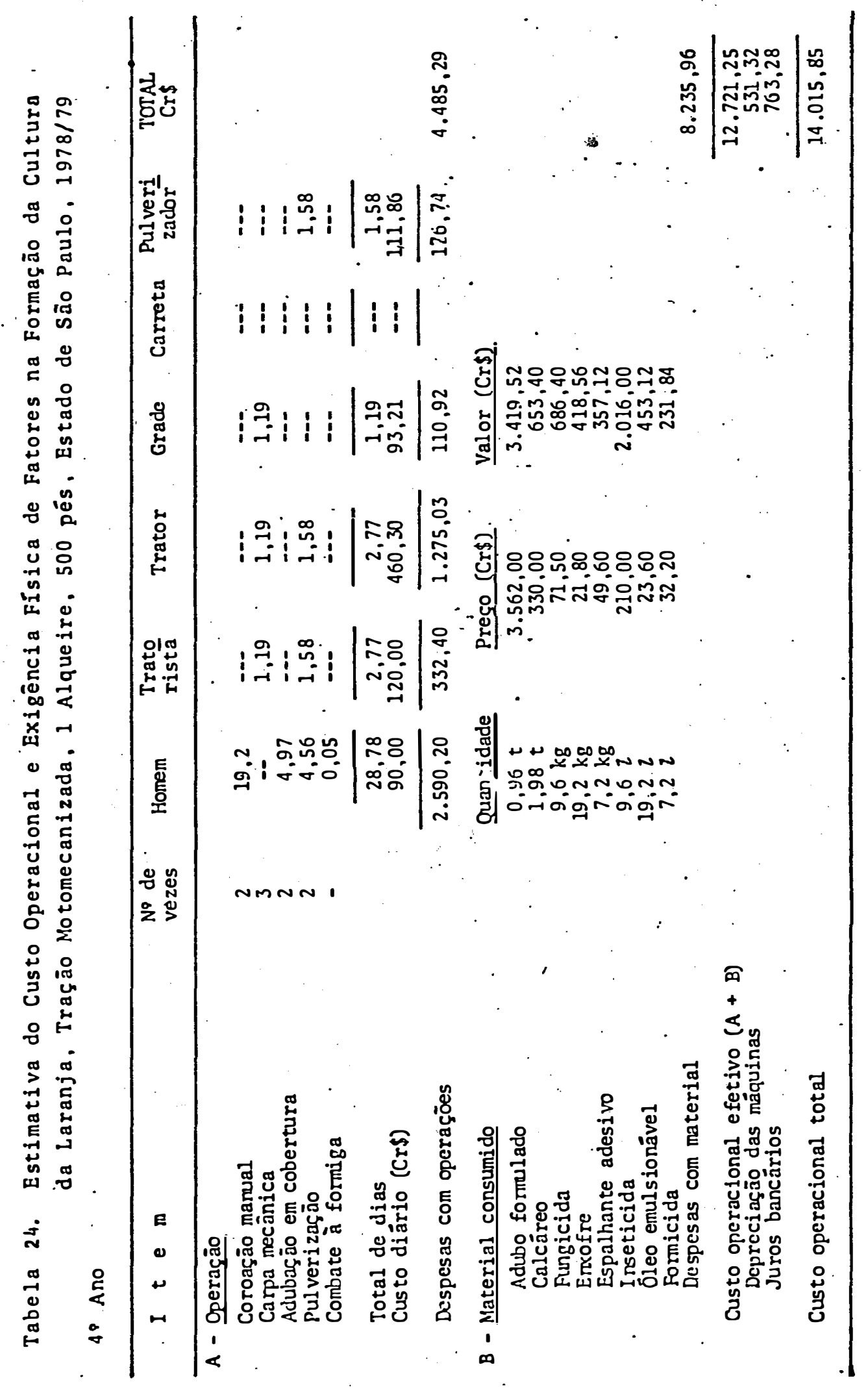

